\title{
An atlas of Mediterranean seismicity
}

\author{
GIANFRANCO VANNUCCI $\left({ }^{1}\right)$, SILVIA PONDRELLI $\left({ }^{1}\right)$, ANDREA ARGNANI $\left({ }^{2}\right)$, \\ ANDREA MORELLI $\left({ }^{1}\right)$, PAOLO GASPERINI $\left({ }^{3}\right)$ and ENZO BOSCHI $\left(^{3}\right)$ \\ ( $\left.{ }^{1}\right)$ Istituto Nazionale di Geofisica e Vulcanologia, Bologna, Italy \\ (2) Geologia Marina, ISMAR-CNR, Bologna, Italy \\ (3) Dipartimento di Fisica, Università degli Studi di Bologna, Italy
}

We present a description of the characteristics of the seismic deformation occurring in the Alpine Mediterranean Belt, and outline its association with tectonic and geologic features. We map seismic activity using several catalogues. Hypocentral data are retrieved from the Catalog of the International Seismological Center, the most comprehensive compilation of global data. Earthquake size and source geometry are instead evaluated from catalogs of earthquake mechanisms. These include seismic moment tensor catalogs (mainly the Harvard CMT Catalog, the Euro-Mediterranean Regional Centroid-Moment Tensors - RCMT Catalog and the regional moment tensor determination in the European-Mediterranean area - ETH Catalog) and a recent extensive compilation of solutions available in literature (EMMA) that provides consistency-controlled fault-plane solutions where mechanisms based on waveform fitting are missing. The study area follows the Africa-Eurasia margin from the Central Atlantic to Iran, and it has been divided into several provinces for the sake of presentation and graphic purposes. For each province, a brief geologic and tectonic description complements the outline of the pattern of seismicity, illustrated by several maps. Focal mechanisms are also grouped together to yield average mechanisms and enable synoptic views. A com prehensive bibliography is referenced. A CD-ROM accompanying this issue contains, besides maps, figures and results of local comparisons and summation of moment tensors with easy access via sensible maps, also an updated version of the EMMA focal mechanism database. Rather than an attempt at presenting a comprehensive seismotectonic model of the Mediterranean, this contribution aims to offer a panoramic view of the active tectonics as imaged by seismicity and focal mechanisms. Its scope may be seen as similar to that of an atlas, as a broad reference and a support for more specific studies.

\section{INTRODUCTION}

The Mediterranean region occupies the westernmost portion of the Alpine-Himalayan orogenic belt, and originated from the interaction among Eurasian, African and Arabian plates. This region is seismically very active, and is currently undergoing rather rapid deformation. Although the large-scale geodynamic regime is dominated by the $100 \mathrm{Myr}$ long convergent motion between Africa and Eurasia, the regional-scale kinematics reveals a very complex pattern, where contrasting tectonic styles - compressive, extensional, strike-slip regimes - coexist in close association. Subduction occurs next to back-arc extensional basins in the Calabrian-Tyrrhenian and Hellenic-Aegean systems. Transcurrent motion along the Northern and Eastern Anatolian faults marks the escape of the Anatolian block towards the west.

Seismicity is widespread in the region, although it is not restricted to narrow seismogenic boundaries, but is generally rather diffuse. Typically, maximum magnitudes are moderate but large earthquakes also take place. Earthquakes do pose a high hazard and risk in this region because of high density population, and historically they have been responsible for large losses in terms of human lives and property. 
The tectonic complexity of the Mediterranean is hard to figure out in its wholeness. However, recently increased and improved seismic catalogs now permit us to reveal and map, with unprecedented reliability and detail, the brittle deformation taking place in the lithosphere in this region. This possibility is ultimately a result of improved seismographic monitoring - with more and better instruments openly available to the whole scientific community - and developments in modeling techniques. We merged the most recent data with all existing information, based on instrumental observation, available in the literature on seismic source locations and properties, and examined the whole set with the goal of providing the best current picture of the seismic deformation in the region.

For our purposes, the best source of hypocentral parameters - coordinates of the foci, and magnitudes - is the Catalog of the International Seismological Center (ISC, 2004) that collects and reprocesses in a consistent way arrival time data from virtually all seismological institutions. The ISC dataset covers years from 1904 to 2002, although from 1904 to 1964 hypocentral parameters are less reliable and less continuous.

The most reliable information on source geometry is provided by Centroid-Moment Tensors (CMT), that are based on fitting long period seismic waveforms recorded at global scale (Dziewonski et al., 1981, 2000; and references therein). The CMT Catalog maintained at Harvard University includes data for worldwide earthquakes which have occurred with $M \geq 5.5$ since 1977 and can also be found at http://seismology.harvard.edu. The need for high-quality digital long period seismograms limits the applicability of the method to earlier times and to earthquakes with a small magnitude (lower than 5.5) to be globally recorded with a good signal-to-noise ratio. To overcome this limitation, a modification of the CMT scheme uses surface waves with intermediate period recorded at regional distance - the Regional Centroid-Moment Tensor (RCMT) - and can model earthquakes with magnitude as small as 4.2 (Arvidsson and Ekström, 1998; Ekström et al., 1998). The RCMT Catalog for the European and Mediterranean region is maintained at INGV as a joint project with Harvard University (Pondrelli et al., 2002, 2004a; also available at http://www.ingv.it/seismoglo/RCMT). Seismic moment tensors from long period waveform fitting are also computed by the Eidgenössische Technische Hochschule (ETH) of Zürich (Braunmiller et al., 2002), available at http://seismo.ethz.ch/info/mt.html. Both INGV and ETH include earthquakes recorded by Mediterranean VBB stations with $M \geq 4.5$ starting from the years 1997 and 1999 respectively.

Other methods for computing source geometry that use short period waveform fitting (that we do not mention here for brevity), or even the much simpler quite commonly used fit of polarities of first motions, have been used in studies targeted at specific areas, seismic sequences or otherwise selected events. Quality of such determinations varies widely. Solutions based on a few data, even if well fit, are generally unreliable, whereas those based on a sound fit to a good distribution of observations may be quite valid. An extensive recently derived compilation of source mechanism data for the Mediterranean (EMMA, Vannucci and Gasperini, 2003) gathers, compares and validates all such information available in the literature and provides a reliable database for studies such as this. Details on the EMMA database are provided in this volume by Vannucci and Gasperini (2004) and the most recent version of the database is included in the CD-ROM accompanying this volume.

Fig. 1. Schematic geological map of the Mediterranean region. The major tectonic structures of the Alpine orogen, thrust (with barbs) and strike-slip faults, are represented in red, whereas extensional faults are in green (topographic elevation, also used in the following figures, taken from ETOPO-2 global dataset).

Fig. 2. Map of main toponyms and geological references. The structural map is the same as in fig. 1. NATF North Anatolian Transform Fault; EATF - East Anatolian Transform Fault; G. and L. Caucasus - Greater and Lesser Caucasus, respectively; Tal - Talesh; AS - Apsheron Sill; MZT - Main Zagros Thrust; GKF - Great Kavir Fault; DhsF - Deh Sir Fault; DSF - Dead Sea Fault; AsF - Ashgabat Fault; KF - Kefallinia Fault. 

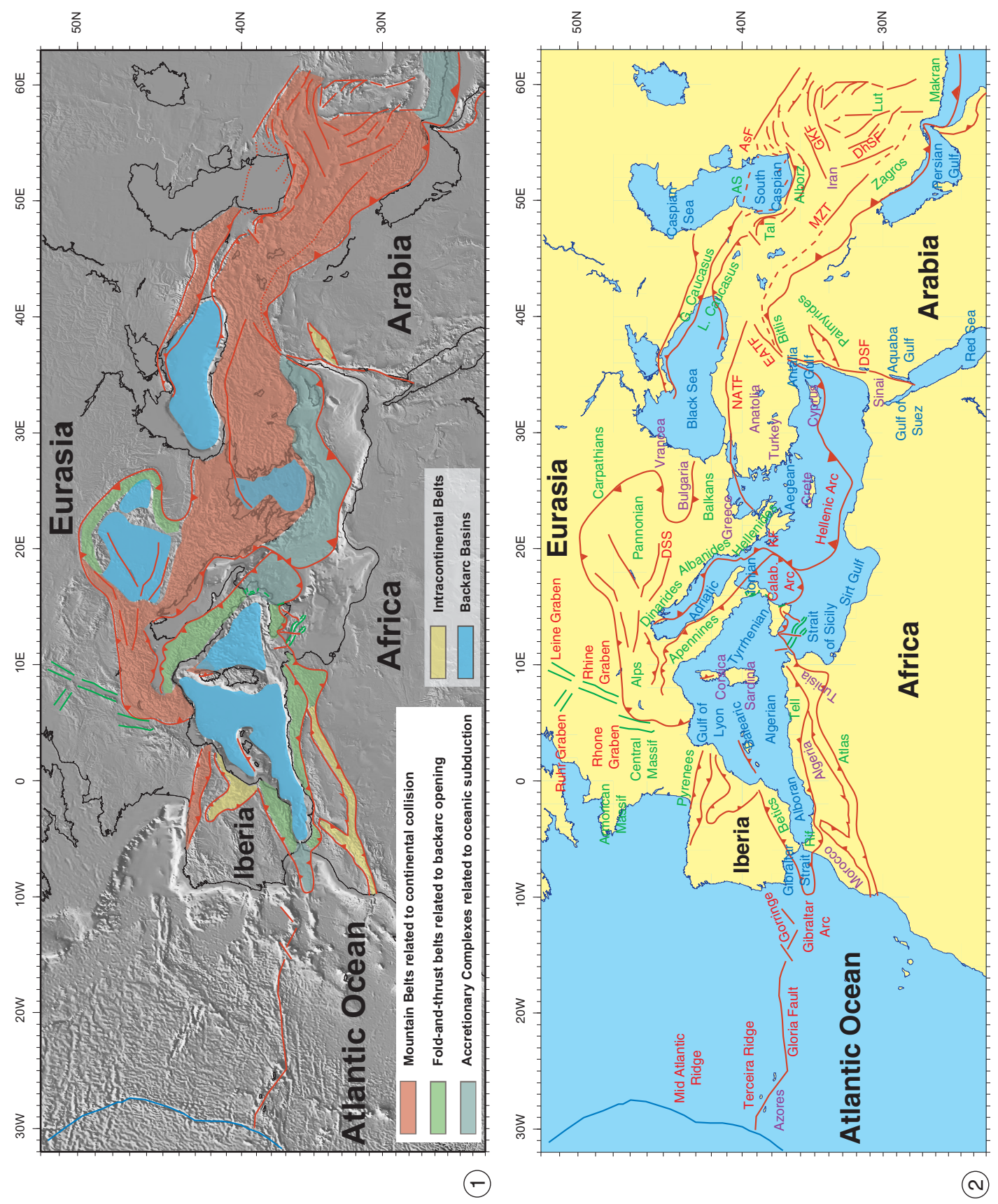
In the following sections, we will first describe the broad characters of the whole study area, extending in longitude from the Mid Atlantic Ridge to Iran, from the seismological and geological points of view (figs. 1 and 2). For the sake of description, the whole region was then divided into eight provinces. We consider them separately: for each province - generally rather extensive, and often including different tectonic styles - we present a seismotectonic view, and comment on the main geologic features. We emphasize that comprehensive geodynamic modelling of the region is beyond our scope - instead we restrict ourselves to an unprejudiced presentation of data, with the simple ambition of drawing a picture as it results from mining available databases. At the same time, we make the numerical data available (in the enclosed CD-ROM) to support specific studies.

\section{SEISMOLOGICAL FRAMEWORK}

In this region, seismicity is widely spread and rather frequent, as shown by fig. 3 where we plotted epicenters for all events with magnitude greater than 4.0 and focal depth shallower than $50 \mathrm{~km}$ which have occurred since 1904 and for which instrumental records exist (ISC, 2004). Some of the major earthquakes of the Mediterranean include the Gloria Fault 1941, $M_{s}=8.3$ event; the Atlantic Ocean, $M_{s}=8.0$, 1969, event; the Northern Africa El Asnam, 1980, $M_{w}=6.9$ shock; the Messina, Sicily, $1908 M_{s}=7.5$ earthquake; the Izmit, Turkey, 1999, $M_{w}=7.6$ event; the 1939, $M_{s}=8.0$, event at the easternmost tip of the North Anatolian Transform Fault; and the recent Bam, Iran, December 26, 2003, $M_{w}=6.6$ earthquake.

Shallow earthquakes mark the boundaries of the main plates involved in this geodynamic arena - Africa, Eurasia, and Arabia - and also identify smaller regions with little or no deformation, surrounded by broad seismic belts, suggesting, as we will show below, that there is more than just a three-plate game. Seismic events are however not uniformly distributed along these boundaries. The largest clusters are located along the Hellenides and around the Aegean, as well as along the Zagros, while other segments of the boundaries are seismically less active, such as the Tunisian part of Northern Africa or the Gloria Fault leg of the boundary between the Mid Atlantic Ridge and Gibraltar Strait (fig. 3).

Seismicity can be followed through the whole area, as it describes a rather convoluted active belt (fig. 3 ). At the westernmost edge of our region, the Mid Atlantic Ridge is marked by a narrow seismic band, whereas seismicity becomes more diffuse as we get closer to the Gibraltar Arc. Within the Mediterranean, earthquakes do not define a very sharp plate boundary, but rather outline a broad deforming zone. A kind of plate-boundary seismicity can however be followed along Northern Africa and Sicily, turning around the Tyrrhenian Basin along the Calabrian Arc and Apennines, and passing to the Alps to continue into the Dinarides - Hellenides, Hellenic Arc and Zagros. Complex tectonic patterns are also outlined within the seismic belt, particularly in the Aegean province, Anatolia, Caucasus and Iran. Seismicity is also associated with the Dead Sea Fault system (DSF), bordering to the west the Arabian plate, the Pyrenees and the tightest part of the Carpathian arc.

The presence of events occurring at depths greater than $50 \mathrm{~km}$ (fig. 4) identify some regions that are - or have recently been - connected to lithospheric subduction. The widest and longest descending slab is the one connected to the Hellenic Arc, dipping northeast beneath the Aegean Basin. It is clearly imaged by seismic tomography to reach the lower mantle (de Jonge et al., 1994; Bijwaard and Spakman, 2000; Piromallo and Morelli, 2003), but it is marked by earthquakes only down to a depth of about $200 \mathrm{~km}$. Conversely, in the Southern Tyrrhenian, seismic events are distributed along a Benioff zone spanning the whole upper mantle - down to about $600 \mathrm{~km}$ - and mark the subducted slab throughout its length (Piromallo and Morelli, 2003). A tight cluster of intermediate-depth earthquakes marks the Vrancea region, in the Carpathians, possibly a remnant of a now extinct subduction process. Something similar also happens beneath Southern Spain, but with more sporadic large and deep earthquakes. Subcrustal seismicity can also be found near the Gibraltar Arc, Cyprus and Zagros, in areas of continental collision. 


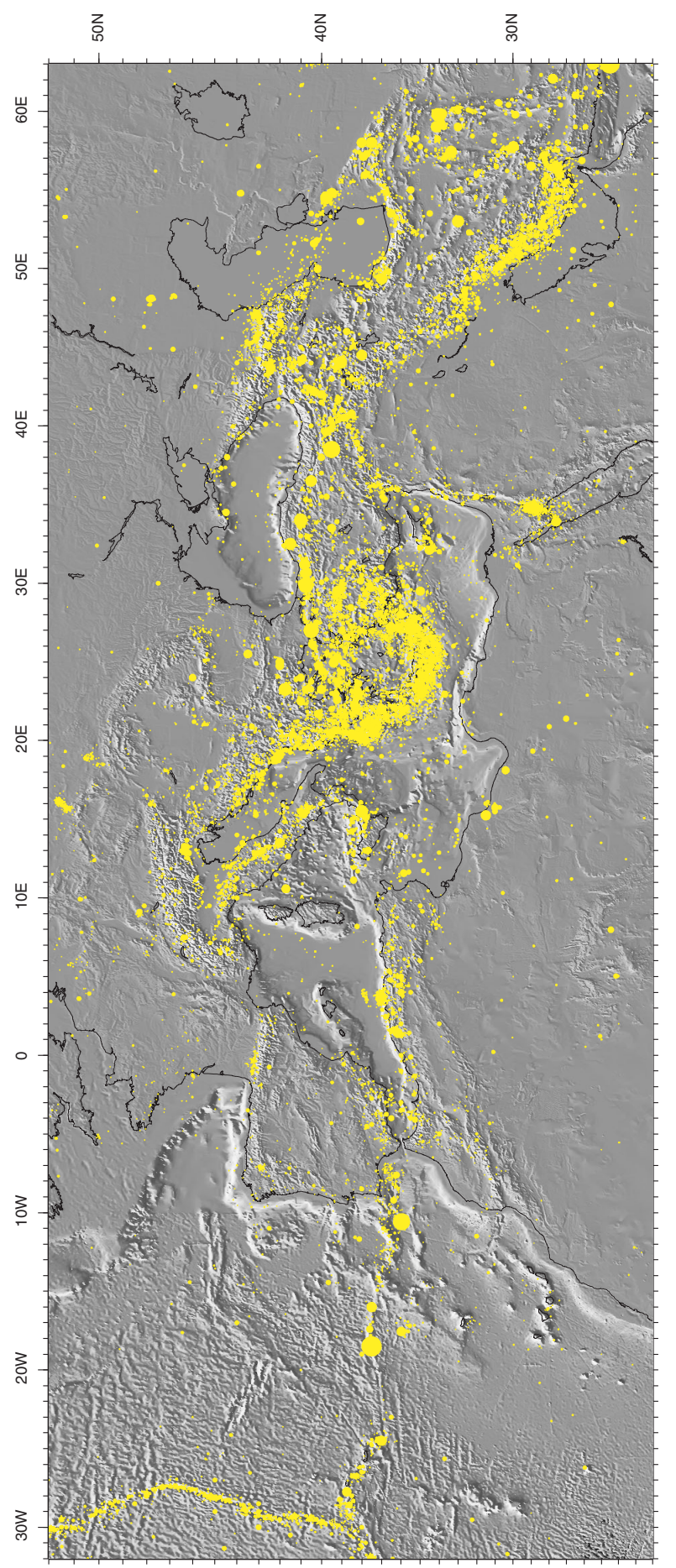

$\stackrel{5}{8}$

Ð艹

$\stackrel{\infty}{\Xi}$

苟诘

혼

产焉

吾

乙。

宊

is

들

跑

崖怘:

ర大

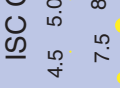

웅 


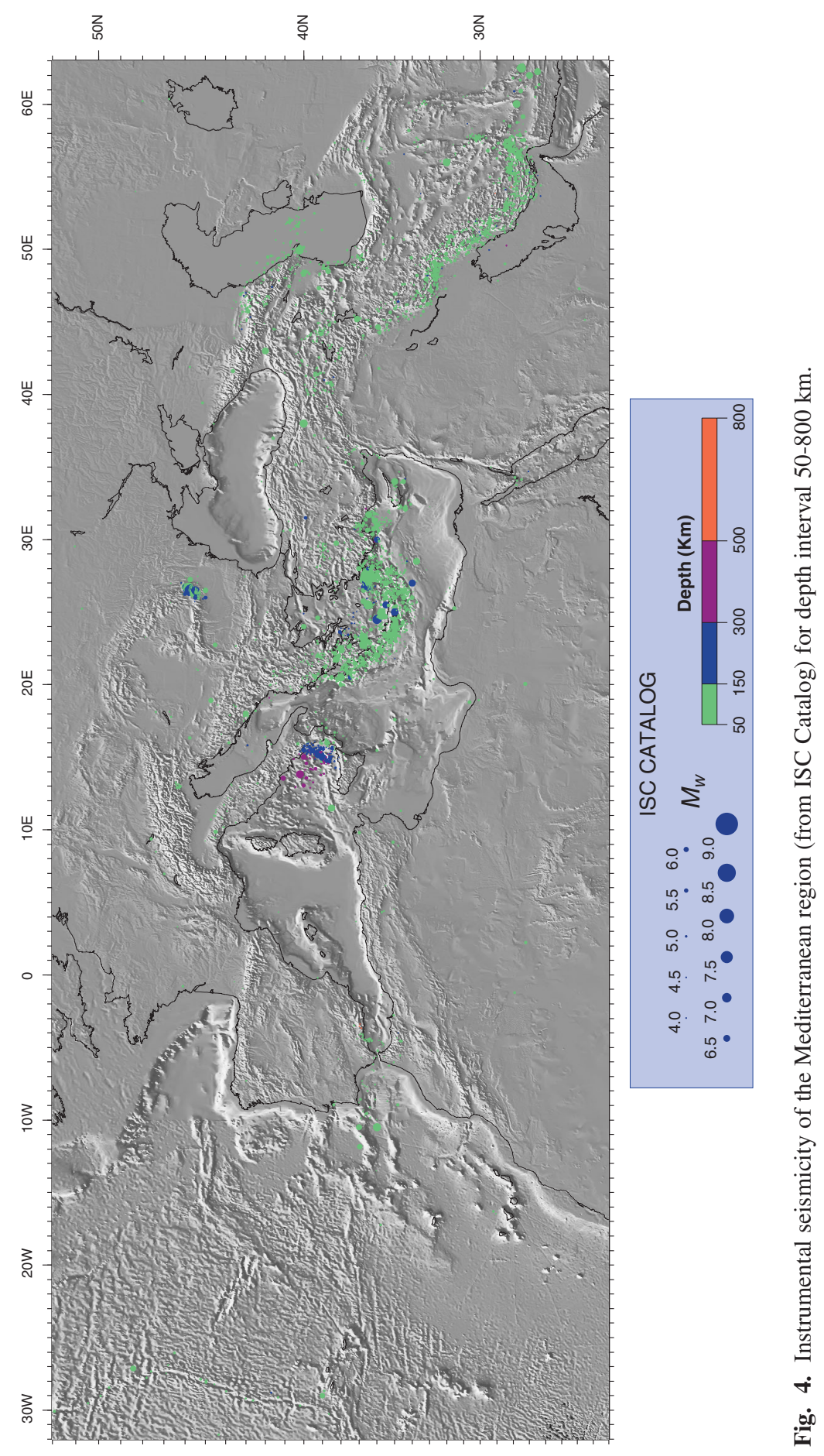




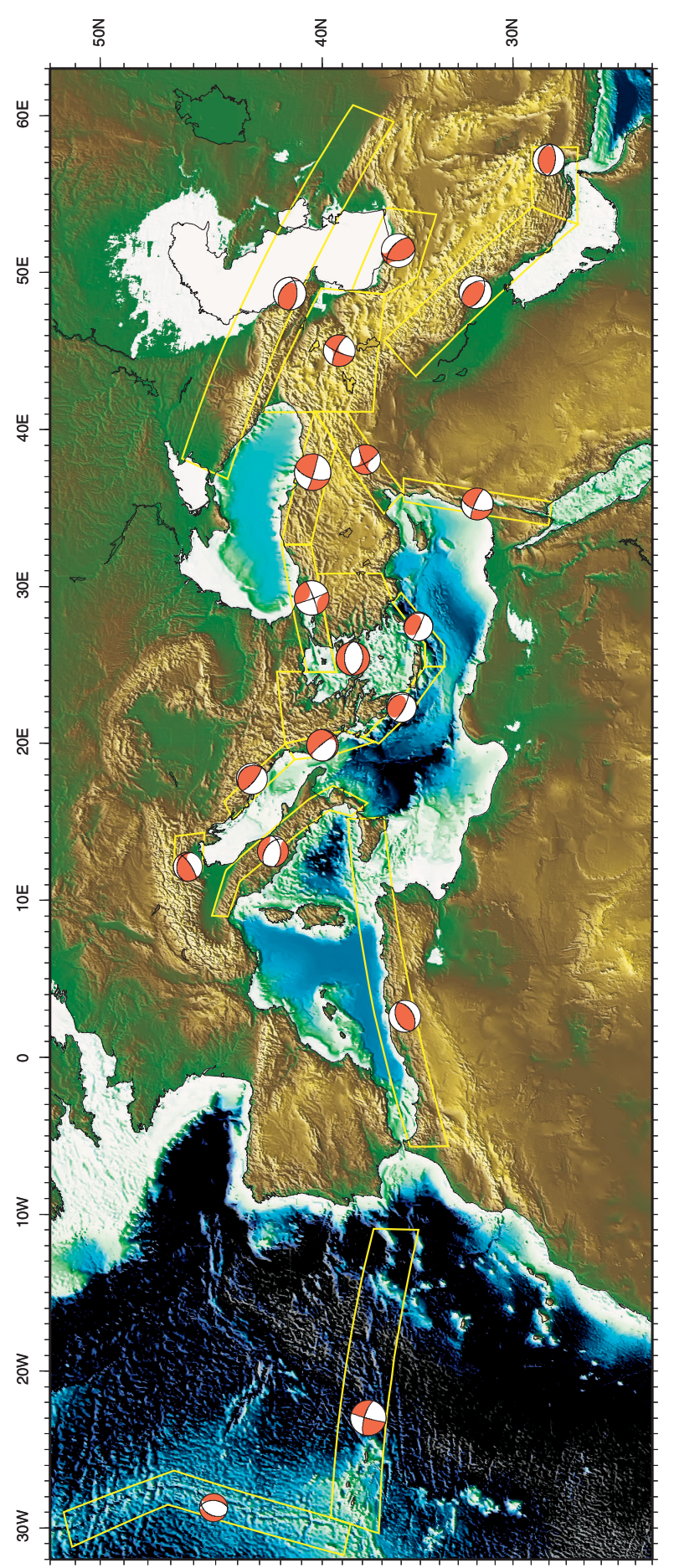

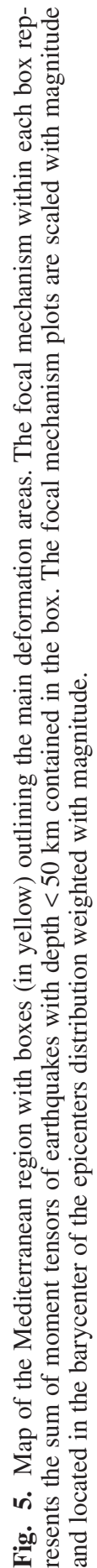




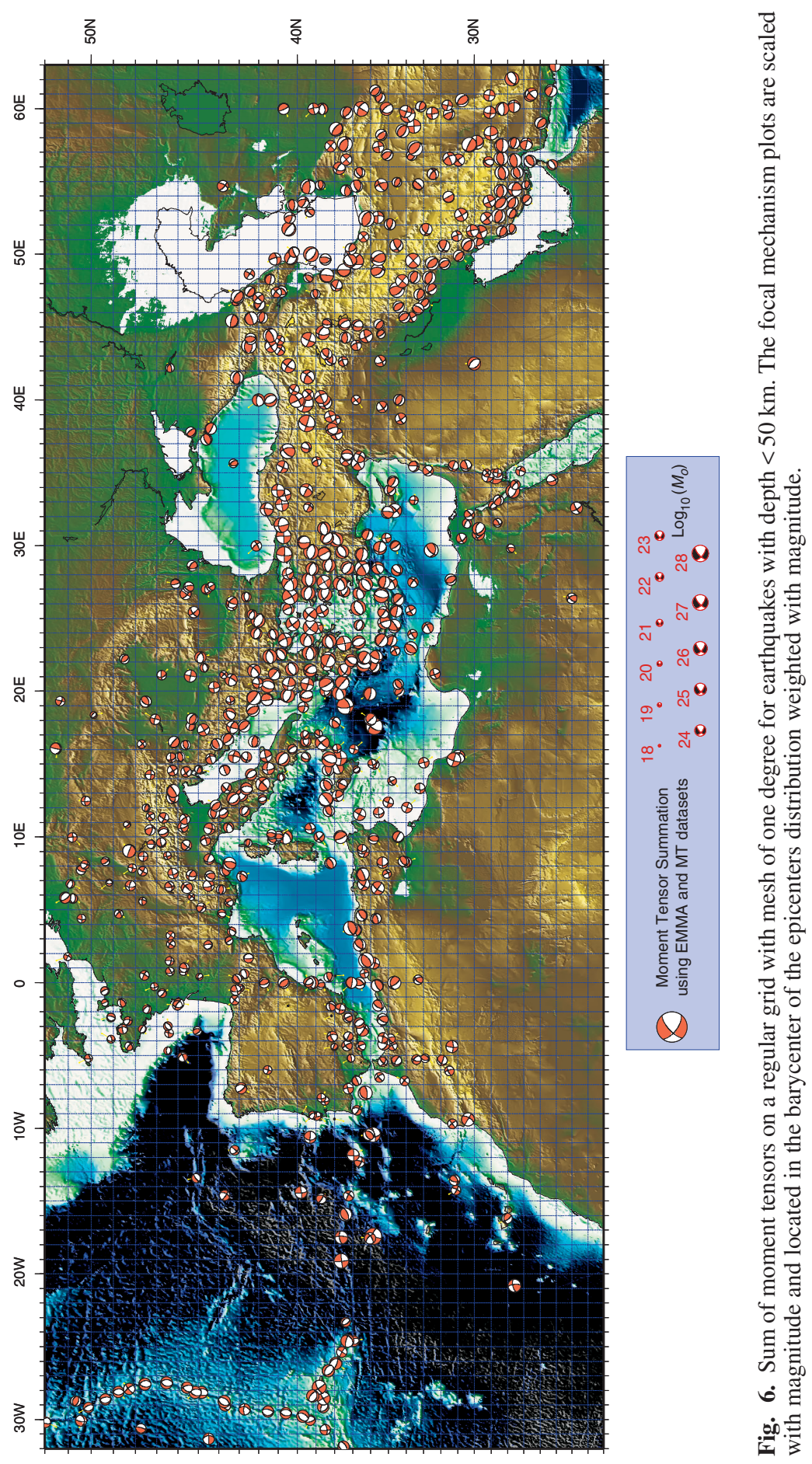




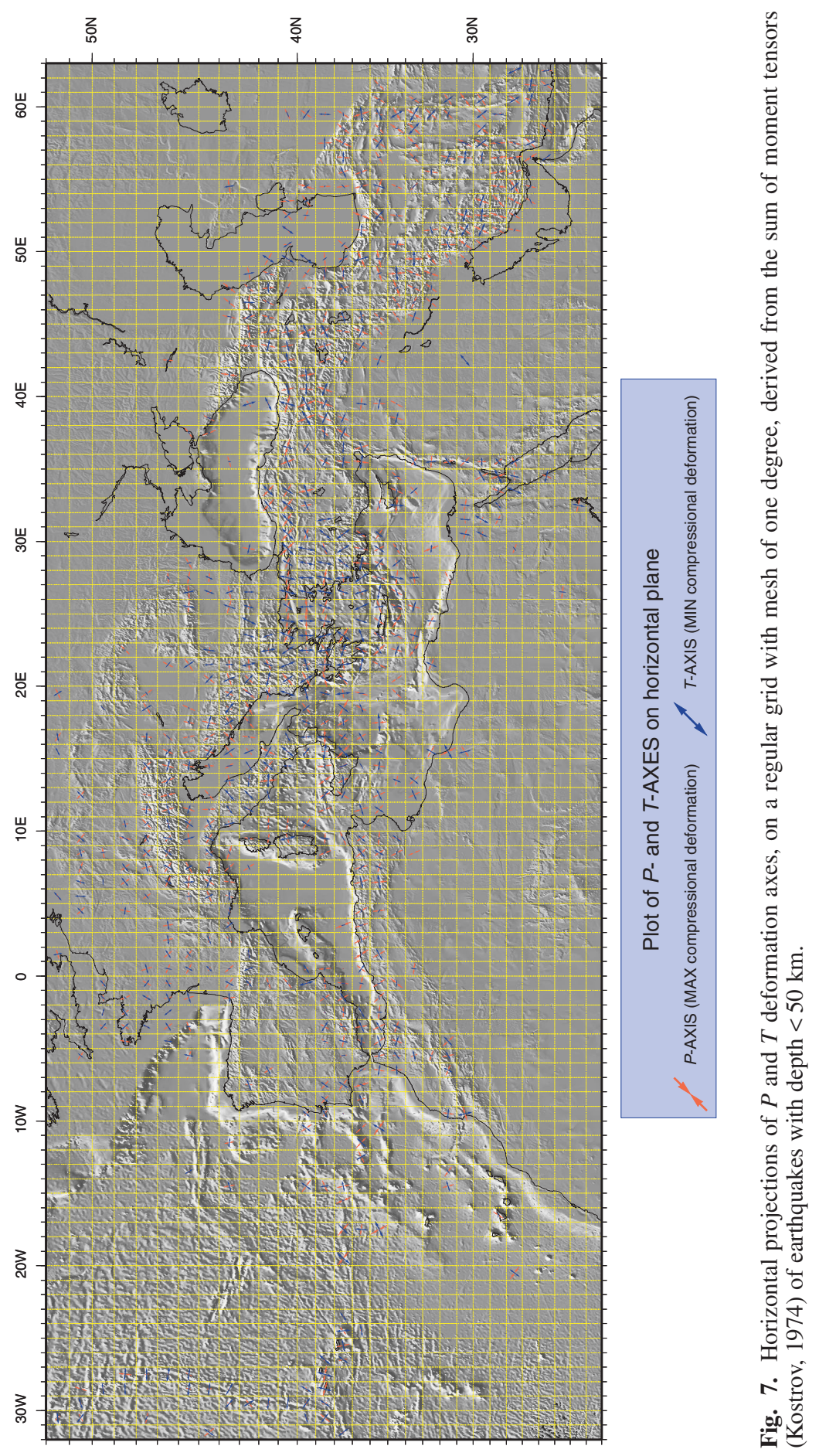


Ample availability of focal mechanisms (Harvard CMT and INGV RCMT catalogs, and the EMMA database) permits us to derive a summary description of seismic deformation to be used to gain information on the active tectonics of this region. Kostrov (1974) demonstrated that the contribution of each earthquake $k$ to the average strain tensor $\varepsilon$ within a rock volume $V$ is proportional to the moment tensor $M_{i j}$, so that the average strain induced by earthquakes is given by

$$
\bar{\varepsilon}_{i j}=\frac{1}{2 \mu V} \sum_{k=1}^{N} M_{i j}^{k}
$$

where $\mu$ is the shear modulus, and the sum is taken for the $N$ earthquakes located within the volume. This is the basic equation of the moment tensor summation method characterizing the seismic deformation style of a seismic source area on the basis of focal mechanisms. The results of these computations can be mapped either in terms of cumulative moment - using the usual conventions, i.e. focal spheres - or strain tensor eigenvectors - plotting arrows indicating the horizontal projection of maximum compression $(P)$ and tension $(T)$ axes. The sum of earthquake moment tensors located within a certain region therefore represents a way to map and summarize the average kinematic properties of that region (Jackson and McKenzie, 1988; Ekström and England, 1989; Westaway, 1992; Pondrelli et al., 1995; Viti et al., 2001). We applied this moment tensor summation technique to characterize seismogenetic areas at different spatial scales. For this purpose we constructed seismotectonically homogeneous boxes, on the basis of the observed seismicity (fig. 5). The resulting average moment tensors give a synoptic view of the large-scale seismic deformation pattern.

The extension that characterizes the Middle Atlantic Ridge (fig. 5) passes to strike-slip towards Gibraltar, along the E-W plate boundary, and finally to compression where the convergent plate motion between Africa and Eurasia prevails. Extension is active along the Apennines and in the Aegean region, and coexists with adjacent compression that runs throughout the eastern coast of the Adriatic Sea up to the Hellenic Trench. Further to the east, strike-slip deformation is dominant along the western and northern boundaries of the Arabian plate and in Anatolia. Compressional deformation again becomes predominant in the easternmost zones, extending from the Greater Caucasus to the Zagros (fig. 5).

The details of this gross picture are better described by the maps where moment tensor summation has been performed over a regular grid with a $1^{\circ} \times 1^{\circ}$ mesh (figs. 6 and 7). In fact, deviations from the regional trend along seismogenic zones are in this way depicted without any bias introduced by the arbitrary choice of the size and extent of the boxes. In each cell, the equivalent focal sphere is located at the barycenter of the epicenter distribution, weighted with magnitude, and its size is scaled with its cumulative scalar moment.

In the following part of the paper we present some more detailed pictures of the seismic deformation, discussing its relationships with tectonics. For this purpose, the Mediterranean region has been subdivided into eight provinces which are analyzed separately. Moreover, additional plots and information are provided in the enclosed CD-ROM.

\section{GEOlOGicAl FRAMEWORK}

The Mediterranean region offers a large variety of geological examples, in a wide range of scales, on the theme of continental collision (fig. 1; Dewey and Bird, 1970; Burchfiel and Royden, 1991; Royden, 1993a). The complex morphology of the Mediterranean region, characterised by deep basins and looping mountain belts, has originated from the long-lasting plate convergence between Africa/Arabia and Eurasia (Dewey et al., 1973, 1989; Horvath and Berckhemer, 1982; Dewey, 1988; Le Pichon et al., 1988; Royden and Burchfiel, 1989; Mantovani et al., 2002). This plate convergence has been active since the 
Late Cretaceous with rates that typically increased eastwards, as the poles of relative rotation were mainly located in the Atlantic region.

Continental collision in the Mediterranean region has occurred since the Eocene (Coward and Dietrich, 1986; Schmid et al., 1996), following the early subduction of oceanic lithosphere. The continental margin of the southern plate was quite articulated and in particular was characterised by the occurrence of two pronounced promontories: Adria and Arabia (Şengör, 1976; Channell et al., 1979). These two promontories were the first to collide with Eurasia, giving rise to the highest mountains of the Mediterranean region, i.e. the Alps and Caucasus. Both the neotectonics of the Mediterranean region and the distribution of seismicity outline the Adriatic and Arabian promontories (McKenzie, 1972), and the role played by the irregular southern continental margin during the whole Alpine evolution has been highly relevant.

Moreover, the average elevation and the width of high plateaus within the Tethyside orogen increase eastward, showing a relationship with convergence rates (Ben Avram and Nur, 1976). In fact, moving from west to east, we pass from the Mediterranean backarc basins (Horvath and Berckhemer, 1982; Rehault et al., 1984; Faccenna et al., 2001) to the Turkish and Iranian plateaus (Şengör and Kidd, 1979), progressively higher on average. In a very simplified way, the Mediterranean region records, from west to east, a passage from a simple deformation at the oceanic plate boundaries of the Atlantic, characterized by narrow seismic belts, to a broad belt of seismicity and deformation that characterizes the continental collision setting (McKenzie, 1972; England and Jackson, 1989). Among the several possible reasons for this seismological and tectonic behavior, the weaker rheology of the continental lithosphere and the role of pre-existing faults or weakness zones seem to be the chief ones (McKenzie, 1977).

Several tectonic processes, besides plate convergence-driven oceanic subduction and continental collision, have contributed to shape the present Mediterranean Alpine orogen, mostly because of along strike variability of lithospheric nature and convergence rates. Chief among them are passive sinking and rollback of the subducted lithosphere, leading to backarc basin opening (Dewey, 1980), and tectonic escape of continental blocks away from boundaries of collisional indentation (Burke and Şengör, 1986). In addition, where continental collision is more pronounced, as in the Iranian region, a process of plateau build up seems to operate as a result of collisional tightening (fig. 1; Şengör and Kidd, 1979; Şengör et al., 2003; Allen et al., 2004). It has also been suggested that, in some cases, the lithospheric root of thick orogens can detach and drop into the mantle, possibly carrying along part of the lower crust (Houseman et al., 1981; Dewey, 1988). This process can trigger an extensional collapse of the orogen and promote anorogenic volcanic activity, and has been considered applicable to the Alboran Basin (Platt and Visser, 1989; Visser et al., 1995), although other authors have offered different interpretations (Gutscher et al., 2002; Faccenna et al., 2004). It also appears that where continental collision has occurred, a significant role is played by rigid blocks wrapped around by deformation zones, such as Black Sea and South Caspian, possibly floored by old oceanic crust, and the Lut Block which has a continental crust (fig. 1).

Subductive margins can be followed throughout the Mediterranean region and towards Iran, bounding a broad region of deformation, on average wider to the east, defined as the Alpine Belt s.l. (Dewey et al., 1973).

The large extensional basins of the Mediterranean region (Alboran, Algero-Balearic, Tyrrhenian, Pannonian, Aegean) formed as backarc basins on the wake of the retreating subductive boundary (fig. 2; Horvath and Berkhemer, 1982; Rehault et al., 1984; Malinverno and Ryan, 1986; Royden, 1988, 1993b; Faccenna et al., 2001). Most of these basins are floored by thinned continental crust, although the occurrence of oceanic crust in the Algero-Balearic Basin has been inferred from Expanding Spread Profiles (de Voogd et al., 1991; Pascal et al., 1993). Mid Ocean Ridge basalts have also been sampled in the Southern Tyrrhenian Sea (Kastens et al., 1988); however, as these rocks come from ridges on the sea floor, they may just represent intrusions of Mid Ocean Ridge basalts into a highly thinned continental crust (Argnani and Savelli, 2001). The subducting and retreating lithosphere in all but one case (Pannonian Basin) belongs to the African plate. 
An interesting aspect of the Mediterranean Alpine orogen concerns the polarity of the main subduction boundary which alternates along strike (Dewey et al., 1973). The African plate is subducted northward in the belt that stretches from North Africa to the Apennines, whereas the European plate is subducted southwards under the Alps and the Carpathians. Africa is again the subducted plate along the Dinarides and Hellenic Arc and subduction from the south continues in the Bitlis and Zagros, where Ara-

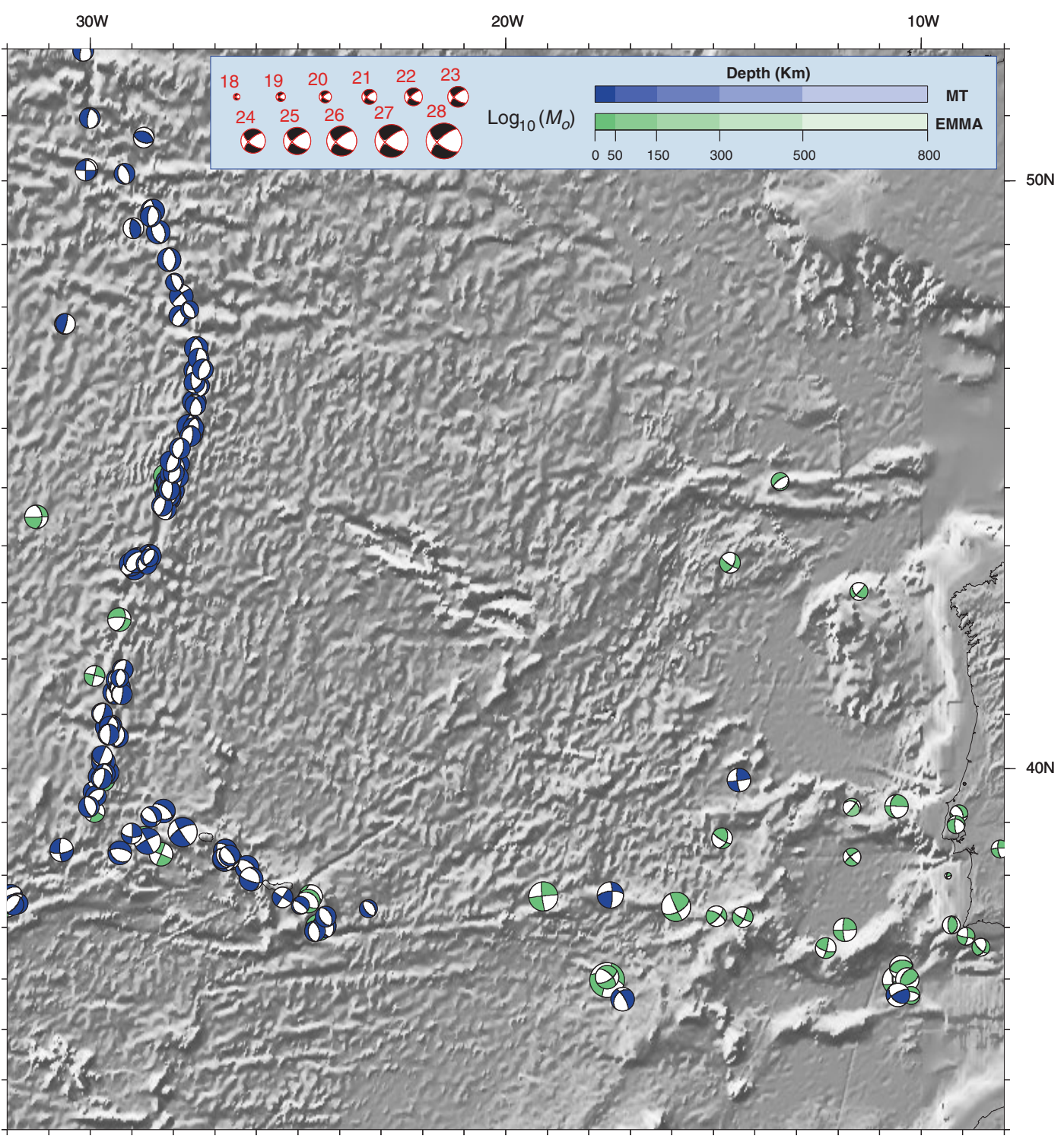

Fig. 8. Atlantic province. Focal mechanisms of earthquakes from MT catalogs (blue) and EMMA database (green). 
bia is subducted northward. During plate convergence these segments of alternate polarity had different extent and relative position, greatly influencing the long term geological evolution of the Mediterranean region (e.g., Argnani, 2002; Argnani and Piromallo, 2003).

\section{The Atlantic Province}

In the Mid Atlantic, seismicity is concentrated in a narrow band along the ridge, here roughly trending N-S (fig. 3). Largest earthquakes have generally moderate magnitude, mostly between 4 and 5.5, with few events with magnitude greater than 6.0. The tectonic pattern outlined by the focal mechanisms appears rather simple: divergent motion along the ridge is well depicted by extensional mechanisms, with few strike-slip events (fig. 8). The summary moment tensor, calculated for this whole segment of the ridge, also shows that extensional deformation dominates (figs. 5 to 7). The $T$-axis trends NW-SE, consistent with opening direction of the North Atlantic Ocean (DeMets et al., 1994).

The Atlantic ridge has a ridge-ridge-transform triple junction near the Azores Islands (Searle, 1980; Madeira and Ribeiro, 1990). Near the triple junction, the transform is leaky and presents an extensional component, which is partly responsible for the origin of the Azores volcanic islands. In fact, earthquake focal mechanisms are mainly extensional close to the Azores archipelago (fig. 8). The border between the African and Eurasian plates branches to the east from this triple junction, directing towards Gibraltar and the Mediterranean. The E-W structure evolves to a right-lateral transform fault, named the Gloria Fault, that connects the simple extensional regime of the mid-ocean ridge to the more complex deformation of the Gibraltar region. The central part of the Gloria Fault appears to be seismically silent, at least for moderate to large magnitude events, excluding the isolated example of the $1941, M_{s}=8.3$ event (fig. 3 ). The seismicity that occurs in the eastern segment of the Gloria Fault is more sparse and is characterized by a dominant right-lateral strike-slip (fig. 8). Largest magnitudes are moderate to large, up to the $M_{s}=8.0$, February 28, 1969 event (fig. 3). Close to the Gibraltar Strait, the deformation is slightly more diffuse and focal mechanisms also show some compressional events, with direction of compressional axes in agreement with Africa-Europe convergence vectors (fig. 8). Thrust mechanisms and NE-SW-trending push up structures, also involving the oceanic lithosphere (i.e. the Gorringe Bank), have been reported in this region (Sartori et al., 1994; Hayward et al., 1999; Zitellini et al., 2004).

The seismic deformation on the whole region between the mid-Atlantic ridge and the Mediterranean shows a strike-slip geometry (figs. 5 to 7). It may be worth noting that as the boundary leaves the oceanic crust to enter into transitional to continental domains, the deformed region increases in size, events reach larger magnitudes, and focal mechanisms display a much larger variety of fault plane directions (figs. 3 and 8).

\section{The Western Mediterranean: Betics, Alboran and North Africa}

\subsection{Alboran Sea and surroundings}

Seismicity in the western part of the Mediterranean region follows the southern Iberia Peninsula, along the Betics, the Alboran Sea, and the coast and mountain ranges of Northern Africa (fig. 3). The Betics are a ENE-WSW-trending and N-verging fold and thrust belts located along the southern part of Iberia that originated when the Iberia continental margin became involved in the Alpine collision (Banks and Warburton, 1991; Blankenship, 1992). Towards the Gibraltar Strait, the structural trends turn to N-S. Deformation mainly occurred during the Miocene (Burdigalian to Tortonian) and palaeomagnetic data indicate that the external units show a remarkable clockwise rotation around vertical axes (Platt et al., 2003). Seismicity is highly frequent in the Betics, although largest magnitudes are usually low to moderate. Only rare events have a magnitude greater than 5.0 (fig. 3). Focal mecha- 


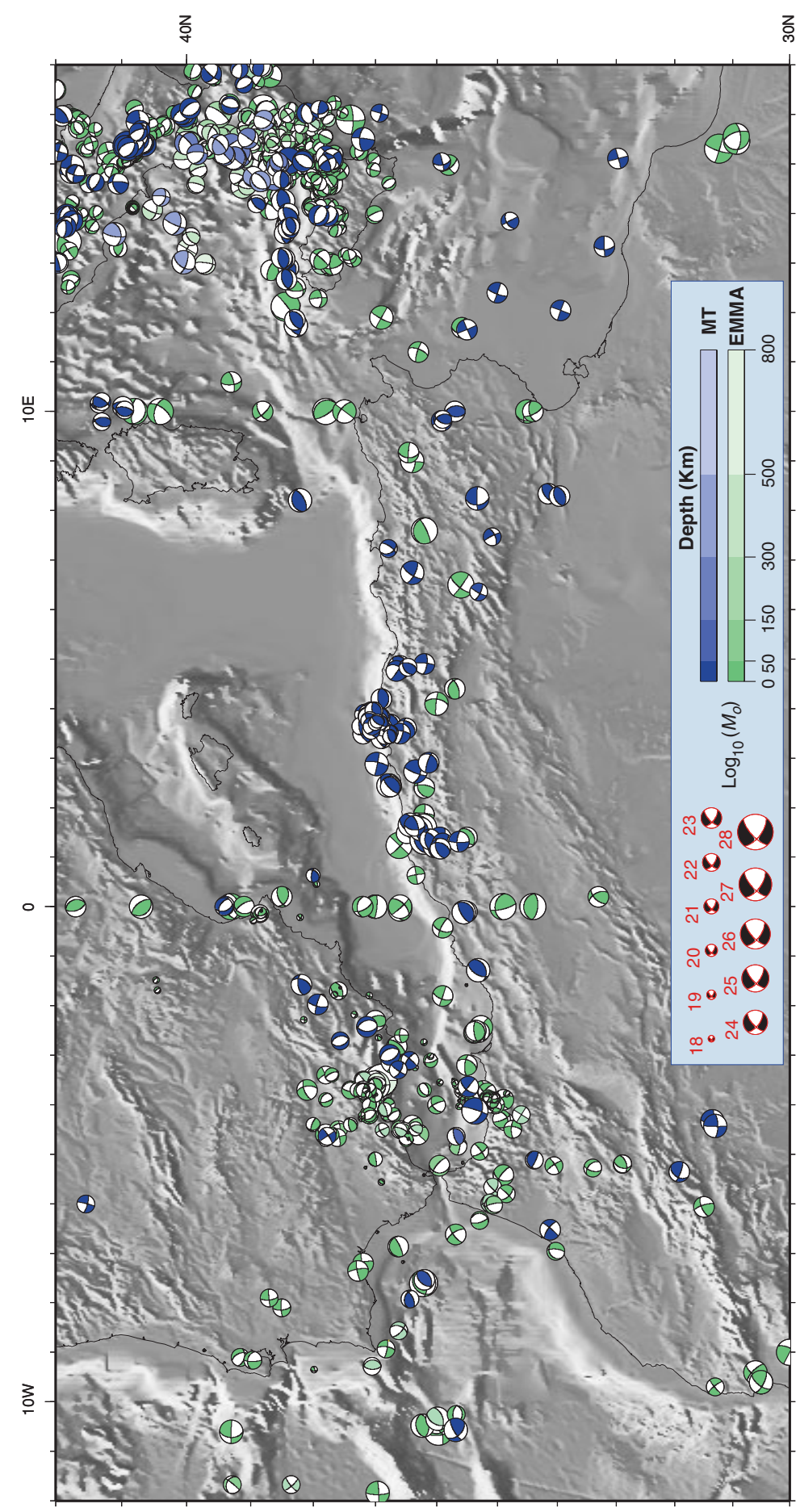

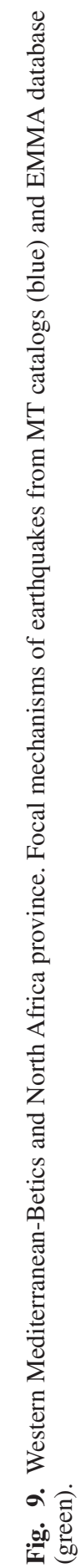


nisms show a rather large heterogeneity, with strike-slip and extensional events prevailing, but no clear pattern can be observed (fig. 9). This region is characterised by subcrustal earthquakes, typically shallower than $100 \mathrm{~km}$, but sometimes as deep as $600 \mathrm{~km}$ (fig. 4). The shallow events have moderate maximum magnitudes, whereas the deep events reach larger magnitude, up to 6.5 (figs. 3 and 4). This particular seismicity has been interpreted as related to a remnant lithospheric body, dipping in the mantle beneath the southern Iberia Peninsula (Blanco and Spakman, 1993; Piromallo and Morelli, 2003).

The Alboran Basin, opened mainly during the Miocene (Watts et al., 1993; Comas et al., 1999), and was subsequently affected by strike-slip deformation with fault directions compatible with the vector of Africa-Europe convergence (DeMets et al., 1994; Alvarez-Marron, 1999; Sella et al., 2002). Seismicity is characterized by small to moderate maximum magnitude events (fig. 3) that can be related to a prevailing strike-slip deformation occurring along NE-SW striking structures that cross the Alboran Basin (fig. 9). The substrate of the basin is composed by the same terranes cropping out in the internal part of the Rif and Betic ranges, i.e. the Alboran Domain. The crust underneath the Alboran Basin is about 12$20 \mathrm{~km}$ thick and thickens to 25-40 km underneath the adjacent Betic and Rif ranges (Geiss, 1987). Volcanism started in the Early Miocene with calc-alkaline character, to be replaced subsequently by transitional to alkaline products towards the Pliocene (Turner et al., 1999; Duggen et al., 2004). This change in magmatic character is thought to be related to either some form of lithospheric root removal (Turner et al., 1999) or westward slab rollback (Duggen et al., 2004).

The Gibraltar Arc represents the connection between the Rif and the Betic fold-and-thrust belts. The present day seismicity along the arc is scarce and of low magnitude (fig. 3). Focal mechanisms are mainly strike-slip and still related to the same tectonic structures that cross the Alboran Basin. The shape of the arc is strictly connected to the origin of the Alboran Basin, which has given rise to controversial interpretations that may be grouped within two main hypotheses: a) westward subductive retreat of oceanic lithosphere (Royden, 1993b; Lonergan and White, 1997; Gutscher et al., 2002; Faccenna et al., 2004); b) post-collision root detachment or removal, followed by orogen collapse (Platt and Vissers, 1989; Seber et al., 1996; Zeck, 1996). Nevertheless, in spite of the improving knowledge about tectonic evolution and lithospheric structures (Calvert et al., 2000; Platt et al., 2003), the geodynamics of the Alboran Basin and Gibraltar Arc still remain elusive and seismicity also fails to give a clear pattern of the present-day deformation system.

The Rif is a $S$-verging fold and thrust belt that runs along North Africa from the Gibraltar strait to Algeria (Wildi, 1983; Chalouan et al., 2001). Terranes characterised by basement units are located in the internal part of the Rif and are similar to the Betics internal units (Alboran Domain). They are believed to belong to a kind of microcontinent that stretched from Gibraltar to the Tyrrhenian region, and that was dismembered during the last stages of Alpine collision, from the Miocene onward (Alvarez, 1976). The external part of the belt is composed of a stack of Mesozoic-Tertiary passive margin and basin sediments mostly deformed throughout the Miocene, in the same way as the Betics. A large counter-clockwise rotation of the external units is supported by palaeomagnetic data (Platt et al., 2003). Seismicity in the Rif is quite frequent, also with large magnitude events (fig. 3), and it is characterised by strike-slip to thrust focal mechanisms with $P$-axes that generally agree with NW-SE Africa-Eurasia convergence (fig. 9). Strike-slip events occur on the NE-SW striking structures crossing the Alboran Sea, while thrust mechanisms are for earthquakes mainly occurring in the chain. The most recent earthquake occurred on February 24,2004 , reached $M_{w}=6.5$ and was followed by a seismic sequence that included several events with magnitude larger than 4.5. All events for which the focal geometry has been determined show strikeslip mechanisms.

The Rif continues to the east into the E-W-trending Tell, which follows the northern coast of Africa through Tunisia. Strong earthquakes occurred along this mountain range, such as the destructive $1980 \mathrm{El}$ Asnam earthquake $\left(M_{w}=6.9\right)$, and the most recent event of May 27, 2003 $\left(M_{w}=5.7\right)$. Focal mechanisms along this belt always show thrust geometry, sometimes with a small oblique component. $P$-axes consistently trend NW-SE, and are in agreement with Africa-Eurasia convergence (fig. 9; DeMets et al., 1994; Sella et al., 2002; McClusky et al., 2003). Terranes char- 
acterised by basement units (Alboran domain) are located in limited portions of the internal part of the Tell (Kabylian units). Stacked units of sediments belonging to the African passive margin and adjacent deep-water basin (Flysch units) represent the external Tell. These units were deformed from Early-Middle Miocene to Quaternary by S-SE-propagating thrusts.

The Rif and Tell mountain ranges record the Alpine subduction-to-collision evolution of the Western Mediterranean region (Wildi, 1983) and are a conspicuous part of the continuous belt of mountain ranges that runs throughout the Mediterranean, continuing further east towards the Himalaya. Throughout the Rif and Tell range, volcanism started in the Middle Miocene with calc-alkaline character, and was subsequently replaced by transitional to alkaline products towards the Pliocene (Maury et al., 2000). As for the Alboran Basin, this change in magmatic character has been related to slab breakoff.

South of the Rif and Tell, the Saharian Atlas is a high mountain range originated during the Cenozoic Alpine collision that affected the African craton (Piquet et al., 2002). As deformation occurred at some distance from the plate margin, the Atlas can be considered an intra-continental belt. Perhaps for this reason, seismic events are rare, sparse and with small magnitude (fig. 3). In the easternmost part, in East Algeria and Tunisia, seismicity is clustered along alignments striking ENE-WSW. Focal mechanisms are mainly strike-slip, but isolated thrusts are also present (fig. 9). Reactivation of favourably oriented inherited weakness zones, in particular a system of Mesozoic grabens, played a major role in the formation of this chain. In fact, palaeogeographic reconstructions outline the occurrence of a WSW-ENE-trending trough, that extended from Morocco to Tunisia during Early Jurassic, following a Triassic rifting. Transpressive reactivation occurred already in Middle-Late Jurassic, but the major deformation, that leads to the present mountain range, is of Cenozoic age and occurred in two major events, Late Eocene and Quaternary (Frizon de Lamotte et al., 2000). Shortening activity since Late Cretaceous, however, is also reported. Whether the Atlasic reverse faults and thrusts are mechanically linked to the Alpine boundary to the north, or rooted underneath the mountain range (true inversion tectonics), is still a matter of debate (Piquet et al., 2002). Shortening estimates for the Neogene across the Atlas range, however, account for $20-40 \%$ of Africa-Europe convergence, suggesting that the deformation of the Atlas played a major role in the plate boundary evolution (Gomez et al., 2000).

It might be of interest to note that in the Tell, the central segment of North Africa, focal mechanisms show a consistent pattern of compressional solutions, whereas when moving to the western and eastern sides of the belt, where changes in tectonic trends occur, focal mechanisms and seismicity present an increased variety of solutions, mostly strike-slip, and a broader spatial distribution, respectively (figs. 6, 7 and 9; Pondrelli, 1999). This pattern can be observed in the Rif-Alboran region, but it is particularly well expressed in Tunisia and toward Sicily, where the continuity of the Tell fold-and-thrust belt is interrupted by the extensional structures of the Strait of Sicily. However, the geometry of deformation of the entire North Africa-Sicily region is mainly compressional, as also confirmed by the summary moment tensor obtained for this region, that is a pure thrust, with a compressional $P$-axis trending to NW (fig. 5).

\subsection{Sicily and surroundings}

The Strait of Sicily, which interrupts the continuity of the Maghrebian fold-and-thrust belt between North Africa and Sicily, is characterised by a thinned crust (about $20 \mathrm{~km}$ ) and by a system of NW-SE-trending extensional troughs originated mainly during the Pliocene (Argnani, 1990). The three major troughs, Pantelleria, Malta and Linosa, are deeper than $1000 \mathrm{~m}$. Alkaline volcanic activity has been documented since Tortonian in the western part of the strait (Argnani and Torelli, 2001). Although most of the activity remained submarine, two volcanic islands, Pantelleria and Linosa, originated in the last 0.5 Ma. Seismicity is almost absent in the segment of fold-and-thrust belt that connects Tunisia to Sicily, and appears much reduced in the whole Strait of Sicily, when compared to the adjacent areas. Moderate magnitude seismicity is present in the Malta plateau and in the Sirt Gulf, on either side of the rifting (fig. 3). Focal mechanisms show consistently a strike-slip regime with $P$-ax- 


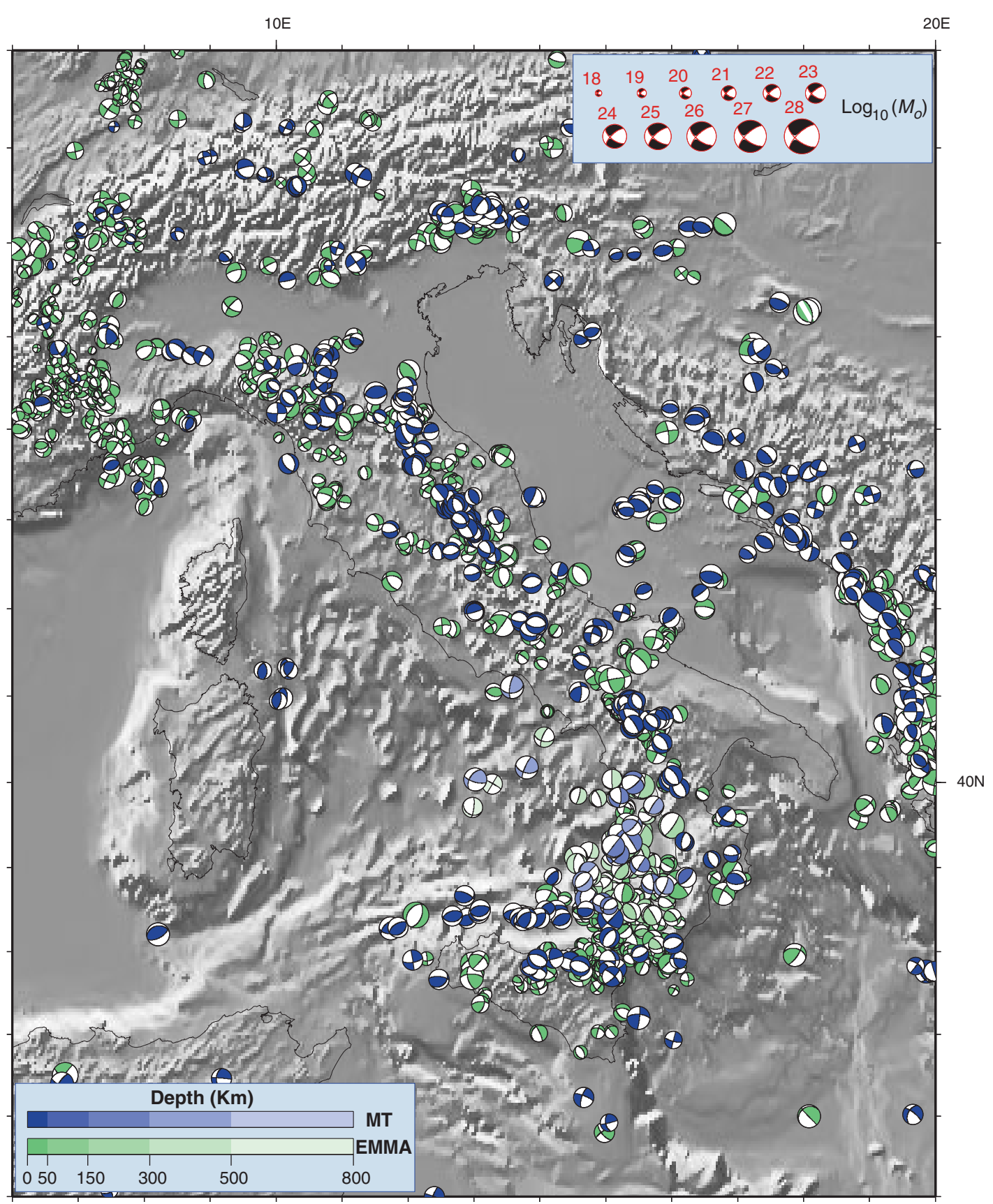

Fig. 10. Central Mediterranean. Focal mechanisms of earthquakes from MT catalogs (blue) and EMMA database (green). 
es that agree with Africa-Europe convergence (fig. 10; DeMets et al., 1994; Sella et al., 2002; McClusky et al., 2003). This kind of foreland seismicity might avoid the rift zone because there heat flow is still high (Argnani and Torelli, 2001).

The Maghrebian fold-and-thrust belt of Sicily can be considered as the eastward continuation of the Tell and is composed by a stack of Meso-Cenozoic sediments deposited along the African passive margin and its adjacent basin (Roure et al., 1990; Catalano et al., 1995). This tectonic stack formed mostly during the coeval opening of the Balearic and Tyrrhenian backarc basins, in a subductive environment, and has been subsequently emplaced onto the continental foreland of Sicily since the Pliocene (Hill and Hayward, 1988; Argnani, 2000a). Palaeomagnetic data from Sicily indicate that large clock-wise rotation, mostly occurring between Langhian and Late Tortonian, affected the Mesozoic to Pliocene sediments stacked within the fold-and-thrust belt (Channell et al.,1990; Speranza et al., 1999). The front of the Maghrebian fold-and-thrust belt, located in the southern offshore, appears sealed by Late Pleistocene sediments (Argnani, 1987), although some younger out-ofsequence thrusting has been reported on land (Lickorish et al., 1999). The seismicity of Sicily includes some large magnitude earthquakes, such as the historical 1693 Eastern Sicily event, $I_{\max }=$ XI (Valensise and Pantosti, 2001a). Deep seismicity is present in the Southeastern Tyrrhenian Sea, along an approximately continuous, NE-SW striking and NW dipping Benioff plane. The seismic slab is narrow (200 km) and steep $\left(70^{\circ}\right)$, and can be followed down to about $600 \mathrm{~km}$ (fig. 11; Wortel and Spakman, 2000; Faccenna et al., 2003; Piromallo and Morelli, 2003), representing the best example of subducted seismic slab in the Mediterranean. Focal mechanisms of deep events show mostly a down dip geometry (fig. 11). This slab is physically connected to the oceanic lithosphere of the Ionian Sea (Mele, 1998), as confirmed by seismicity distribution (figs. 10 and 11) and tomographic images (Wortel and Spakman, 2000; Piromallo and Morelli, 2003). Subduction has been going on till recently, or is still active, although at a rate (5 $\mathrm{mm} / \mathrm{yr}$ ) that is much reduced when compared to some long-term geological estimates $(>30 \mathrm{~mm} / \mathrm{yr}$ ), which also include a large contribution from trench retreat (Malinverno and Ryan, 1986; Patacca et al., 1990; Faccenna et al., 2004). The NW-ward subduction of this oceanic lithosphere from Late Miocene to Pleistocene, is responsible for the opening of the Tyrrhenian Basin, in a backarc setting, with tectonic activity progressively younger towards SE. The Tyrrhenian Basin is located on the wake of the Apennines and Sicilian Maghrebides, with the current sea floor that is rather shallow in its northern part (less than $1000 \mathrm{~m}$ ) and becomes deeper (over $3000 \mathrm{~m}$ ) to the south. The amount of extension is greater in the southern basin which, in fact, is characterised by thin crust (less than $10 \mathrm{~km}$ ) and high heat flow (Kastens et al., 1988; Marani and Trua, 2002). Large volcanic seamounts, 20-45 km long and elongated roughly north-south, are located in the Southern Tyrrhenian Basin. A girdle of volcanic islands, the Aeolian Islands, located north of Sicily represents the volcanic arc of the Tyrrhenian subduction, with calc-alkaline activity that spans from 1 Ma to the Present (Barberi et al., 1974; De Astis et al., 2003).

It is worth noting that deep events occurring beneath the Tyrrhenian Basin are located only east of the Aeolian Islands (figs. 3 and 4). Further to the west, along the Northern Sicily coast, seismicity is shallow and concentrated along an E-W alignment. Thrust fault mechanisms for shallow earthquakes located offshore (fig. 10) are highly consistent and their compressional $P$-axes are oriented in a NNW-SSE direction, according to the compressional regime found troughout Northern Africa and also in agreement with predicted Africa-Europe plates convergence (DeMets et al., 1994; Sella et al., 2002; Hollenstein et al., 2003; McClusky et al., 2003; Pondrelli et al., 2004b). At the same time, extensional to strike-slip focal mechanisms prevail along a nearly NNW-SSE alignment, connecting the Aeolian Islands to Mt. Etna, and east of Aeolian Islands only few extensional focal mechanisms are present (fig. 10). These characteristics of seismicity seem to indicate that the Aeolian Islands zone marks an abrupt change in the deformation regime (figs. 6 and 7). Although the tectonic structures that should control the NNW-SSE alignment appear rather elusive, some hints suggest that the subducted portion of the Malta Escarpment might have played a role (Argnani, 2000b; Doglioni et al., 2001; Argnani et al., 2002a). 

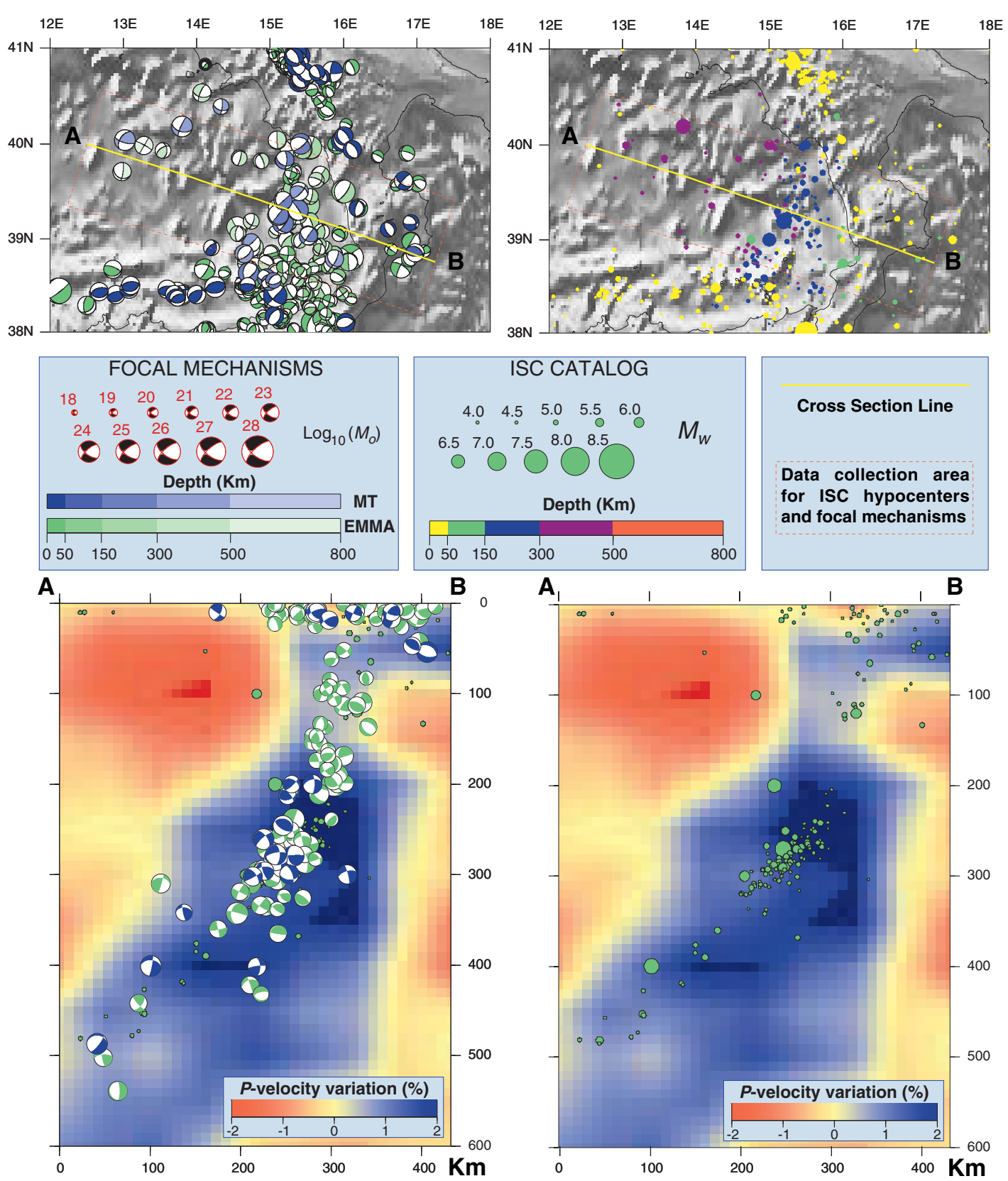

Fig. 11. Cross section of the Calabrian Arc: depth distribution of instrumental seismicity (from ISC Catalog) and focal mechanisms from EMMA database (green) and MT catalogs (blue). 


\section{The Central Mediterranean: Peri-Adriatic Province}

The current seismicity and seismotectonics of the Central Mediterranean region, as well as its longterm geological evolution, are largely influenced by the presence of the Adriatic Continental Block. Geological palaeo-reconstructions have taken Adria both as an independent block or as an African promontory (Channell et al., 1979; Dercourt et al., 1986). Palaeomagnetic data, however, indicate a common path for the Mesozoic palaeopoles of Africa and Adria (Channell, 1986; Muttoni et al., 2001). It should be mentioned, however, that recent GPS results point to some degree of independence of Adria with respect to Africa, lacking, nevertheless, to identify the location of possible discontinuities (e.g., Battaglia et al., 2004).

\subsection{Calabrian Arc and the Apennines}

The front of the Maghrebian fault-and-thrust belt joins to the east with the external Calabrian Arc, which represents the connection between Sicily and Southern Apennines (Rossi and Sartori, 1981). The Calabrian Arc is characterised by a stack of basement units (similar to those cropping out in the internal Tell), coming from different levels of a Hercynian continental crust (Amodio-Morelli et al., 1976; Bonardi et al., 2001). A thick forearc sedimentary succession crops out in the Ionian side of Calabria, supporting the accretion of the Calabrian Arc terranes within a subduction system (Bonardi et al., 2001). The External Calabrian Arc is a wide accretionary complex that extends into the Ionian Sea to touch the Mediterranean Ridge, SW of Keffalinia, and that is confined to the NE and SW by the Apulian and Malta Escarpments, respectively (figs. 1 and 2).

The onshore Calabrian Arc has been affected by major uplift in the last $0.8 \mathrm{Ma}$, with rates close to $2.0 \mathrm{~mm} / \mathrm{yr}$ (Westaway, 1993; Bordoni and Valensise, 1998), and presents extensional grabens trending NE-SW and NW-SE, filled by Late Pliocene-Quaternary sediments (Tortorici et al., 1995). Current seismicity in Calabria is clearly different from that observed in Sicily, being more sparse and characterised by largest events with small to moderate magnitude (figs. 3 and 10). This area is however also affected by large earthquakes, such as the $M=7.01908$ Messina Strait event (De Natale and Pingue, 1991; Valensise and Pantosti, 1992; Amoruso et al., 2002). Focal mechanisms show extensional geometry that confirms the presence of active extensional deformation, in agreement with background seismicity (Frepoli and Amato, 2000), GPS measurements (Serpelloni et al., 2002) and field geology (Cucci et al., 1996; Cinti et al., 1997, 2001).

It is however evident that the dominance of compression driven by the Africa-Europe convergence, previously seen along North Africa and Sicily, no longer holds in Calabria. This discrepancy with major plate motion can be observed throughout the Apennines. It is only in the Eastern Alps that earthquake focal mechanisms start tracking major plate motion again.

The Southern Apennines consist of a pile of thrust sheets composed of basinal sediments encasing a thick carbonate platform unit, the Apennine Platform (Mostardini and Merlini, 1986; Casero et al., 1988; Argnani, 2000a; Menardi Noguera and Rea, 2000). This tectonic stack, corresponding to an accretionary prism, was thrusted onto the Apulian carbonate platform, that represents the Adriatic continental foreland, in Early Pliocene (Argnani, 2000a; Menardi Noguera and Rea, 2000). The subsequent deformation also affected the Apulian platform and its continental basement, although the degree of basement involvement is controversial. Palaeomagnetic data from the structural units of the Southern Apennines indicate that a substantial post-Langhian counter-clock wise rotation occurred during their emplacement (Gattacceca and Speranza, 2002). Thrusting within the Southern Apennines possibly stopped in the Early Pleistocene (Patacca et al., 1997). NW-SE-trending extensional faulting affected the inner part of the Southern Apennines (Hippolyte et al., 1995) during Tyrrhenian opening (Late Miocene-Early Pleistocene), whereas superficial ruptures due to recent and historical earthquakes are mainly concentrated about the mountain watershed (Valensise and Pantosti, 2001b). 

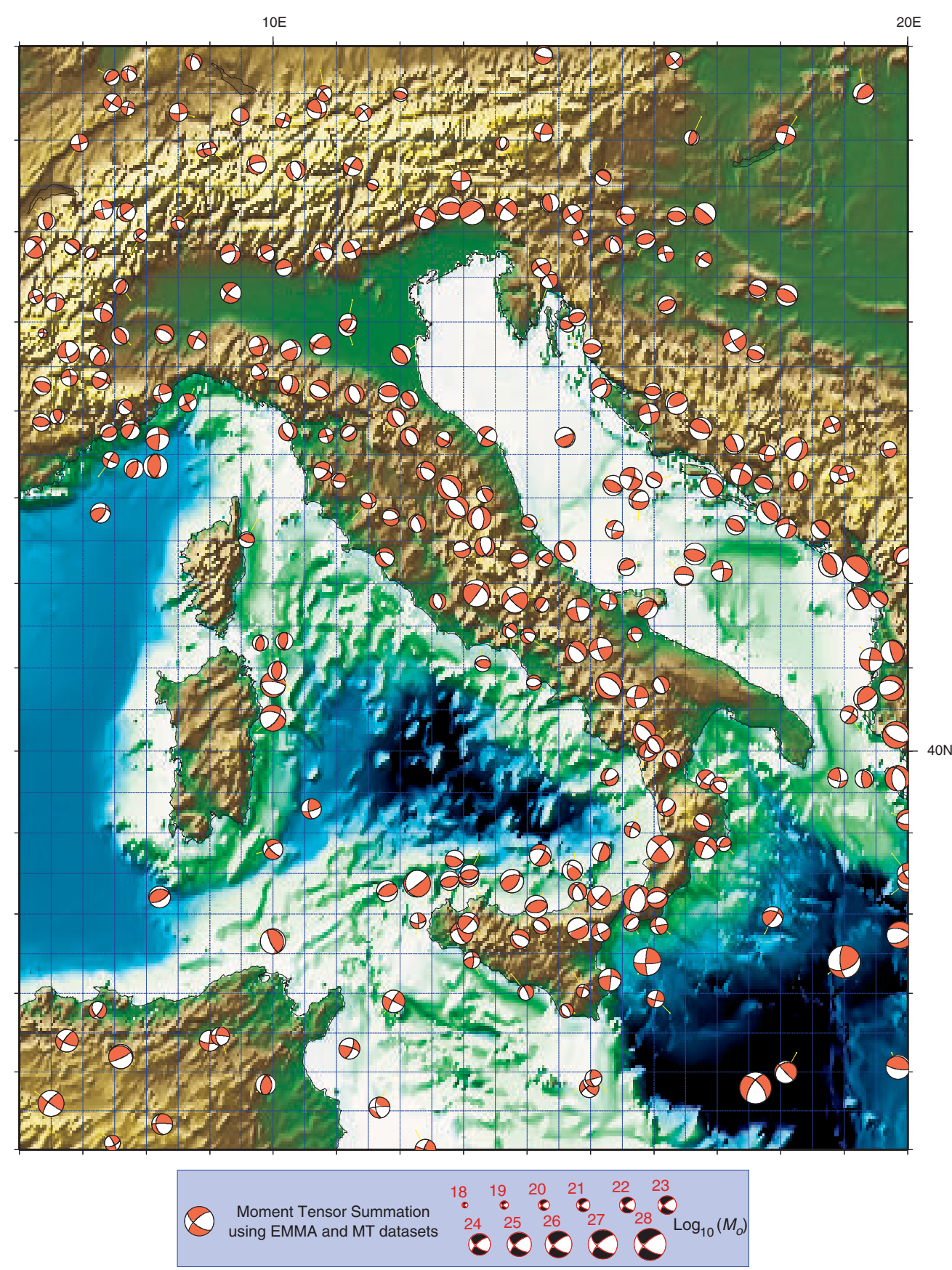

Fig. 12. Central Mediterranean. Sum of moment tensors on a regular grid with mesh of half a degree, for earthquakes with depth $<50 \mathrm{~km}$. The focal mechanism plots are scaled with magnitude and located in the barycenter of the epicenters distributions weighted with magnitude. 
$10 \mathrm{E}$

$20 \mathrm{E}$

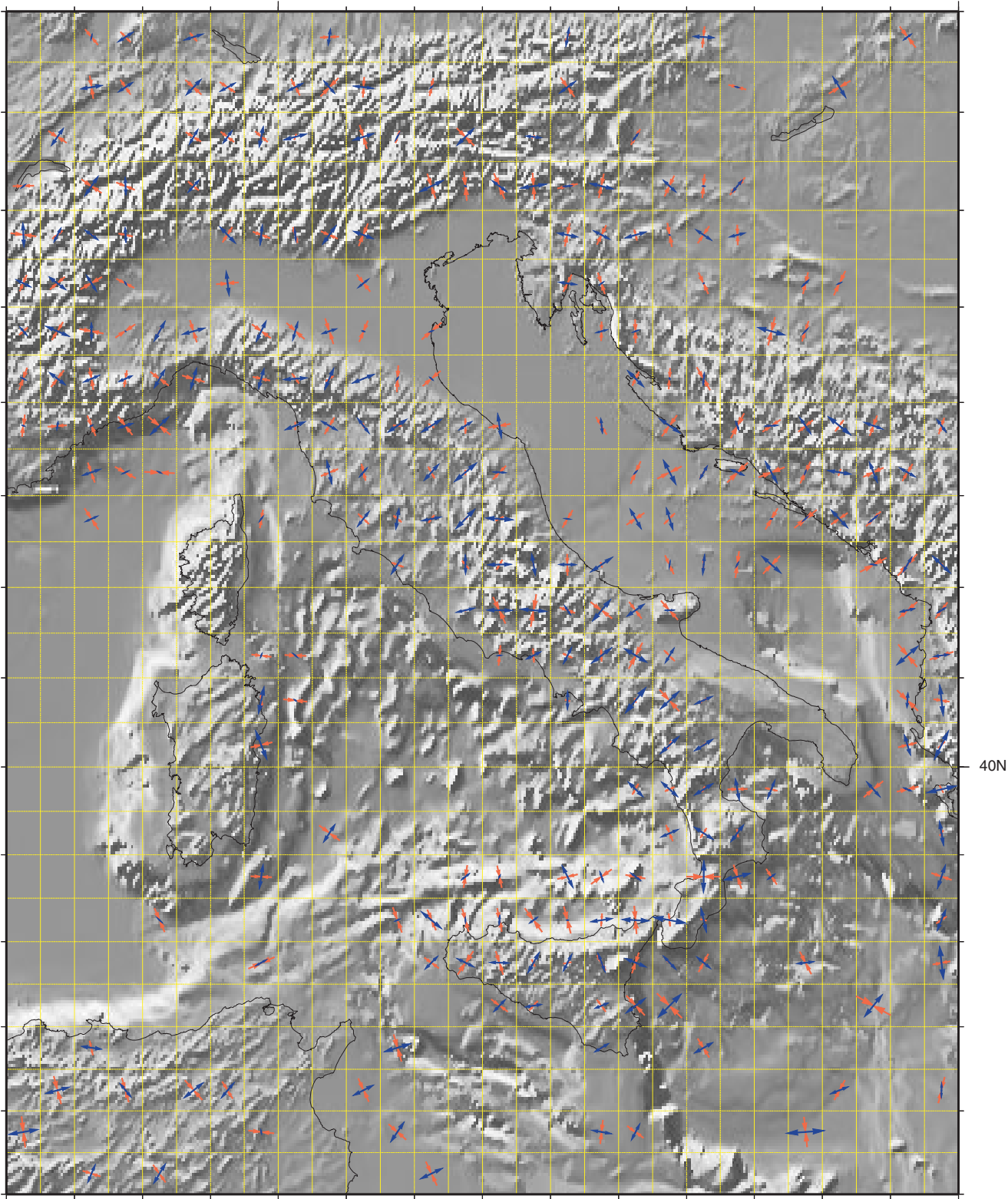

Plot of $P$ - and T-AXES on horizontal plane

P-AXIS (MAX compressional deformation) T-AXIS (MIN compressional deformation)

Fig. 13. Central Mediterranean. Horizontal projections of $P$ and $T$ deformation axes, on a regular grid with mesh of half a degree, derived from the sum of moment tensors (Kostrov, 1974) of earthquakes with depth $<50 \mathrm{~km}$. 
Present-day seismicity of the Southern Apennines is relatively intense and frequent. Earthquakes, including the largest magnitude events, are mainly located in a narrow belt corresponding to the highest relief of the chain (fig. 3), and typically occur at a hypocentral depth comprised within the first 10-12 km. Focal mechanisms uniformly show extensional geometry throughout the chain, in continuity with the Calabrian Arc extension (fig. 10). Some additional earthquakes, mainly showing a strike-slip component, are located in the outer part of the Apennines and in the Gargano promontory, in a foreland position. It is worth noting that both the recent 2002 Molise seismic sequence (Pondrelli et al., 2003) and two seismic sequences which occurred in 1990 and 1991 around Potenza show strike-slip events that have a hypocentral depth comprised between 15 and $25 \mathrm{~km}$, i.e. deeper than the typical Southern Apennine earthquakes. The depth of these earthquakes is also larger than the estimated depth of the Apennine edifice (e.g., Mostardini and Merlini, 1986), locating these events in the subducted Adriatic crust.

This different geometry of deformation is also evident from the map representing the seismic deformation of this region, obtained by a moment tensor summation on a 0.5 degree per 0.5 degree grid (figs. 12 and 13). The narrow and continuous belt of extensional deformation runs from the Messina Strait to the Irpinia region and is also outlined by the extensional $T$-axes which are always perpendicular to the chain and by moment tensor summation (fig. 5). The pattern of seismic deformation is less clear and more heterogeneous at the Gargano latitude and northward, being mainly characterized by compressional deformation in the outer part of the chain and in the foredeep (figs. 10 and 12). Fault planes of some of the major extensional events, such as part of the source of the $1980 M_{s}=6.8$ Irpinia earthquake, dip to the NE (Westaway and Jackson, 1987; Bernard and Zollo, 1989; Amato and Selvaggi, 1993; Pantosti et al., 1993; Improta et al., 2003). This kind of tectonics would therefore be at variance with respect to the backarc extensional tectonics, that is characterised by a system of west dipping fault planes as those located near the Tyrrheanian coast (Argnani, 2000b).

The transition between the Southern and the Central Apennines is characterized by compressional and strike-slip focal mechanisms (fig. 10). However, extension perpendicular to the mountain belt continues all the way to the Northern Apennines, as indicated by individual focal mechanisms (fig. 10) and by $P$ axes of moment tensor sums (figs. 12 and 13).

The Northern Apennines are composed of a tectonic stack of mainly east-vergent thrust units (Kligfield, 1979; Hill and Hayward, 1988). The Ligurian terranes and their sedimentary cover represent the uppermost unit and overlay the deformed units, mainly sedimentary, of the Adriatic continental margin of the Tethyan ocean (Abbate and Sagri, 1970). The Northern Apennines originated during the late Cretaceous to Present convergence between the European and African plates (Carmignani and Kligfield, 1990; Doglioni et al., 1998; Argnani, 2002). The initial stage of oceanic subduction led to the formation of the Ligurian accretionary wedge, the uppermost nappe system of the Apennine stack, which were emplaced tectonically over the basinal sediments of the Tuscan units, deposited on the Adriatic continental margin. Subsequently, the local convergence between Adria and the continental Corsica-Sardinia Block, counterclockwise rotating ahead of the opening Balearic backarc basin (Todesco and Vigliotti, 1993; Vigliotti and Langenheim, 1995; Muttoni et al., 1998, 2000), led to a progressive deformation of the units of the Adriatic continental margin. The basement of the Tuscan succession has been affected by deformation and crops out in a few tectonic windows in the internal part of the Apennines (e.g., Apuane Alps and Monti Pisani; Kligfield, 1979). Following the convergence of Corsica-Sardinia, the eastward migration of a system of foredeep basins occurred, with the last foredeep basin currently located in the Po Plain and the Adriatic Sea (Ricci Lucchi, 1986; Argnani and Ricci Lucchi, 2001). A system of arcuated thrust faults is located in the subsurface of the Po Plain (Pieri and Groppi, 1981) and represents the most external front of the Apennines. The Tyrrhenian side of the Northern Apennines was affected by a regional extensional regime in the Late Messinian-Early Pliocene (Bartolini et al., 1982; Martini and Sagri, 1993) and seismic profiles indicate that extensional activity decreased following the Early Pliocene (Argnani et al., 1997). On the other hand, small grabens filled by Quaternary sediments characterize the watershed of the Northern Apennines (Bartolini et al., 1982; Martini and Sagri 1993; Argnani et al., 1997). 
Although some subcrustal seismicity, down to $90 \mathrm{~km}$ depth, has been recorded beneath the Northern Apennines (fig. 4; Selvaggi and Amato, 1992), most of the seismic activity in the mountain range is occurring within 10-12 km depth, and is characterized by extensional focal mechanisms. On the other hand, in the Po Plain and in the outer part of the Apennines, seismic events are often deeper $(15-20 \mathrm{~km})$ and show compressional to strike-slip focal mechanisms, with direction of $P$-axes ranging from N-S to NESW (figs. 12 and 13; Frepoli and Amato, 1997; Mariucci et al., 1999; Montone et al., 1999, 2004). Despite minor complexities, the major trend of seismic deformation along the Apennines is dominated by extension (fig. 5).

\subsection{Alps and Dinarides}

The Alps have represented the classic example of mountain belt since the dawn of geology (Dal Piaz, 2001; Truempy, 2001). They originated by the convergence, and subsequent collision, between the European and African plates (Coward and Dietrich, 1989). It should be noted, however, that the proper collision occurred between Europe and Adria, the continental promontory of Africa. In the early stages of convergence, from Late Cretaceous to Early Eocene, a Mesozoic oceanic domain (Alpine Tethys), presumably of only limited width, was subducted underneath Africa. Fragments and slivers of continental basement that drifted away from their parent continental domain were also involved in subduction (Dal Piaz, 1999). Continental collision progressed from Middle Eocene onwards to originate the present mountain range (Roure et al., 1996). To mechanically balance the increased shortening and uplift of the Alpine Belt, a crustal-scale retro-wedge thrust developed in the upper plate (Adria), originating the Southern Alps (Roeder, 1989). From Middle Eocene to Oligocene (but mainly during Oligocene) magmatic activity occurred in the Alps, particularly along the Periadriatic lineament. This magmatic activity is supposedly linked to slab breakoff (von Blankenburg and Davies, 1995; Macera et al., 2003; Piromallo and Faccenna, 2004).

The Eastern Alps represent the complex kinematic link between the Alps and the Alpine Belt of Eastern Europe, namely the Carpathians and the Dinarides, with the Pannonian Basin that adds further complexity (Haas et al., 2000). Besides north-south shortening, strike-slip and extensional faults characterised the Eastern Alps in late Oligocene-Miocene, causing an E-ward lateral extrusion (tectonic escape) towards the Pannonian region (Ratschbacher et al., 1991).

Seismicity is of low magnitude and quite scarce throughout the Alps (fig. 3), and the small number of focal mechanisms does not allow us to work out any particular trend, as testified by the seismic deformation map (figs. 10 and 12). Only in the Eastern Alps is the present-day seismic activity frequent and also characterised by large magnitude events, such as those belonging to the 1976 Friuli seismic sequence (fig. 10). Earthquake focal mechanisms are compressional with $P$-axes trending NNW-SSE (figs. 12 and 13), in agreement with the Africa-Eurasia convergence direction in this region (DeMets et al., 1994; Sella et al., 2002; McClusky et al., 2003). The same also apply to the major summary moment tensor, that shows a dominant thrust solution with a minor strike-slip component (fig. 5).

Moving southeastward to enter the Dinarides region, seismicity shows a similar pattern, but with lower magnitude events and usually with increasing strike-slip components within focal mechanisms (fig. 10). Compressional $P$-axes of seismic deformation maintain the agreement with the expected Africa-Eurasia direction (figs. 5, 10 and 13). On the other hand, the Dinarides Chain is part of a continuous west-vergent fold-and-thrust belt that runs from the Eastern Alps to the Hellenic Arc and that originated by the subduction of the Adriatic (Africa) Domain underneath Europe (Auboin et al., 1970; Moretti and Royden, 1988; Lawrence et al., 1995). Basinal sediments, including Jurassic ophiolite slivers, occur in the inner part of the belt. Subduction occurred from Late Jurassic-Early Cretaceous until late Eocene, consuming an oceanic basin that opened from Late Triassic to Late Jurassic (Pamič et al., 2002). Ophiolites were emplaced on the Adriat- 
ic Domain, once the oceanic basin closed, and thrusting subsequently affected the Adriatic-Dinaric carbonate platform (Pamič et al., 2002). Thrusting terminated mainly in Late Eocene-Early Oligocene, although it continued in the Dubrovnik area until late Oligocene and until Present, near the Albanian border, where neotectonic deformation occurs (Argnani et al., 1996). Strikeslip tectonics seems to have dominated from late Oligocene to the present in the internal part of the belt, where the NW-SE-trending Drava-Sava system (DSS, right-lateral strike-slip) marks the boundary with the Pannonian Basin (Tari and Pamič, 1998). Seismicity along the eastern coast of the Adriatic Sea is important south of Croazia, where seismic activity is frequent, also with large magnitude events (e.g., the $M=6.8,1979$ Montenegro earthquake) and well localized along the

$20 \mathrm{E}$

$30 \mathrm{E}$

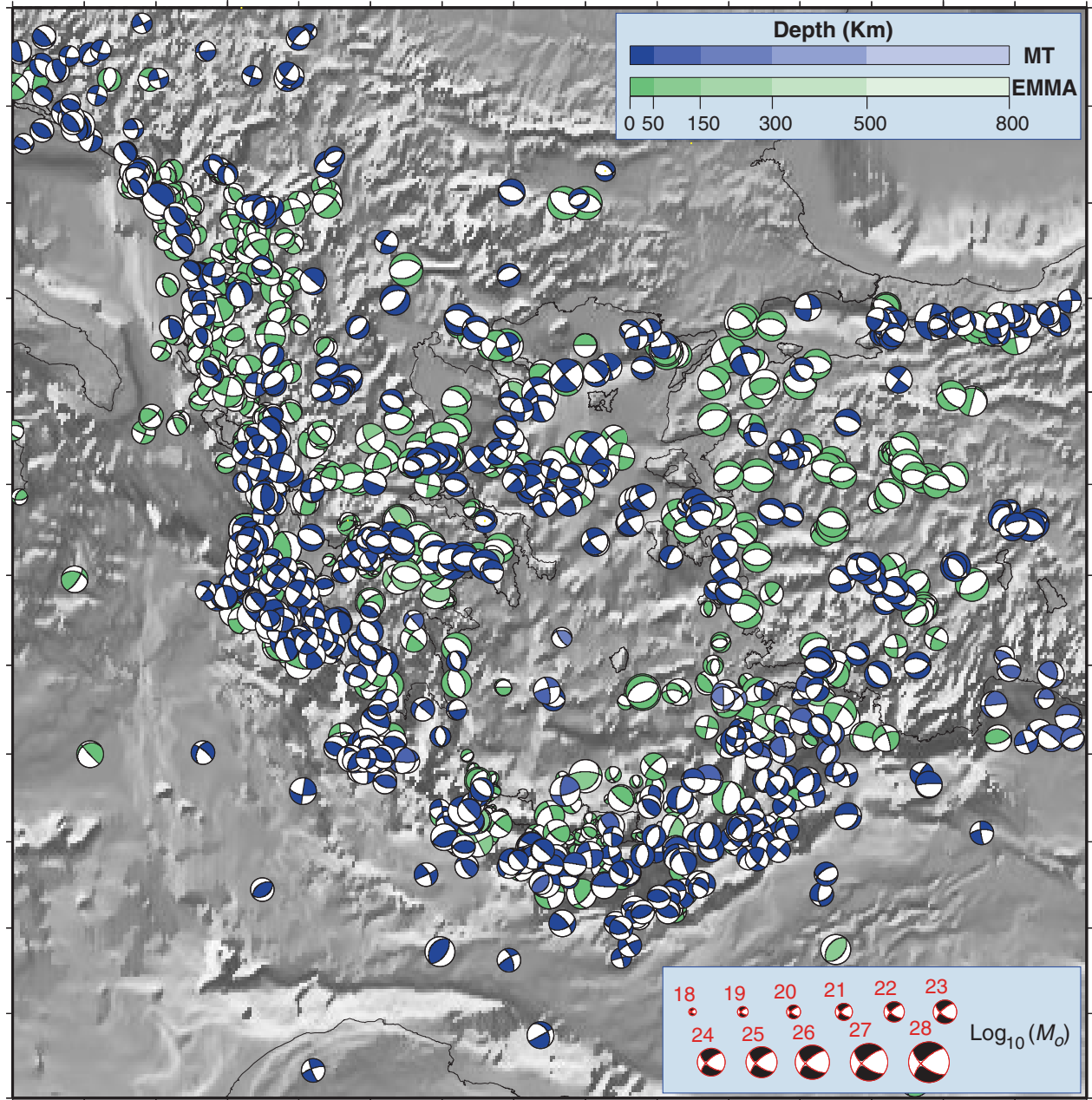

$40 \mathrm{~N}$

Fig. 14. Aegean province. Focal mechanisms of earthquakes from MT catalogs (blue) and EMMA database (green). 
outer front of the Dinarides (figs. 10 and 14). Focal mechanisms are uniformly thrust, with only few isolated strike-slip mechanisms. Strike-slip and thrust earthquakes' focal mechanisms occur equally in the interior of the Dinarides, where seismicity, however, is less abundant (figs. 10 and 14). The seismic deformation map illustrates the compression occurring along the narrow zone located in the outer part of the chain, with $P$ compressional axes NE-SW trending (fig. 5) and the same trend can be followed continuously in the regular mesh moment tensor summation (figs. 12, 13,17 and 18).

Some seismicity is also detected within the Adriatic Sea, with most of these earthquakes showing thrust focal mechanisms (fig. 10) and defining a diffuse compressional zone connecting the Apennine foreland with the Dinarides. Seismic surveys in the Adriatic Sea have shown the occurrence of tectonic structures, mainly open folds and reverse faults, that do not appear related to the outer Apennines (Argnani et al., 1993, 2002b; De Alteriis, 1995; Argnani and Frugoni, 1997). This deformation is limited and presents some variety in structural directions, supporting reactivation of pre-existing faults in a regime of tectonic inversion. In fact, Early Mesozoic extensional faults have been documented by oil industry research in the Central Adriatic (Gambini et al., 1997). It has been suggested that stresses from the adjacent Dinarides and Apennines caused intraplate deformation (Argnani et al., 1993). However, it is also possible that the stresses due to the push of Adria, that is indenting Europe, are felt as far south as the Central Adriatic.

To sum up, it seems that Adria is relatively aseismic but is surrounded by seismogenic zones on its western, northern and eastern sides. Whereas thrust faulting characterizes the northern and eastern side of Adria, the western side is dominated by extensional faulting in the Apennines.

\section{The AEgEAn PROVINCE AND ADJACENT REgIONS}

This region is the most tectonically and seismically active within the Mediterranean and marks the transition between the Mediterranean backarc basins to the west and the region with high plateaus to the east (fig. 2). The distribution of tectonic structures and earthquake focal mechanisms suggests that this region can be subdivided into two major domains, a convergent boundary, running along the Albanides, Hellenides and Hellenic Arc, and an extensional domain, covering the Aegean and Western Anatolia areas (fig. 3).

\subsection{Albanides, Hellenides and Hellenic Arc}

The convergent boundary can be followed from Albania to the eastern end of the Hellenic Arc (Burchfiel, 1980; Horvath, 1988; Chaumillon and Mascle, 1995). The Albanides continue towards the south from the Dinarides, with a close correspondence of isopic facies belts and sedimentary facies (Aubouin and Ndojaj, 1964). Similarities with the Hellenides, further to the south, are even more remarkable (Bornovas and Rondogianni-Tsiambaou, 1983) and, in fact, the two fold-andthrust belts can be described together (Celet, 1977). It is also worth noting that the Albanides share with the Hellenides a conspicuous Miocene-Pliocene clockwise rotation of the external units, accompanying the opening of the Aegean Sea (Mauritsch et al., 1995; Speranza et al., 1995; Duermeijer et al., 2000). In the internal part of the Albanide-Hellenide Belt, Jurassic ophiolites were emplaced between Late Jurassic and Early Cretaceous. The Korab-Pelagonian microcontinent was involved during ophiolite emplacement and oceanic closure, although its role is still debated. In fact, several, often contrasting, scenarios have been proposed to account for the pre-Eocene evolution of the Albanides-Hellenides (Robertson et al., 1996). From Eocene onward, however, all Authors agree that the continental units of Apulia (i.e. part of Adria) were progressively accreted to the fold-and-thrust belt (Celet, 1977). Shortening continued until the present involving units of the 
Adria margin (carbonate platform and basin successions), as supported by present-day seismicity at the Albanide-Hellenide thrust front. As for the Southern Dinarides, earthquakes with compressional focal mechanisms and moderate magnitude are located in the outer thrust fronts (figs. 3 and 12). In the internal part of the fold-and-thrust belt, seismicity is more frequent and characterised by typically extensional earthquakes, often with large magnitude, e.g., the $M_{s}=6.6,1995$ KozaniGravena event (Hatzfeld et al., 1997). Earthquake focal mechanisms and the related seismic deformation show an active extensional regime that propagates all over Albania and Southern Greece, reflecting the dominant tectonic regime of the Aegean backarc (fig. 14).

Although the Hellenides represent a continuous belt from Albania to the Peloponnesus, it is worth noting that the frontal part is characterised by continental collision north of Keffalinia, whereas to the south of the island, oceanic subduction occurs (Underhill, 1989). It is perhaps for this reason that the NESW striking Keffalinia Fault represents one of the most seismically active structures of the Mediterranean. Strike-slip focal mechanisms dominate along it, often with low angle fault planes, interrupting the compressive front, represented by the numerous focal mechanisms located north and south of the Keffalinia Fault itself, but underlining that the southern part of the belt is displaced SW-ward respect to the northern one (figs. 2 and 14).

The change in tectonic setting from collision to subduction appears evident in the distribution of seismicity. In fact, although events with moderate magnitude prevail throughout the belt, their depth increases on average moving southward (figs. 4). In particular, hypocenters of shallow, intermediate and deep events outlining a NE-dipping plane occur south of Keffalinia. Deep seismicity occurs within $200 \mathrm{~km}$ depth along a gently dipping plane (about $30^{\circ}$ ) toward NE in the western branch of the Hellenic trench and toward NNW in the eastern branch (figs. 15 and 16). The Eastern Mediterranean subduction extends for about $2000 \mathrm{~km}$ from Keffalinia to Rhodes (de Jonge et al., 1994; Mascle and Chaumillon, 1997; Wortel and Spakman, 2000; Faccenna et al., 2003; Piromallo and Morelli, 2003) and continues to the east, with a separate arc located south of Cyprus (Vidal et al., 2000). This subducting system is characterised by oceanic subduction throughout, passing to the west to the continental collision of the Northern Hellenides, and to the east to the Bitlis suture and East Anatolia Transform Fault. The accretionary complex is represented by the Mediterranean Ridge, which is up to $300 \mathrm{~km}$ wide and covers most of the Eastern Mediterranean Basin, almost touching the coast of Africa near the Cyrenaica Peninsula (Chaumillon and Mascle, 1995). A system of deep troughs, the Hellenic Trench, parallels the front of the Mediterranean Ridge in its internal part. This morphologic forearc basin represents the front of the former, early Miocene, accretionary wedge, giving an impressive figure of up to $15 \mathrm{~km} / \mathrm{Myr}$ (for the western side) for the outward growth rate since that time (Kastens, 1991; Kopf et al., 2003). Morphobathymetric surveys have revealed that mud volcanoes, often in large fields, and brine pools at the sea floor are widespread throughout the Mediterranean Ridge, supporting the major role played by fluids and Messinian salt into the accretionary wedge mechanics (Kopf et al., 2003).

Seismicity reflecting the subductive boundary can be followed from Keffalinia to the eastern end of the Hellenic Arc (figs. 15 and 16). It is worth noting, however, that beside the deep events related to subduction, seismicity is only sparse towards the front of the Mediterranean accretionary wedge, possibly because of the abundance of fluids. In fact, most of events occur along some portions of the Hellenic Trench, for instance in correspondence of the Peloponnesus and Crete, in a forearc position (fig. 3). This trench seismicity shows, in the western branch, a dominance of compressional events, with subordinate strike-slip solutions, all showing compressional $P$-axes trending N-NE on average. Seismic deformation also confirms this trend (figs. 5, 17 and 18). On the other side, along the eastern branch, the pattern is slightly more complex and focal mechanisms are more heterogeneous, with strike-slip solutions becoming more abundant and with more variety in the direction of fault planes (fig. 14). The $P$-axis, however, still trends N-NE on average in the moment tensor summation on the whole region (fig. 5), but on the regular 0.5 mesh grid, they show the lack of a unique trend (figs. 17 and 18). Indeed, besides the differences in the seismicity characteristics of the two branches of the Hellenic trench, the whole moment ten- 

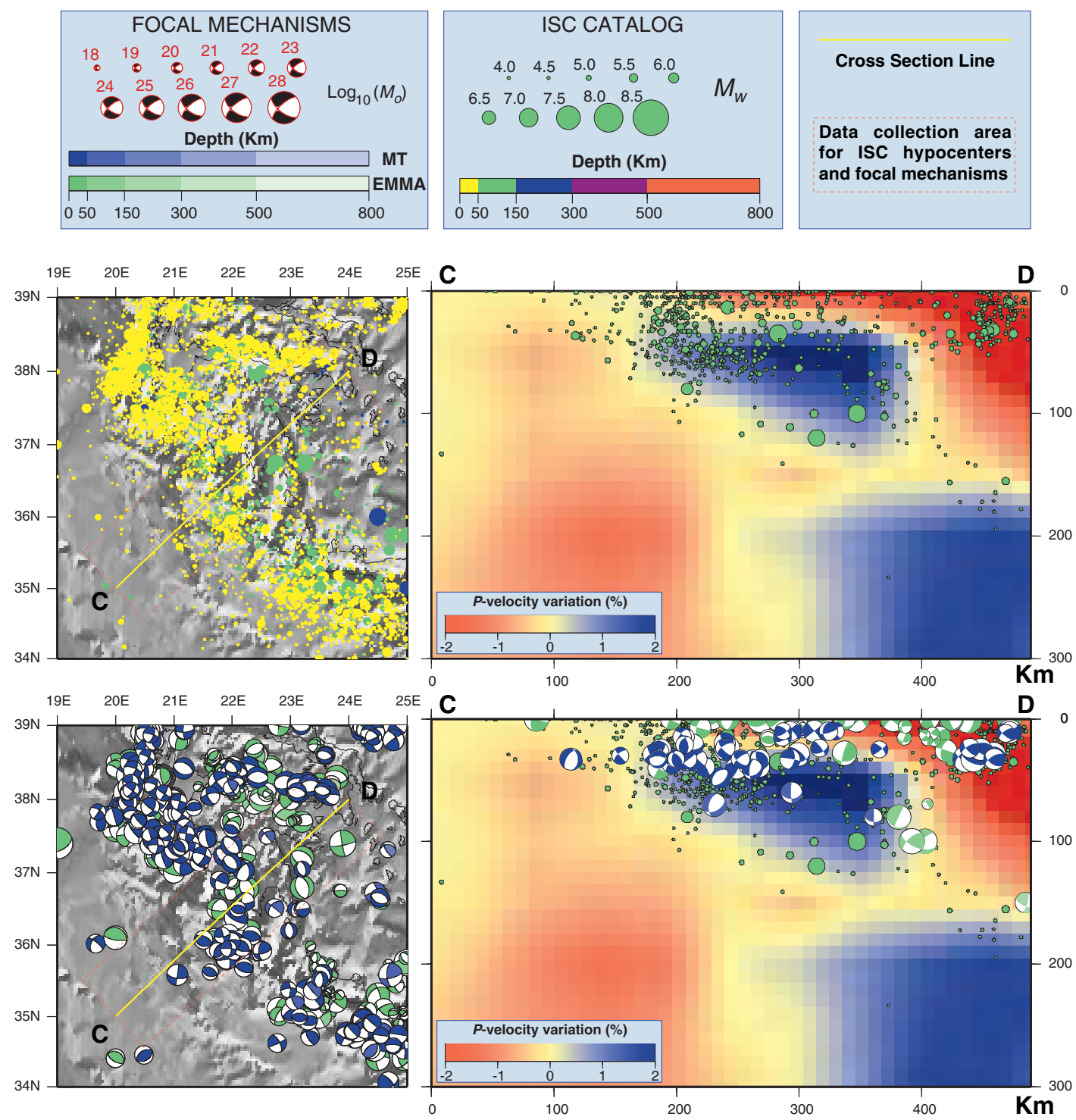

Fig. 15. Cross section of the Western Aegean Arc: depth distribution of instrumental seismicity (from ISC catalog) and focal mechanisms from EMMA database (green) and MT catalogs (blue).

sor summation performed on data of shallow events shows a dominantly thrust solution, equally NE trending, for both seismogenic zones (fig. 5).

It might be interesting to note that the summary focal mechanisms with hypocentral depth greater than $50 \mathrm{~km}$ (figure in the enclosed CD-ROM) show a strike-slip solution for both the western and east- 

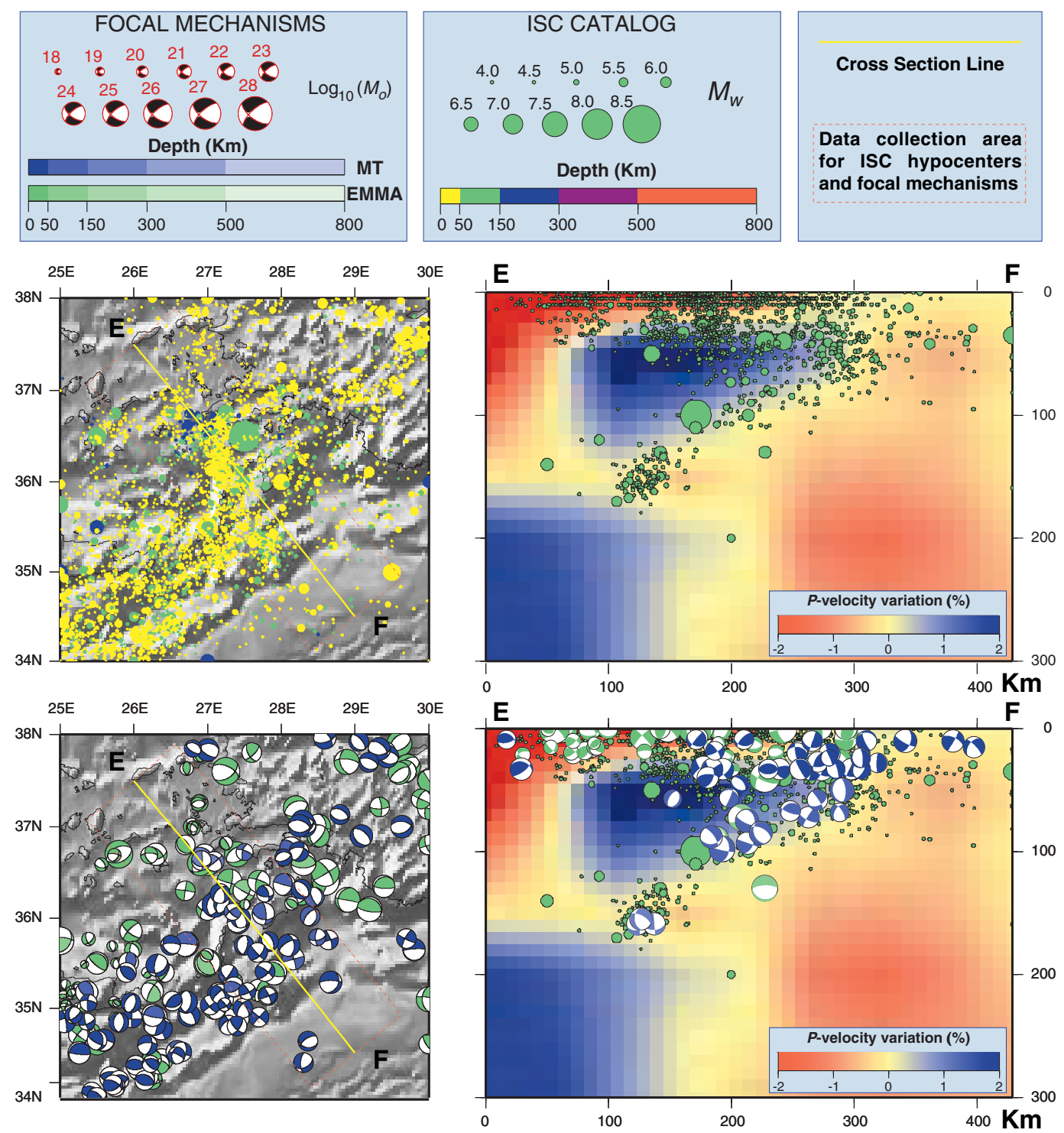

Fig. 16. Cross section of the Eastern Aegean Arc: depth distribution of instrumental seismicity (from ISC Catalog) and focal mechanisms from EMMA database (green) and MT catalogs (blue).

ern branches of the Hellenic Arc. This pattern resembles the occurrence of some flexural folding along the arc, assuming that fault planes are those trending ca. E-W (Benetatos et al., 2004). Finally, it is worth noting that, along the Western Hellenic trench, GPS measurements revealed the largest velocity of the entire Mediterranean (Khale et al., 2000). 


\subsection{Aegean Sea extensional domain}

Beyond the Hellenic trench, a different tectonic regime defines another domain, extending over most of the Aegean Sea, mainland Greece and Western Turkey. This broad area is undergoing, on average, NS extension (figs. 17 and 18; McKenzie, 1978; Dewey and Şengör, 1979; Dewey et al., 1986). The

$20 \mathrm{E}$

$30 \mathrm{E}$

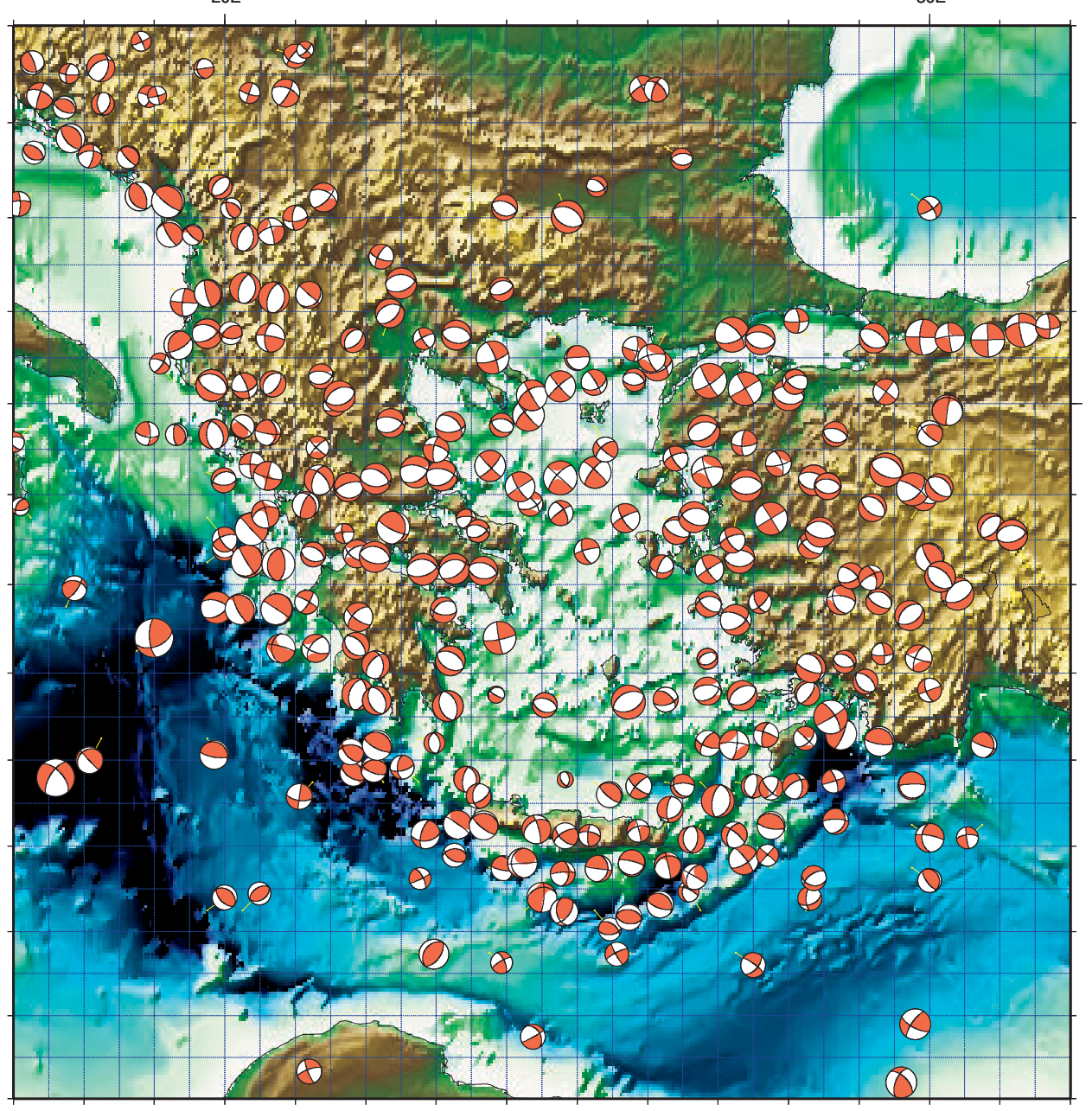

$40 \mathrm{~N}$

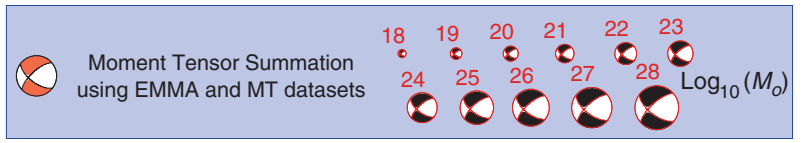

Fig. 17. Aegean province. Sum of moment tensors on a regular grid with mesh of half a degree, for earthquakes with depth $<50 \mathrm{~km}$. The focal mechanism plots are scaled with magnitude and located in the barycenter of the epicenters distributions weighted with magnitude. 


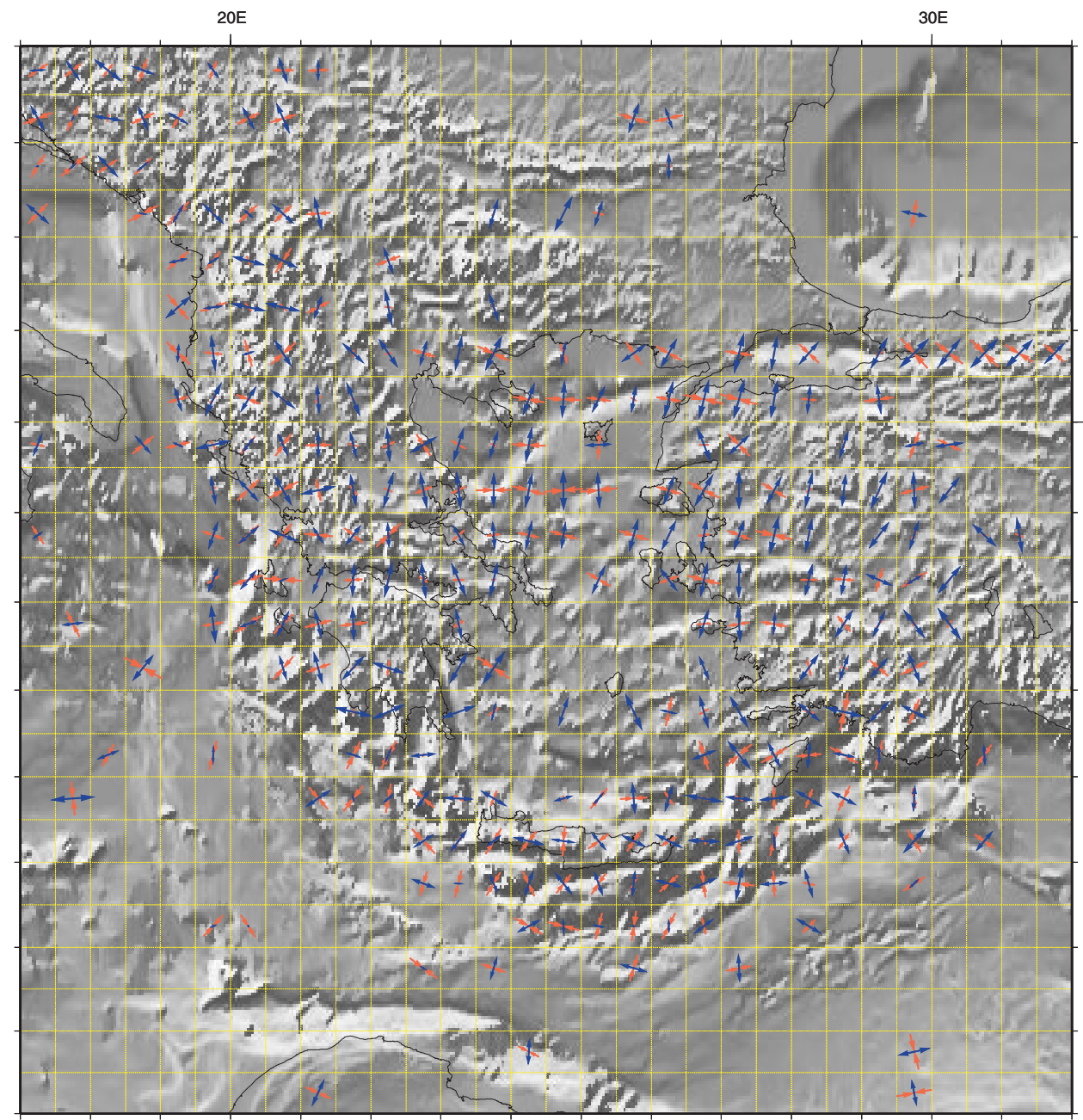

Plot of $P$ - and T-AXES on horizontal plane

P-AXIS (MAX compressional deformation) T-AXIS (MIN compressional deformation)

Fig. 18. Aegean province. Horizontal projections of $P$ and $T$ deformation axes, on a regular grid with mesh of half a degree, derived from the sum of moment tensors (Kostrov, 1974) of earthquakes with depth $<50 \mathrm{~km}$.

Aegean Sea is in fact a backarc basin that originated in the wake of the retreating Hellenic subduction; in its northern part, however, the westward moving Anatolian Block also exerts a major control.

The Aegean Basin is floored by a continental crust $25-30 \mathrm{~km}$ thick, that further thins to $20-25 \mathrm{~km}$ under the sea of Crete. Crustal thickness in the adjacent regions, mainland Greece and Turkey, is 30 to 40 $\mathrm{km}$ (Makris and Stobbe, 1984). Extensional tectonics in the Aegean region has originated a number of well developed metamorphic core complexes (Lister et al., 1984). These complexes, mainly cropping out 
in the Cyclades, are characterised by high pressure rocks, ranging in age from Late Cretaceous to Early Miocene, that were brought to surface on the footwall of low-angle extensional faults (Gautier et al., 1993). How much of this exhumation is due to syn-orogenic extension, and how much to post-orogenic (backarc) extension is still a matter of debate (e.g., Gautier, 2000).

The onset of extension in the Aegean backarc basin is still controversial. Middle-Late Miocene to Present extension and crustal thinning were typically assumed in the early works (Le Pichon and Angelier, 1981); on the other hand, the Late Eocene extension, recorded also in Bulgaria (Burchfield et al., 2000), is sometimes taken as the beginning of Aegean backarc opening (Gautier, 2000; Trotet et al., 2001). However, it seems that the pre-Miocene extension in the Aegean region can be related to syn-orogenic exhumation, possibly in a forearc setting, rather than to true crustal thinning (Ring and Layer, 2003). In fact, widespread intrusions typical of backarc rifting, occurred in the Aegean Basin only from Middle Miocene onwards (Fytikas et al., 1984), a timing that corresponds to the sedimentary succession found in the whole Aegean Basin (Mascle and Martin, 1990) and in the E-W basins of West Turkey (Kurt et al., 1999; Bozkurt, 2001). Moreover, Late Eocene-Oligocene extension in Bulgaria occurred apparently within a magmatic arc (Burchfiel et al., 2000 ), whereas most of the recent extension in the North Aegean-South Balkan region seems related to the activity of the Northern Anatolia Fault, which here turns from E-W to NE-SW.

The western branch of the Northern Anatolian Fault has a ENE-WSW strike entering the North Aegean Sea and broaden into a $150 \mathrm{~km}$ wide zone, characterised by a complex basin system, composed by both NE-trending rhomb-shaped pull-apart basins (e.g., Sporades Basin) and NW-trending rift basins (e.g., Thermaikos and Orfanou basins), typically to the NW side of the Northern Anatolian Fault branch. The propagation of the Northern Anatolian Fault into the Northern Aegean Sea is outlined by the homogeneous strike-slip focal mechanisms of earthquakes (fig. 14). This transcurrent deformation occurs within a region dominated by an extensional regime (figs. 17 and 18). However, extensional $T$-axes of single focal mechanisms or summary moment tensors appear to be always about N-S, in agreement with a dominant extensional deformation in this direction (figs. 5 and 18). Neogene sediments within this complex basin system present separated depocenters, up to several km thick, suggesting a case of compartmentalized basins (Mascle and Martin, 1990; Koukouvelas and Aydin, 2002). Where the Northern Anatolian Transform Fault-related deformation zone enters into continental Greece, deformation is transformed into E-W to WNW-ESE-trending faults that rotate clockwise about a vertical axis, such as for instance the faults bounding the Corinth Gulf Basin. In this region, earthquakes with extensional focal mechanisms dominate, but fault plane directions present more scatter and $T$-axes also rotate away from N-S, particularly towards the convergent boundary (figs. 14 and 17). Both backarc extension and westward motion of Anatolia, whose western boundary is resolved as extensional faults rotating about vertical axes (Jackson, 1994), contribute to the complex pattern of seismicity observed in Greece. In addition, the presence beneath this region of the transition to a subductive boundary should be taken into account.

Seismicity in the Aegean region is highly frequent and occurs mostly in its southern part (fig. 3), while the low number of earthquakes in the central basin appears related to the fact that the lithosphere has been strain hardened during thinning (Sonders and England, 1989; Cianetti et al., 2001). The occurrence of a relatively stiff lithosphere in the Southern Aegean is also responsible for the transfer of pull, due to slab retreat, from the Hellenic trench to Western Anatolia (Cianetti et al., 2001). Earthquakes have maximum magnitudes that range from low to high. Focal mechanisms indicate that this broad area is undergoing, on average, a N-S extension as all surrounding regions, and this trend is also confirmed by the moment tensor summation calculated all over the Aegean Sea, that shows a present-day extensional deformation in a nearly N-S direction (figs. 14 and 17). Hence, on the eastern side of the Aegean Sea, Western Anatolia is characterised by a fast $\mathrm{N}-\mathrm{S}$ extension that again pertains to the Aegean extensional domain. As a result, E-W-trending grabens are the major tectonic features since Pliocene and along them extensional earthquakes are particularly frequent, with largest magnitude ranging from moderate to large, and with extensional $T$-axes consistently N-S (figs. 14, 17 and 18). According to some authors (Kocyigit et al., 1999), a previous episode, characterized again by N-S extension, but with extensional faults trending 
NNW to NE, occurred from Late Miocene to Early Pliocene. This region of fast N-S extension passes eastward to a region dominated by conjugate NW to NE strike-slip faults in the eastern part of Anatolia. A region characterized by NE-SW to NW-SE grabens marks the transition between these two tectonic domains.

\section{Anatolia And Cyprus}

Turkey presents one of the most complex types of geology within the Tethyan Domain: it resulted from a long history of subduction, starting perhaps from Late Palaeozoic, that involved diverse oceans of different ages (Şengör and Yilmaz, 1981; Dewey et al., 1986; Okay and Tuysuz, 1999; Robertson, 2002). Two major suture zones have been identified. The Izmir-Ankara-Erzincan suture runs along the northern part of Anatolia and represents the continuation of the Vardar suture of the Hellenides, although its tectonic evolution presents a higher degree of complexity (Okay and Tuysuz, 1999). Leaving aside the subductive evolution which produced a broad accretionary complex, the oceanic domain was finally closed in Paleocene, with thrusting continuing through the Eocene. The Bitlis suture occurs to the SE, near the Arabian platform, and belong to the peri-Arabian ophiolitic belt that continues eastward into the Zagros (Yilmaz, 1993). Along this suture, ophiolites were emplaced in Late Cretaceous, although the complete oceanic closure occurred only later, in Middle Miocene. The two suture zones are separated by the Tauride Block, which was likely a microcontinent, now incorporated within the Anatolian orogen, that is often assumed to be related to the Pelagonian Domain of the Hellenides (e.g., Şengör and Yilmaz, 1981). This correlation, however, has to be taken as dubitative, as suggested by the different age of metamorphic protoliths in the basement of the two domains, Pre-Cambrian in the Anatolian, and Carboniferous in the Pelagonian (Ring et al., 1999).

Current seismicity and focal mechanisms in Turkey outline the active deformation well (figs. 3 and 19). Besides the western part of the Anatolian Peninsula, where a diffuse seismicity is related to the Aegean Sea extensional regime, two major seismogenic zones, the Northern and the Eastern Anatolian transform faults, characterize the active deformation of Turkey (fig. 19).

The Northern Anatolian Transform Fault (NATF) is a right-lateral strike-slip fault ca. $1500 \mathrm{~km}$ long. It originated in Late Miocene, following the tightening of the collision between Arabia and Eurasia, which resulted in a lateral escape of the whole Turkish Block. The fault trace has a ENEWSW trend in its western branch and swings to ESE-WNW in the eastern branch. Quite high present-day slip rates $(>20 \mathrm{~mm} / \mathrm{yr}$ ) have been measured with the GPS technique (Kahle et al., 2000; McClusky et al., 2000). As Turkey accelerates westward in its escape with respect to stable Europe, it appears evident that the contribution of trench pull at the Hellenic subduction plays a major role in the geodynamics of this region (Cianetti et al., 1997, 2001; Meijer and Wortel, 1997; though, for a different view, see Mantovani et al., 2001). The activity of the NATF is characterised by large magnitude earthquakes, with consistent strike-slip solutions, occurring throughout the fault trace (fig. 19). Along the NATF, compressional $P$ - and extensional $T$-axes of focal mechanism solutions trend almost consistently NW-SE and NE-SW, respectively. Also the result of a moment tensor summation (both on a regular grid or on a box) shows the regularity of the transcurrent deformation occurring along this sharp structure (figs. 5, 6, 7 and 20).

The eastern end of the NATF intersects the Eastern Anatolian Transform Fault (EATF). The left-lateral NE-SW-trending EATF represents the other piece of the Turkish escaping system (Burke and Şengör, 1986; Dewey et al., 1986; Bozkurt, 2001). It is much shorter than the NATF $(550 \mathrm{~km})$ and connects the subduction near Cyprus to the East Mediterranean. Although it is much less renowned than the NATF, its kinematics is well assessed. Recent works have shown that the EATF is just the recent one (0-3 Ma) of a set of older NE-SW trending faults extending to its west (Chorowicz et al., 1999). Although seismicity along the EATF is characterised by events of lower magnitude with respect to NATF (fig. 3), the consistent strike-slip focal mechanisms, located 
throughout the tectonic structure, confirms its left-lateral motion (figs. 19 and 20). Compressional $P$ - and extensional $T$-axes trend consistently NNE-SSW and WNW-ESE respectively and the geometry of seismic deformation, obtained by moment tensor summation over the whole EATF region, confirms the left-transcurrent deformation (fig. 5). Some complexity occurs at the southwestern end of the EATF, where it enters the Mediterranean Sea, as some earthquakes with extensional focal mechanisms are recorded in the Iskenderun Gulf (fig. 19).

In the Eastern Mediterranean, the subduction of Africa continues eastward from the Hellenic trench, passing through the area of deep seismicity occurring beneath the Antalia Gulf and joining with the region south of Cyprus. Marine geophysical data show that the trench is connected to the southern branches of the EATF, where deformation is taken up by three ENE-WSW left-lateral strike-slip faults that

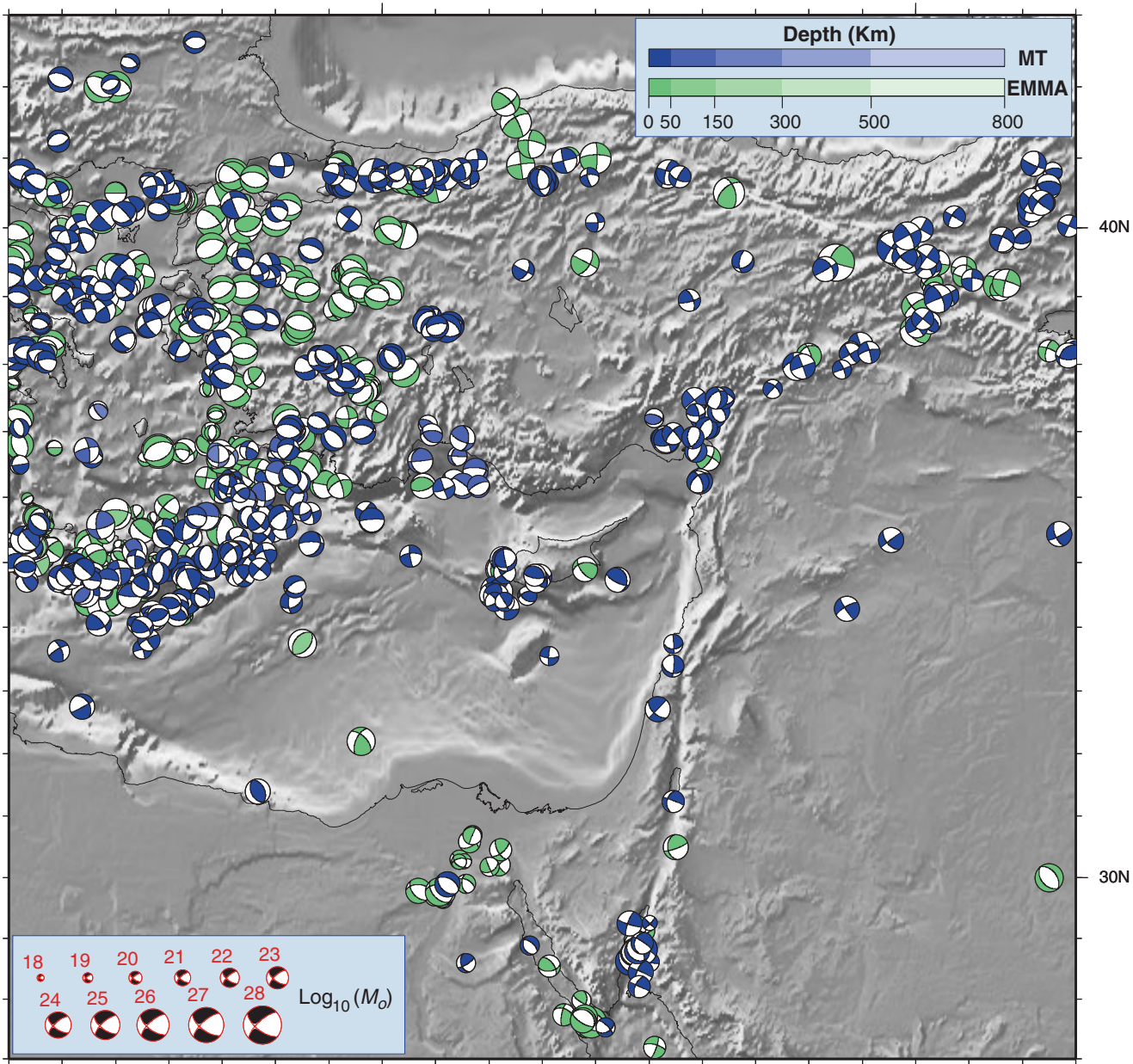

Fig. 19. Turkey, Cyprus and Sinai province. Focal mechanisms of earthquakes from MT catalogs (blue) and EMMA database (green). 


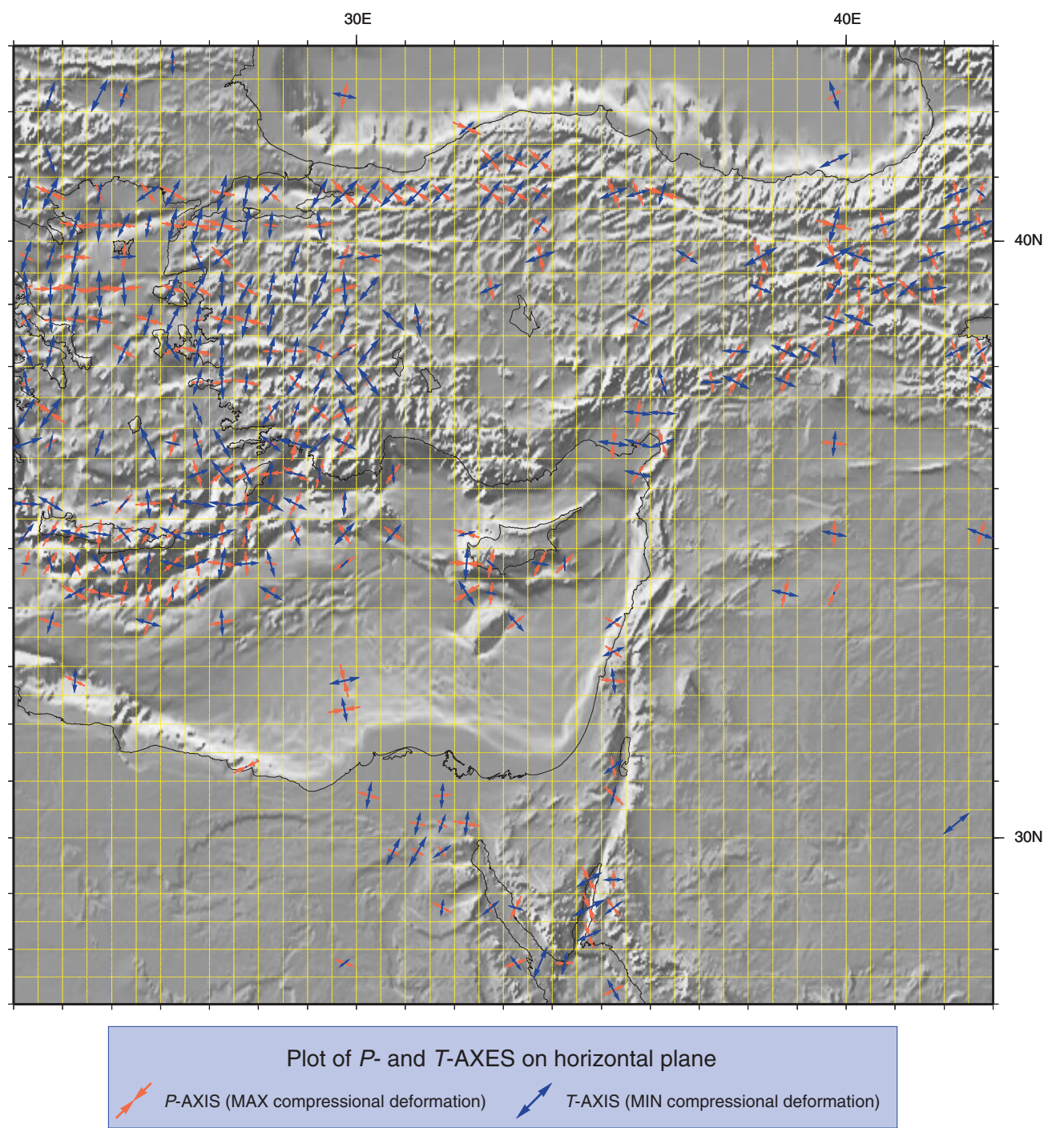

Fig. 20. Turkey, Cyprus and Sinai province. Horizontal projections of $P$ and $T$ deformation axes, on a regular grid with mesh of half a degree, derived from the sum of moment tensors (Kostrov, 1974) of earthquakes with depth $<50 \mathrm{~km}$.

merge together to the east, south of the Iskenderun Bay (Vidal et al., 2000). These strike-slip faults have a marked compressional component and might represent the kinematic solution of a strongly oblique subduction, when strain partitioning does not occur (Vidal et al., 2000). Altogether, however, the tectonic connection between the subductive boundary of the Eastern Mediterranean and the EATF is still poorly understood. Earthquakes as deep as $150 \mathrm{~km}$ and with moderate maximum magnitude are located main- 
ly around the southern part of Cyprus (figs. 3 and 4). Most focal mechanisms are for earthquakes located off-shore Western Cyprus and show thrust to strike-slip motion (fig. 19), a deformation that is probably related to the ongoing subduction of the Heratosthenes Seamount beneath the island (Mascle et al., 2000; Vidal et al., 2000).

The Eastern Anatolian plateau, which is located between the EATF and NATF, resulted from the tightening of a Late Oligocene-Early Miocene collision between the Pontide volcanic arc and Arabian Platform, that also involved the easternmost prolongation of the Tauride microcontinent (Şengör and Yilmaz, 1981; Dewey et al., 1986). In spite of an average crustal thickness of only $45 \mathrm{~km}$, this region presents a high average elevation $(>2 \mathrm{~km})$, which is supposed to be supported by a thin or absent lithospheric mantle (Şengör et al., 2003). The Late Miocene age of marine sediments in the region suggests that uplift occurred after $c a .11 \mathrm{Ma}$, being almost coeval with magmatic activity. A progressive change from calc-alkaline to transition and, finally, alkaline volcanic products, is recorded from Tortonian to Pliocene and is related to a process of slab break off (Keskin, 2003). Seismicity in this region is sparse and much reduced (fig. 3), but the few earthquake focal mechanisms show strike-slip solutions, indicating that a diffuse deformation is possibly occurring along minor strike-slip faults (figs. 19 and 20).

\section{The Dead Sea Fault Zone and the Red Sea}

The Dead Sea Fault (DSF) is a transcurrent fault that bounds the western side of the Arabia plate and that originated mainly during Early-Middle Miocene, from the separation of Arabia from Africa (Garfunkel, 1981). It is better expressed in its southern sector, where more than $100 \mathrm{~km}$ of displacement has been estimated. The seismicity is quite scarce, with maximum magnitude ranging from low to moderate and earthquake focal mechanisms display clear strike-slip solutions, supporting left-lateral motion along the fault (fig. 19). The last significant event occurred close to Jerusalem on February $11,2004, M_{w}=5.3$ and was characterized by a transtensional focal mechanism (see Quick Regional CMT at mednet.ingv.it web site). Seismicity is indeed remarkably abundant at the southern end of DSF, where some extensional focal mechanisms, with Red Sea-like extensional fault planes, also occur in the Aqaba Gulf (figs. 19 and 20). A limited amount of oceanic floor is currently created in the southern part of the Red Sea and extension is transferred to the convergent plate boundary to the north via the $1000 \mathrm{~km}$-long left DSF. The kinematics and, particularly, the amount of strikeslip motion in the northern part of the DSF are not well assessed. Seismicity is episodic and the few focal mechanisms confirm the left strike-slip motion (fig. 19). Part of the Arabia NE-ward motion has been absorbed within the Palmyride fold belt, which is a Late Palaeozoic-Mesozoic Graben inverted in three diverse episodes since Late Cretaceous, the last spanning from Early-Middle Miocene to Present, with a transpressive component (Chaimov et al., 1992; Sawaf et al., 2001). It is worth noting that only minor seismicity is present in the Palmyrides, where the focal mechanisms of a couple of events show strike-slip with N-S-trending $P$-axes, which agree with the northward motion of the Arabia plate (figs. 19 and 20).

The Gulf of Suez, which is located on the western side of the Sinai Peninsula, is about $70 \mathrm{~km}$ wide and $400 \mathrm{~km}$ long, and represents the northern termination of the Red Sea. It formed as the northernmost part of the opening Red Sea, but at about 15 Ma the Arabian plate motion was transferred along the DSF via the Aqaba Rift zone (Steckler and Ten Brink, 1986; Courtillot et al., 1987).

After that change, the motion between Africa and the Sinai Peninsula should have been negligible. Indeed, the Gulf of Suez is characterized by a seismicity with low magnitude, and although some sporadic moderate to large magnitude events occur, focal mechanisms do not show any consistent pattern (figs. 3 and 19). We should mention, however, that on the basis of marine geophysical data, it has recently been proposed that Sinai and the Levantine region behave as an independent microplate, because of a recent tectonic reorganization (Mascle et al., 2000). This platelet is bounded to the east 
by the Dead Sea transform fault, and to the west by a roughly N-S right-lateral strike-slip fault that should extend from the Gulf of Suez to west of Cyprus. Neither the distribution of seismicity, nor the solutions of focal mechanisms, however, seem to support such an interpretation.

\section{The Caucasus and the Persian province}

This broad region can be subdivided into four sectors, with respect to the almost aseismic Iranian plateau (figs. 1 and 2): a western area (Caucasus and Eastern Anatolia plateau), a northern seismic belt (South Caspian Sea and peri-Caspian zone), a southern seismic belt (Zagros), and an eastern seismic belt (Lut Block).

\subsection{Caucasus and Eastern Anatolia plateau}

This is the region where Arabia and Eurasia are closest and represents one of the most severely deformed regions of the Mediterranean. It encompasses a series of mountain belts and high plateaus that include the Greater and Lesser Caucasus, Transcaucasus, East Anatolia plateau and Bitlis suture zone (fig. 1). These elements pass to the east to the Iranian plateau.

The Caucasus region is composed of several tectonic elements that originated in a somewhat different way and with different timing. In the Greater Caucasus, deep water flysch-type sediments of Late Jurassic-Late Eocene were deformed in Late Eocene to originate a WNW-ESE-trending fold-and-thrust belt (Adamia et al., 1977; Allen et al., 2003a). These structures are still active, particularly near the southern boundary of the belt, where Plio-Quaternary strata are folded into NW-SE-elongated anticlines. Indeed, earthquakes are mainly located in the southern part of the chain and their largest magnitudes range from low to high (fig. 3). Focal mechanisms are mainly compressional, with fault planes subparallel to the structural belt, and with $P$-axes trending mainly N-NE (figs. 21 and 22). The overall present-day active compression is disclosed in the summary moment tensor, representing the seismic deformation for the whole Caucasus zone (fig. 5).

The Lesser Caucasus represents the eastern prolongation of the Izmir-Ankara-Erzincan suture zone, i.e. the suture of the Northern Neo-Tethyan branch. It is characterized by thin tectonic slivers of ophiolites and mélange rocks of Late Cretaceous age and younger sediments strongly deformed (Kocyigit et al., 2001). An Oligo-Miocene cover rests unconformably on the previously deformed units, but it is in turn folded and sealed by Plio-Quaternary sediments. A similar sedimentary and tectonic evolution is also recorded in the East Anatolia plateau. The only tectonic activity during Plio-Quaternary is given by strike-slip faulting on a conjugate set of NW-SE and NE-SW faults.

Nowadays earthquakes with strike-slip focal mechanisms dominate, in agreement with more recent tectonic structures, whereas earthquakes with compressional mechanisms are less numerous; however, all compressional $P$-axes trend almost consistently NNW (figs. 21 and 22). This geometry of deformation is also shown by the summary moment tensor computed for the whole region on a regular grid (figs. 5 to 7 ).

\subsection{South Caspian Sea and peri-Caspian zone}

The Caucasus continues to the east into the peri-Caspian deformation belt, that runs all the way around the southern part of the Caspian Sea and continues into the NW-SE-trending Kopet Dagh Belt, located north of the Lut Block (figs. 1 and 2). In the South Caspian Basin, Plio-Quaternary folding of sediments has been reported. Here earthquake focal mechanisms show mainly thrust to strike-slip mechanisms (fig. 21). It is remarkable that the distribution of both recent deformation and subcrustal 


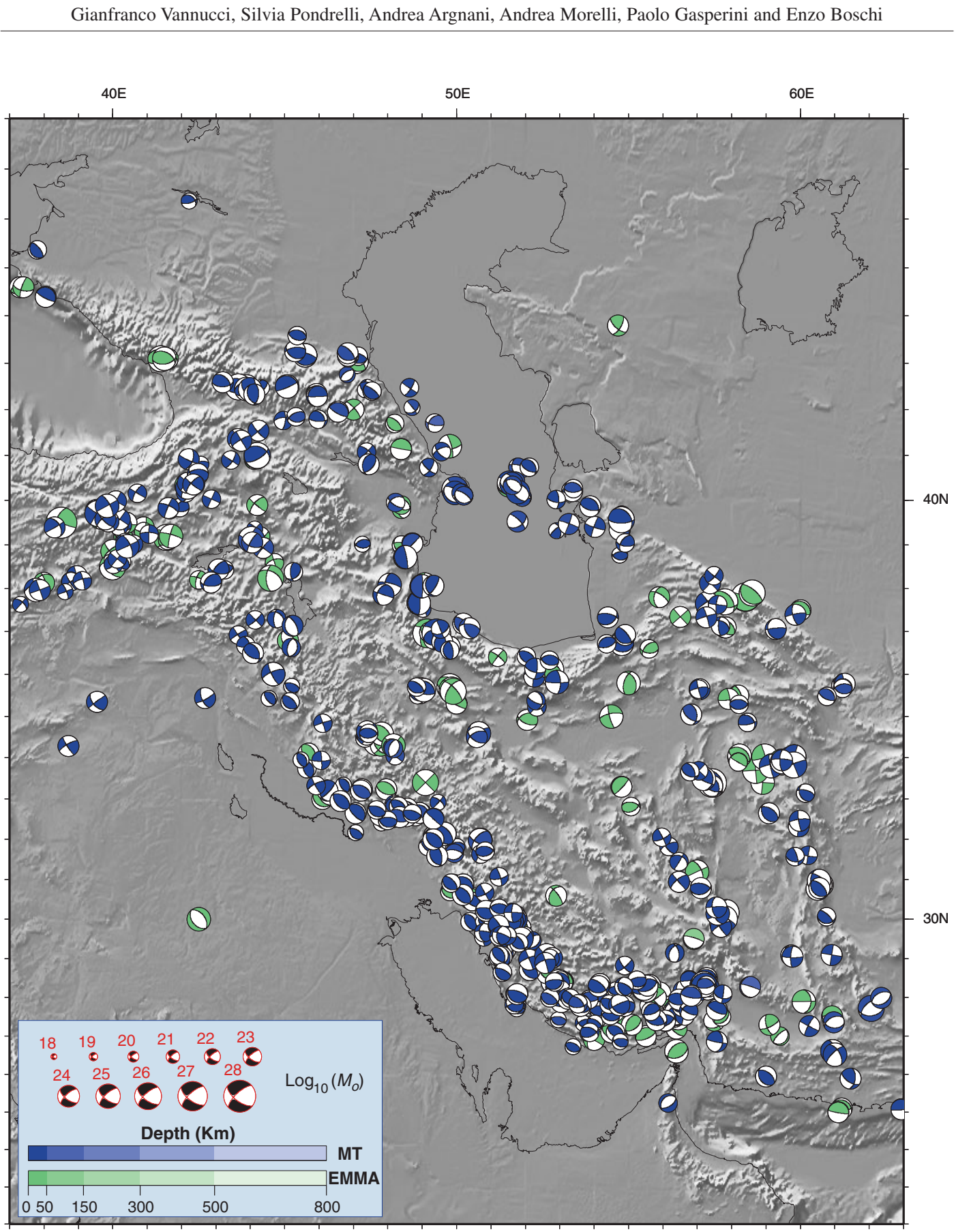

Fig. 21. Caucasus and Persian province. Focal mechanisms of earthquakes from MT catalogs (blue) and EMMA database (green). 


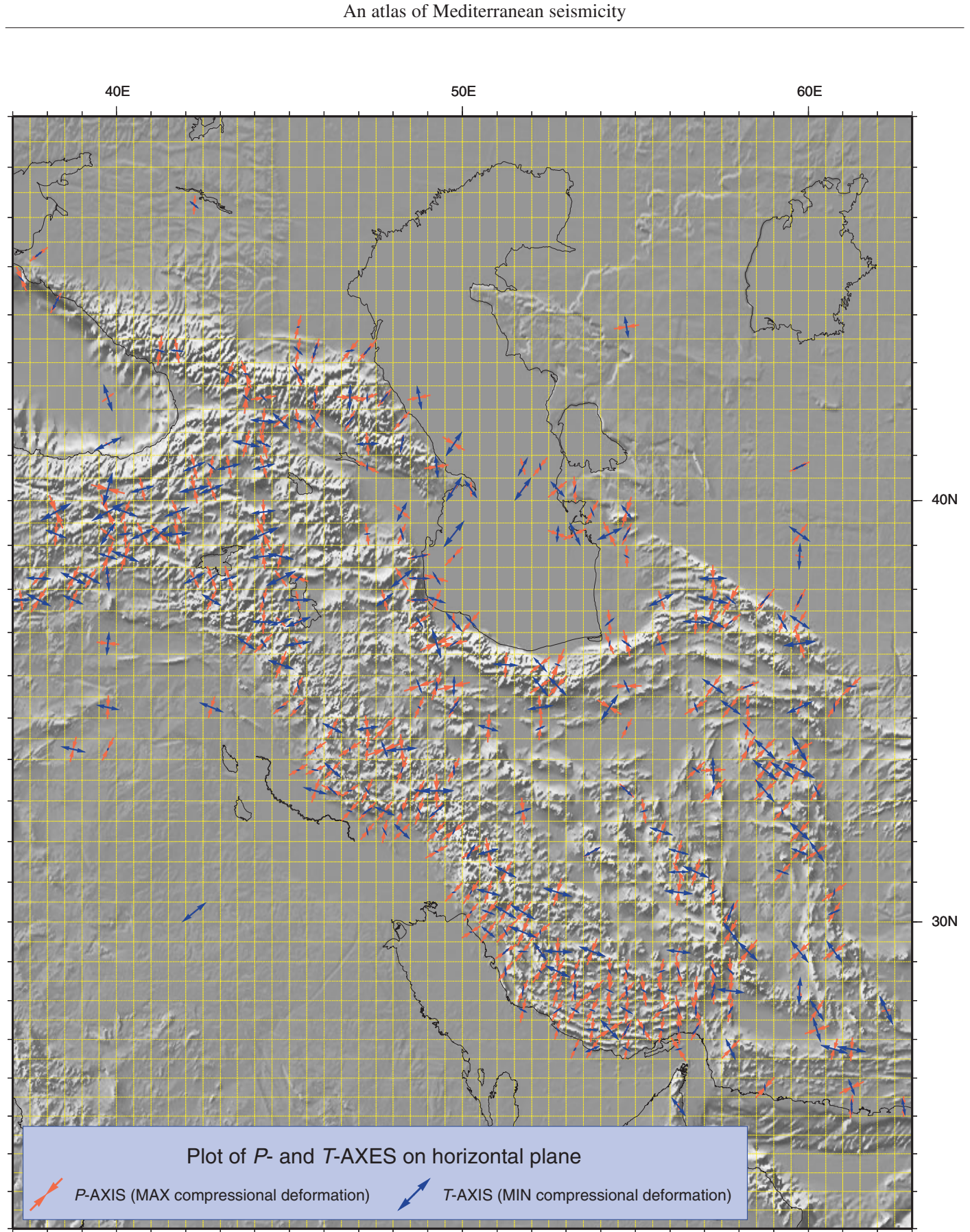

Fig. 22. Caucasus and Persian province. Horizontal projections of $P$ and $T$ deformation axes, on a regular grid with mesh of half a degree, derived from the sum of moment tensors (Kostrov, 1974) of earthquakes with depth $<50 \mathrm{~km}$. 
earthquakes (figs. 3 and 4) lead to the hypothesis that the South Caspian Block is currently subducting underneath its northern and western boundaries (Allen et al., 2002). Moreover, where deep earthquakes are located across the Caspian Sea, a submarine relief (Apsheron Sill) is connecting the Great Caucasus with the Kopet Dagh. On the other hand, at present, the distribution of seismic data could not confirm the subduction. The whole seismic deformation shows a thrust summary moment tensor, with a NE-SW trending compressional $P$-axis (figs. 5 to 7 ).

The western part of the peri-Caspian zone is constituted by the Talesh Belt, characterised by Mesozoic to Oligocene marine sediments with deep water flysch and volcanoclastics in Palaeocene-Eocene, and turbidites in Oligocene. Folding and thrusting has affected this range since Pliocene-Quaternary and are still active (Allen et al., 2003a), as confirmed by mostly thrust earthquake focal mechanisms (fig. 21). Compressional $P$-axes are striking from $\mathrm{N}$ to $\mathrm{WNW}$, remaining often perpendicular to the structure of the belt.

In the Alborz region (fig. 1; Stocklin, 1968; Allen et al., 2003b) it is possible to find the traces of a Late Triassic closure of Paleo-Tethys, followed by Jurassic and Cretaceous mainly shallow-marine sedimentation, which characterizes this region. The clastic Cenozoic sediments are dominated by a thick Eocene succession characterised by turbidites and volcanoclastics, followed by coarsening and shallowing upwards sedimentation during Oligo-Miocene. This last trend can be related to the progressive compression occurring within the Arabia-Eurasia collision. Folding was subsequently accompanied by left-lateral strike-slip on ENE-WSW and WNW-ESE faults, on the east and west of the range respectively. Here indeed, with respect to western and northern areas, strike-slip focal mechanism solutions are frequent (fig. 21). Despite shortening and convergence, the crust of the Alborz Belt has the same thickness $(35 \mathrm{~km})$ as the adjacent regions, and magmatic and volcanic activity is fairly young, less than $7 \mathrm{Ma}$.

In the Kopet Dagh (fig. 1), continuous marine sedimentation occurred from Jurassic to Eocene and, with minor hyatuses, until Miocene. Subsequently, Alpine folding occurred from Late Miocene through Plio-Quaternary (Stocklin, 1968; Lyberis and Manby, 1999; Allen et al., 2003a).

The Iranian plateau is bounded by two seismic deformation belts, where seismicity is frequent, with largest magnitude ranging from low to moderate (fig. 3). The northern belt trends WNW-ESE and includes the Greater Caucasus, Apsheron Sill and northern part of the Kopet Dagh. Focal mechanisms are both compressional with fault planes subparallel to the belt and strike-slip (fig. 21). Some of the strike-slip events line up along the sharp northern boundary of the Kopet Dagh, the Ashgabat Fault (AhSF) supporting its right-lateral motion. Trends of $P$-axes vary from N-S to NE-SW (fig. 7). The southern belt runs around the South Caspian Sea and includes the Lesser Caucasus, Talesh, Alborz and the southern part of the Kopet Dagh. Earthquake focal mechanisms are both compressional and strike-slip, with fault planes that vary according to the trend of the belt. $P$-axes direction shows a wide variability, passing from E-W in the western part, to NE-SW in the Central part, and finally to NNW-SSE in the Eastern part, following the main structure of the chain (fig. 21).

\subsection{Zagros region}

The Zagros is a southwest-vergent NW-SE trending mountain belt, which runs from the Caucasus region to Southern Pakistan (fig. 1; National Iranian Oil Company, 1959; Stocklin, 1968; Alavi, 1994; Allen et al., 2004), where it ultimately joins the Himalayas to the north. In the internal part of the belt, oceanic mélanges with ophiolites of Late Cretaceous-Early Tertiary, mark a suture zone that represents the eastward continuation of the Bitlis suture of East Turkey. The suturing between Arabia and Eurasia likely occurred in Early Miocene.

Recent tectonics and seismicity in the Zagros is mainly restricted to the outermost part of the belt, the so-called Simple Folded Belt (Colman-Sadd, 1978), that fringes the northern margin of the Ara- 
bian plate and that is made up by sediments belonging to the former Arabian passive margin, folded and thrusted since Pliocene. Seismic activity in this region is highly frequent, with numerous moderate to large magnitude earthquakes (fig. 3). Almost all focal mechanisms are compressional and only a small part is strike-slip (fig. 21). On average, all of them show a compressional $P$-axis perpendicular to mountain range. As a consequence, also the summary moment tensor for this region is a quite pure thrust, with compressional $P$-axis NE-SW trending (figs. 5 to 7 ). Seismic data suggest that shortening across the belt occurred by distributed basement thickening on high angle reverse faults (Jackson and Fitch, 1981; Berberian, 1995), although at present a decollement at the base of the thick sedimentary cover cannot be ruled out (McQuarrie, 2004). This very long mountain belt, $c a$. 1500 $\mathrm{km}$, presents some changes in structural direction. From the main NW-SE trend, the fold-and-thrust axes swing to E-W in the south and in the north, lining around the Arabian craton. The Simple Folded Belt is separated by the more internal terranes, made up by volcanic and metamorphic rocks, including ophiolites, by a major structure, known as the Main Zagros Thrust (MZT). Strike-slip motion occurs along the northern segment of the MZT as part of the partition, together with orthogonal shortening in the NW part of the Simply Folded Belt, of the oblique Arabia-Europe convergence (Berberian, 1995; Talebian and Jackson, 2004). These trends are also confirmed by seismicity distribution and focal mechanism characteristics: some earthquakes with strike-slip focal mechanisms occur where the trend of the fold-and-thrust belt is oblique to the roughly N-S Arabia-Eurasia convergence, in the central and northern part of the Zagros (fig. 21). In particular, where the mountain belt trend changes from E-W in the Southern Zagros to NW-SE further to the north, strike-slip faults occur in close proximity to thrusting, to define a complex accommodation system with faults interpreted to rotate around vertical axes (Talebian and Jackson, 2004). Focal mechanisms also show that the Zagros Belt merges to the north into the Eastern Anatolian region, showing a progressive change towards the domain of conjugate strike-slip faults that diffusely cover the area south of the Caucasus (fig. 21).

\subsection{Lut Block}

To the east, the Zagros joins the complex deformation that wraps around the stable Lut Block, or Dasht-i-Lut Block (fig. 1; National Iranian Oil Company, 1959; Stocklin, 1968). Late CretaceousPalaeocene accretionary complexes, including ophiolites and forearc terranes, crop out along the northern and eastern side of the Lut Block, recording the Late Eocene suture between the Lut and Afghan blocks (Tirrul et al., 1983). The N-S elongated Lut Block is currently surrounded by tectonic structures displaying a great variety of directions, but mainly trending parallel to the block boundaries that originated in the subsequent progression of collision. The Lut Block also represents the eastern boundary of the aseismic Iranian plateau. Seismicity is distributed all around the block, particularly close to its corners, with earthquakes of moderate to large maximum magnitude (fig. 21). The most recent great earthquake experienced by this region is the Bam event, that occurred close to the SW corner of the Lut Block on December 26, 2003, $M=6.6$, killing more than 26000 people and leaving more than $85 \%$ of buildings destroyed. Usually, earthquake focal mechanisms for this region are both compressional and strike-slip (fig. 21). The abundance of focal mechanisms, which agree with a N-S right-lateral strike-slip, supports the view that a dextral transfer of deformation occurs along this boundary. In fact, this region of complex deformation represents the transition between the subduction of the Indian Ocean underneath the Makran accretionary complex, where most of deformation is absorbed and the more widespread continental deformation in the Iranian region. The Lut Block also represents the transition from the deforming Iranian region and Western Afghanistan, which is part of stable Europe. In a simplified way, the deformation can be described by a right-lateral shear along N-S-trending dextral strike-slip faults at the eastern and western side of the block.

The region located to the west of the Lut Block, and bounded by the Alborz and Zagros to the north and south respectively (fig. 1), is characterised by thickened crust (45-50 km) and high eleva- 
tion $(>2 \mathrm{~km})$ and represents the continuation of the East Anatolia plateau. In this region a system of strike-slip faults (left-lateral NE-SW Great Kavir Fault - GKF, and right-lateral NW-SE Deh Sir Fault - DhSF) accommodated the indentation-driven eastward escape of Central Iran. The activity of these faults has been dated as mostly Post-Miocene in age. It is worth noting that no current seismic activity occurs along the fault system that has been interpreted to drive the eastward escape of Central Iran (National Iranian Oil Company, 1959; Bonini et al., 2003).

\section{Continental Europe}

Seismicity in continental Europe is certainly less and of lower energy compared to the seismic activity of the Mediterranean region (fig. 3). Moreover, this area covers a wide variety of geological elements, often not related one to the other, that have in common a limited neotectonic activity. The low level of seismicity, both in intensity and number of events, and the variability of focal mechanisms within the same sector, point to characterizing these geological features as on the way to be progressively deactivated. However, although far away from the main Africa-Eurasia plate boundary, some areas affected by diffused seismicity with few and rare large magnitude earthquakes should be addressed. The main areas of interest in this broad region include the Pyrenees, Rhine Graben, Western Europe Massives (Armorican and Central), and Vrancea (figs. 1 and 2).

\subsection{The Pyrenees}

The Pyrenees are a collisional belt originated by convergence, and partly strike-slip, between Iberia and Europe from Late Cretaceous to Early-Middle Miocene. Although asymmetrical, the Pyrenees are a double verging mountain range, with the southern side more developed. Foreland basins occur on either side of the chain, filled with sediments of Late Cretaceous to Paleogene age. The estimated shortening is about $170 \mathrm{~km}$, mostly at the expense of the Iberian plate, and it is assumed that no oceanic substrate was involved. Following the Middle Miocene end of collision, Iberia moved together with Europe. In agreement with this picture, current seismicity of Pyrenees is of moderate energy, with only rare events with magnitude greater than 5.0 (figs. 3 and 23). Most of the seismic activity is located in the western part of the mountain range and focal mechanisms show mainly strike-slip and extensional geometries, with heterogeneous directions (fig. 23). The lack of compressional events is remarkable because it testifies the shutting down of orogenic activity.

\subsection{The Rhine Graben}

The Rhine Graben is part of the European Tertiary rift system that extends from the Gulf of Lyon and Rhone Graben to the North Sea (Ziegler, 1992). The graben is 30-40 km wide and ca. 300 $\mathrm{km}$ long and is underlined by a Moho shallower $(24 \mathrm{~km})$ than the adjacent regions $(30 \mathrm{~km})$. Rifting occurred from Late Eocene to Early Miocene and subsequently passed, in the southern part, to a tectonic regime where shoulder uplift dominates, culminating in a Plio-Pleistocene transpressional reactivation of the Southern Rhine Graben, likely due to the progressive indenting of Adria. On the other hand, limited subsidence continued in the northern part of the graben during Mio-Pliocene. Present day seismicity is frequent but mostly of low magnitude $(M<4.0)$, although some large earthquakes occurred in the Southern Rhine Graben. Focal mechanisms are mainly strike-slip, particularly in the southernmost part of the graben, with some extensional solutions (fig. 23). Altogether, the current tectonic regime appears transtensional and the NW-trending $P$-axes suggest a contribution from Alpine compression (Carey-Gailhardis and Mercier, 1992; Giamboni et al., 2004). Near 


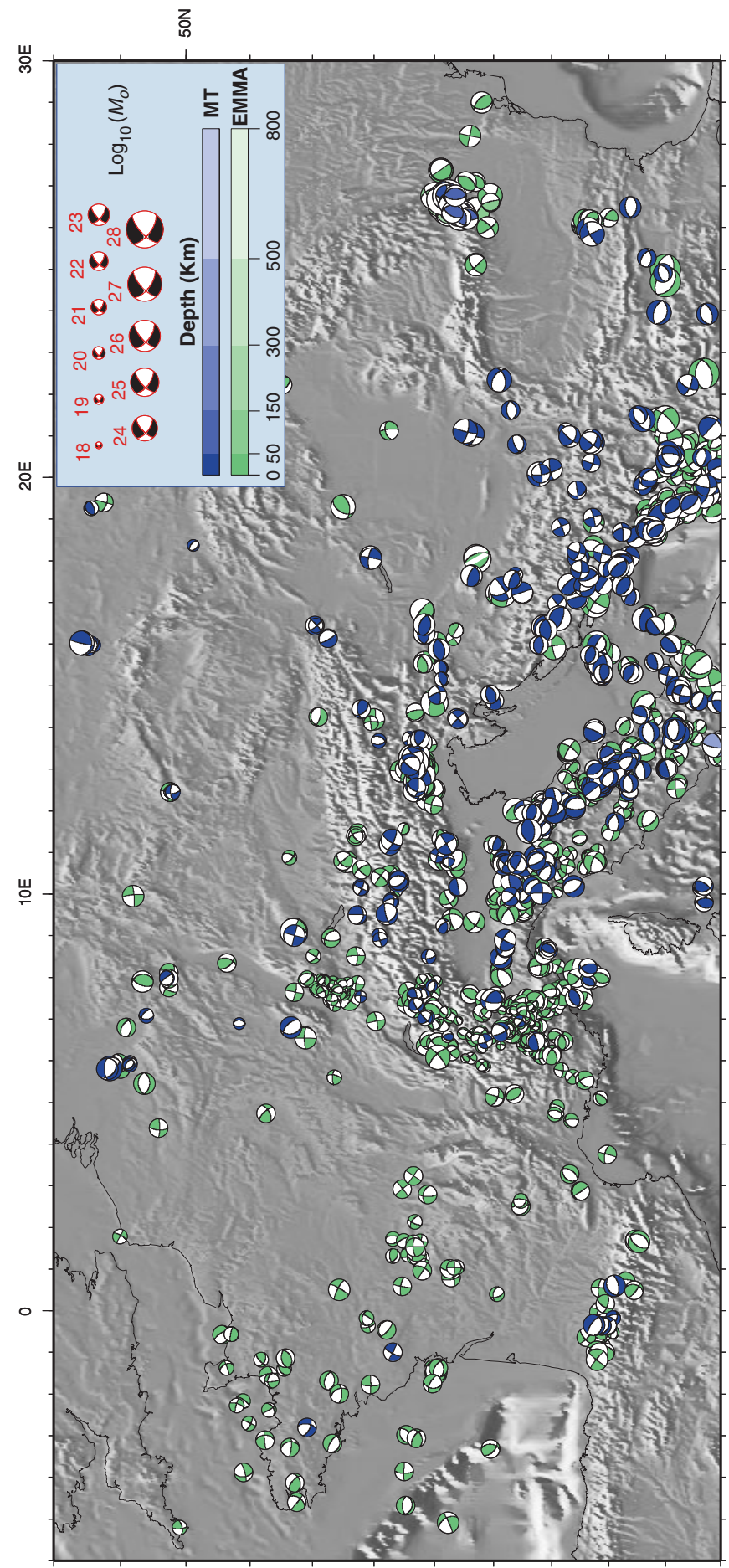

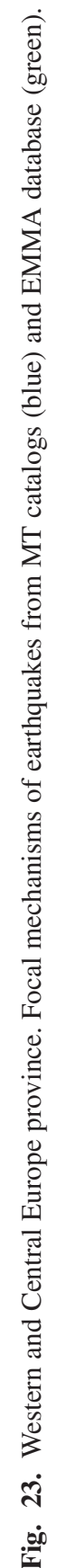


Frankfurt, the northern part of the Rhine Graben is connected with two branches of the European Tertiary rift system. The branch that trends N (Leine Graben) is aseismic and is tectonically quiescent, whereas the branch trending NW (Ruhr Graben) is seismically active. Here, few large magnitude events occurred (e.g., the 1992 Roermond, Netherlands, $M_{L}$ 5.8), despite the near absence of low magnitude seismicity, and focal mechanisms are mainly extensional (figs. 3 and 23).

\subsection{Western Europe: Central and Armorican massifs}

Western and Central Europe are characterised by the presence of several epicontinental basins that originated during the Mesozoic, or even since Palaeozoic, with the North Sea Graben as the most noticeable example. Several of these extensional basins were subsequently inverted (sometimes only partly) during Alpine collision, often in repeated events (Ziegler, 1990). Timing and spatial distribution of Alpine inversion in Western Europe appear rather patchy, suggesting that the region was prone to deformation whenever the structures presented the right orientation (Ziegler, 1990). Besides Cenozoic rifting and tectonic inversion, Western and Central Europe was also the site of Neogene-Quaternary alkaline magmatism, particularly in the Massif Central, Eger Graben and northern part of the Rhine Graben (Wilson and Downes, 1992). On the other hand, deformation was almost everywhere rather limited, indicating that remote stresses were only moderate. Current seismicity in this part of Europe is frequent but of low energy and is concentrated mainly in the Central and Armorican massifs (figs. 3 and 23). Seismic deformation in the Central Massif is characterised by a strike-slip regime, depicted by focal mechanisms (figs. 6, 7, and 23), with $P$-axes trending roughly N-NW. In the Armorican Massif, instead, the heterogeneity of focal mechanisms does not reveal any clear tectonic pattern (fig. 23).

\subsection{The Carpathian Arc}

In Eastern Europe, the area where a certain amount of seismicity is occurring is the Carpathian Arc. The evolution of the Carpathians has been controlled by passive sinking and rollback, from upper Oligocene to Pliocene, of a lithosphere over which the Rhenodanubian-Carpathian Flysch was deposited. Such a lithosphere was likely oceanic and is now present as a seismic slab at depth (Fan et al., 1998). A progressively younger age of the thrust front towards SE has been observed along the Eastern Carpathians towards the Vrancea, and also the age of onset of the foredeep basin becomes progressively younger in the same direction (Royden, 1988; Meulenkamp et al., 1996).

Moreover, linear zones of basaltic andesites, located at the boundary between inner and outer Carpathians, become progressively younger from $c a$. 16-14 Ma in the Western Carpathians to 4-0 Ma in Vrancea (Nemcok et al., 1998). This SE-ward migration of events along the Eastern Carpathians marks the steps of subduction retreat and lateral tearing of the slab (Royden, 1988; Linzer, 1996; Meulenkamp et al., 1996; Nemcok et al., 1998). The Vrancea region represents the apex of the Carpathian Arc, where deformation progressively focused in time, throughout the MioPliocene evolution of the entire Carpathian-Pannonian region. Recent tectonics is characterised by dominant vertical motion, resembling to some extent the Calabrian Arc tectonics. It also seems that NW-SE-trending strike-slip faults have contributed to the most recent advancement of the apex of the Carpathian Arc. The occurrence of a very steep descending slab is testified by the deep (up to $250 \mathrm{~km}$ ) and highly frequent large magnitude seismicity (figs. 23 and 24). However, it is worth noting that deep earthquakes are mainly concentrated in a depth interval that ranges between 80 and about $180 \mathrm{~km}$ (fig. 24). Focal mechanisms, mainly thrust or strike-slip, are mainly obtained from these deep events, whereas the limited crustal earthquakes do not disclose any clear tectonic pattern. In fact, besides subduction-related seismic activity, the Carpathian region is affected only by minor earthquakes (figs. 3 and 4). 

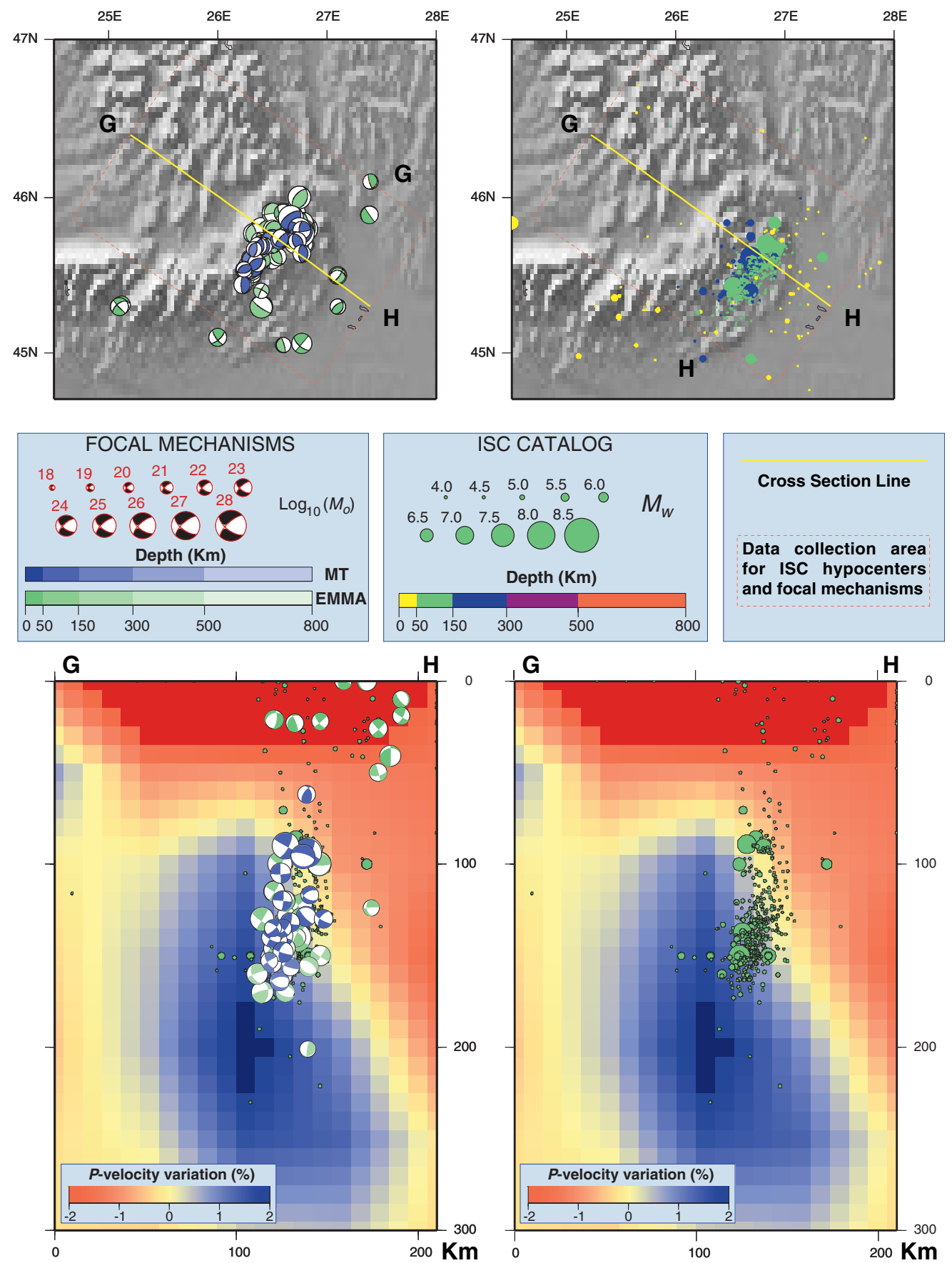

Fig. 24. Cross section of the Vrancea region: depth distribution of instrumental seismicity (from ISC Catalog) and focal mechanisms from EMMA database (green) and MT catalogs (blue). 

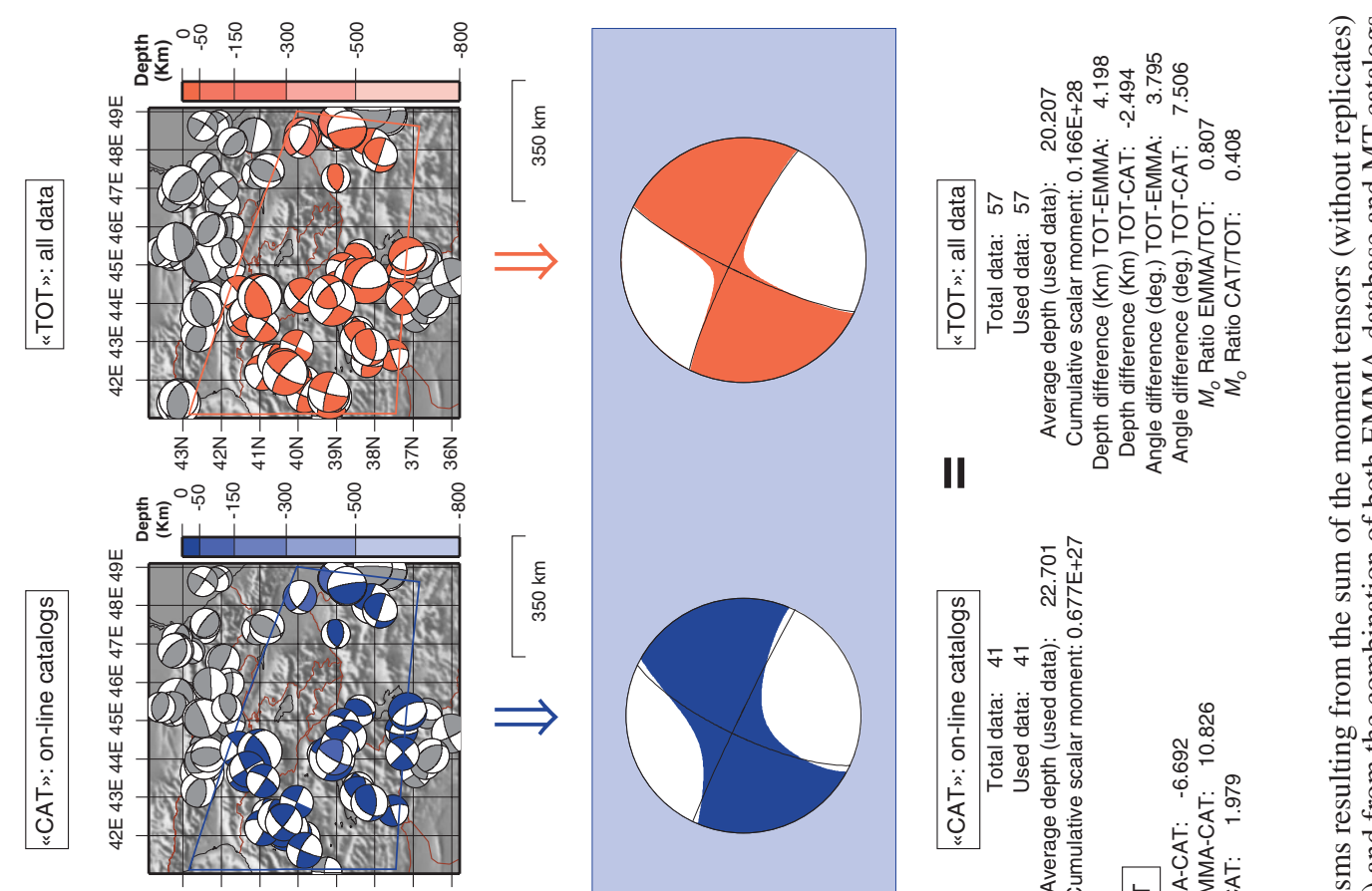

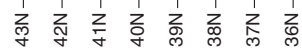

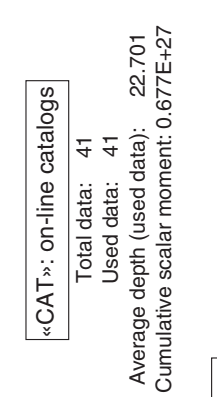

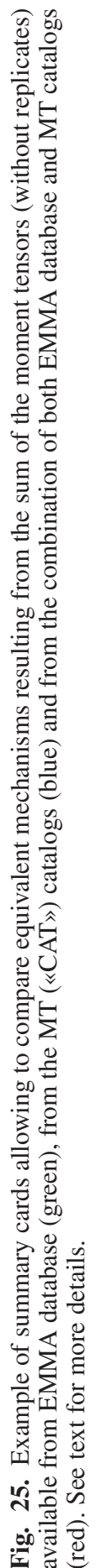
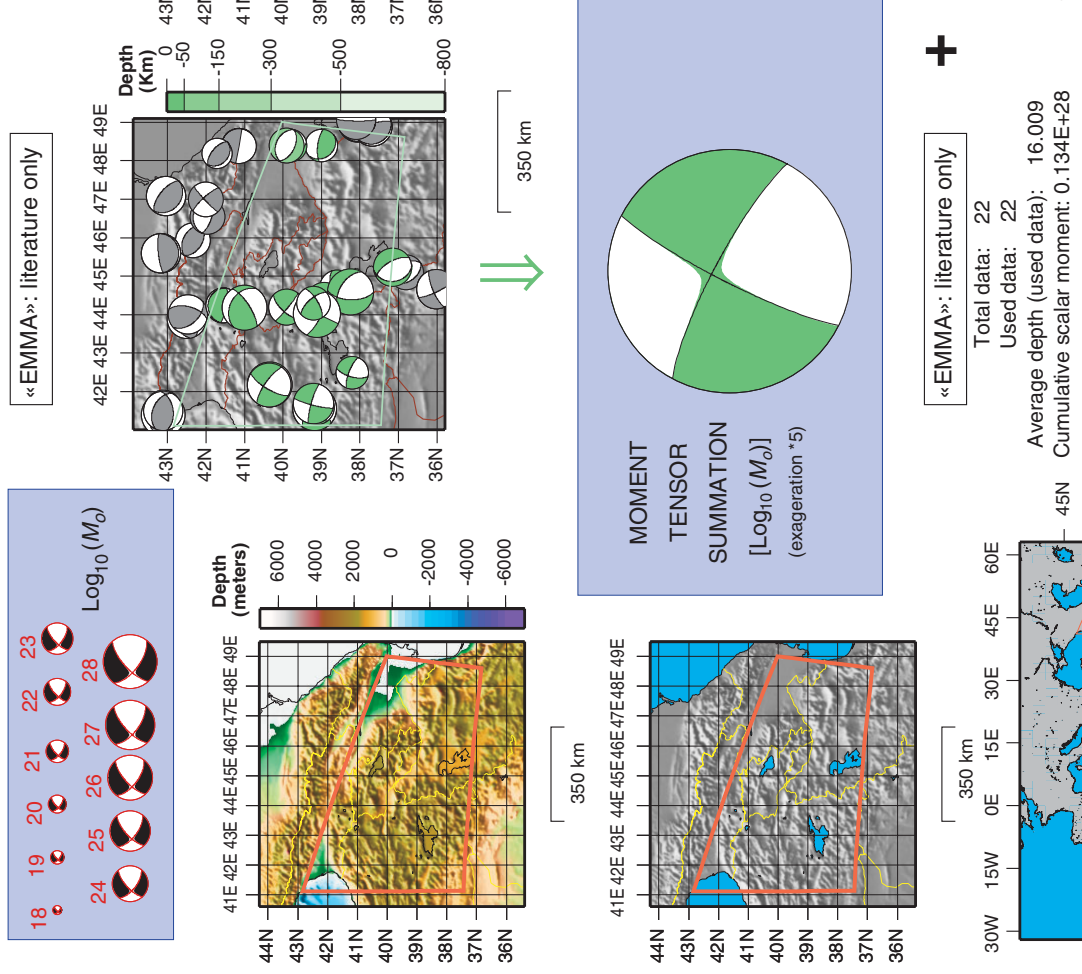


\section{CONCluding REMARKS}

The maps shown in this article illustrate the complexity of earthquake geometry and occurrence patterns in the Alpine Mediterranean region. Within the limits of these pages we only provide a large scale picture of the Mediterranean seismicity. For further analyses, we provide extensive additional material in an enclosed CD-ROM. Electronic material includes earthquake data, used in this work - the EMMA database (see Vannucci and Gasperini, 2004), the European-Mediterranean RCMT Catalog (Pondrelli et al., 2002, 2004a) - and a complete collection of maps - displaying focal mechanisms and deformation axes of individual events, and moment tensor sums over different regions. Maps for many geographical regions, with different selections of data, can be visualized and printed. This material and EMMA database (and future improvements) can be found respectively at http://ibogfs.df.unibo.it/user6/www_data/emma.html and www.ingv.it/seismoglo/atlas web address.

The CD-ROM also contains an extensive collection of summary cards (see, e.g., fig. 23) that report, for each given zone, the mechanisms resulting from the sum of all of the moment tensors (without duplications) available from the EMMA database alone, the moment tensor catalogs alone (also with duplicates removed), and from a combination of both EMMA database and moment tensor catalogs. Summary cards give a visual and quantitative comparison of the relative contribution given by the EMMA database alone, the moment tensor catalogs, and a combination of the two kinds of data source. They also show maps of the focal mechanisms, as well as some summary indicators, useful to evaluate the relative coherency of the different datasets. In particular, we indicate the total number of mechanisms available for the given area, the number of actually «used» mechanisms (i.e. belonging to a given depth interval), the average source depth and the cumulative scalar moment, computed as the scalar moment of the double couple which best fits the cumulative moment tensor (the average of the two largest moment eigenvectors in modulus). To evaluate the reliability and coherency of the different datasets, we also compute and report on the cards some further quantities like the average depth difference, the ratios between cumulative scalar moments and the minimum rotation angle between best double couples (Kagan, 1991). The latter is the measure of the misalignment between the dihedrons (couple of planes) representing the best double couples of two mechanisms. Its value ranges from $0^{\circ}$, corresponding to a perfect coincidence, to $120^{\circ}$, indicating the maximum divergence (Kagan, 1991). An acceptable agreement is represented by angles of the order of some tens of degrees, while a strong variance is given by angles larger than $50^{\circ}-60^{\circ}$. We compiled a summary card for each of the seismogenic zones reported in fig. 25, and for all of the non-empty rectangular cells drawn over a regular grid with $1^{\circ} \times 1^{\circ}$ mesh, both in latitude and in longitude. A sensitive map allows them to be accessed by clicking on the corresponding red cells. For green cells, which contain mechanisms from EMMA only, and for blue cells, which contain mechanisms from online catalogs only, a comparison is not possible. For the two areas with highest density of data (Italy and Greece) a further subdivision with cell size by half a degree is also provided. For Italy we make summary cards accessible for the boxes of the most recent seismogenic zonation ZS9 (ZS9 Working Group, 2004).

Geodynamic models and detailed descriptions of seismogenic areas at the scale of fault zones are outside the goals of this contribution. We instead restricted ourselves to presenting the information content of available datasets of earthquake data. These data provide a wealth of information on active tectonics, that the interested reader can easily retrieve using databases and tools from the CD-ROM, zooming in areas of specific interest.

\section{REFERENCES}

Abbate, E. and M. SAgRi (1970): The eugeosynclinal sequences, in Development of the Northern Apennines Geosyncline, edited by G. Sestini, Sediment. Geol., 4 (special issue), 251-340.

AdAmiA, Sh.A., M.B. LordKIPANIDZE and G.S. ZAKARIADZE (1977): Evolution of an active continental margin as exemplified by the Alpine history of the Caucasus, Tectonophysics, 40, 183-199. 
Alavi, M. (1994): Tectonics of the Zagros orogenic belt of Iran: new data and interpretations, Tectonophysics, 229, 211-238.

Allen, M.B., S. Jones, A. Ismail-Zadeh, M. Simmons and L. Anderson (2002): Onset of subduction as the cause of rapid Pliocene-Quaternary subsidence in the South Caspian Basin, Geology, 30, 775-778.

Allen, M.B., S.J. Vincent, G.I. Alsop, A. IsMAIL-ZADEH and R. FleCKer (2003a): Late Cenozoic deformation in the South Caspian region: effects of a rigid basement block within a collision zone, Tectonophysics, 366, 223-239.

Allen, M.B., M.R. Ghassemi, M. Shahrabi and M. Qorashi (2003b): Accommodation of late Cenozoic shortening in the Alborz range, Northern Iran, J. Struct. Geol., 25, 659-672.

Allen, M.B., J. JACKSON and R. WALKer (2004): Late Cenozoic reorganization of the Arabia-Eurasia collision and the comparison of short-term and long-term deformation rates, Tectonics, 23, TC2008, doi:10.1029/2003TC001530.

Alvarez, W. (1976): A former continuation of the Alps, Geol. Soc. Am. Bull., 87, 891-896.

Alvarez-Marron, J. (1999): Pliocene to Holocene structure of the eastern Alboran Sea (Western Mediterranean), in Proceedings of the Ocean Drilling Program, Scientific Results, vol. 161, 345355.

Amato, A. and G. Selvaggi (1993): Aftershock location and $P$-velocity structure in the epicentral region of the 1980 Irpinia earthquake, Ann. Geofis., XXXVI (1), 3-15.

Amodio-Morelli, L., G. Bonardi, V. Colonna, D. Dietrich, G. Giunta, F. Ippolito, V. Liguori, S. Lorenzoni, A. Paglionico, V. Perrone, G. Piccarreta, M. Russo, P. Scandone, E. Zanetti-LoRENZONI and A. ZuPPETTA (1976): L'Arco Calabro-Peloritano nell'orogene appenninico-maghrebide, Mem. Soc. Geol. It., 17, 1-60.

Amoruso, A., L. Crescentini and R. Scarpa (2002): Source parameters of the 1908 Messina Straits, Italy, earthquake from geodetic and seismic data, J. Geophys. Res., 107 (B4), 2080.

Argnani, A. (1987): The Gela Nappe: evidence of accretionary melange in the Maghrebian foredeep of Sicily, Mem. Soc. Geol. It., 38, 419-428.

Argnani, A. (1990): The Strait of Sicily Rift Zone: foreland deformation related to the evolution of a backarc basin, J. Geodyn., 12, 311-331.

Argnani, A. (2000a): The southern Apennines-Tyrrhenian system within the kinematic frame of the central Mediterranean, Mem. Soc. Geol. It., 55, 115-122.

Argnani, A. (2000b): The Southern Tyrrhenian Subduction System: Recent Evolution and Neotectonic Implications, Ann. Geofis., 43 (3), 585-607.

Argnani, A. (2002): The northern Apennines and the kinematics of Africa-Europe convergence, Boll. Soc. Geol. It., spec. vol. (1), 47-60.

Argnani, A. and F. FrugONI (1997): Foreland deformation in the Central Adriatic and its bearing on the evolution of the Northern Apennines, Ann. Geofis., XL (3), 771-780.

Argnani, A. and C. Piromallo (2003): The evolution of the Alpine orogen of Eastern Europe: insights from plate kinematics and comparison with mantle tomography, 10-12 Febbraio 2003, Trieste, Mem. Sci. Geol., 54, 83-86.

ARGNANI, A. and F. RiCCI LUCCHI (2001): Tertiary siliciclastic turbidite systems, in Anatomy of a Mountain: the Apennines and Adjacent Mediterranean Basins, edited by G.B. VAI and I.P. MARTINI (Kluwer Academic Publisher, London), 327-350.

Argnani, A. and C. SaVelli (2001): Magmatic signature of episodic backarc rifting in the Southern Tyrrhenian Sea, in PeriTethys Memoir 6: Rift/Wrench Basins and Passive Margins, edited by P. Ziegler, W. Cavazza, A.H.F.R. Robertson and S. Crasquin-Soleau, Mem. Mus. Hist. Nat., 186, $735-754$

Argnani, A. and L. Torelli (2001): The Pelagian shelf and its graben system, in PeriTethys Memoir 6: Rift/Wrench Basins and Passive Margins, edited by P. ZIEGLER, W. CAVAZZA, A.H.F.R. RoBertSon and S. Crasquin-Soleau, Mem. Mus. Hist. Nat., 186, 529-544. 
Argnani, A., P. Favali, F. Frugoni, F. Gasperini, M. Ligi, M. Marani, G. Mattietti and G. Mele (1993): Foreland deformational pattern in the Southern Adriatic Sea, Ann. Geofis., XXXVI (2), 229-247.

Argnani, A., C. Bonazzi, D. Evangelisti, P. Favali, F. Frugoni, M. Gasperini, M. Ligi, M. MaraNI and G. Mele (1996): Tettonica dell'Adriatico Meridionale, Mem. Soc. Geol. It., 51, 227-237.

Argnani, A., M. Bernini, G.M. Di Dio, G. PAPAni and S. Rogledi (1997): Stratigraphic record of crustal-scale tectonics in the Quaternary of the Northern Apennines (Italy), Il Quaternario, 10, 595-602.

Argnani, A., C. BonAzZI and THE MESC 2001 CREW (2002a): Tectonics of Eastern Sicily offshore: preliminary results from the MESC 2001 marine seismic cruise, Boll. Geofis. Teor. Appl., 43 (3/4), 177-193.

Argnani A., C. BonAzZI and P. Costa Pisani (2002b): Neogene deformation in the central Adriatic Sea, in RealMod 2002, 2-4 October 2002, Milano, 135-138

ARvidsson, R. and G. EKSTRÖM (1998): Global CMT Analysis of moderate earthquakes $M_{W}>4.5$ using intermediate period surface waves, Bull. Seismol. Soc. Am., 88, 1003-1013.

Aubouin, J. and I. Ndojaj (1964): Regard sur la geologie de l'Albanie et sa place dans la geologie des Dinarides, Bull. Soc. Geol. Fr., 7, 593-625.

Aubouin, J., R. Blanchet, J-P. Cadet, P. Celet, J. Charvet, J. Chorowicz, M. Cousin and J-P. RAmpNoux (1970): Essai sur la geologie des Dinarides, Bull. Soc. Geol. Fr., 6, 1060-1095.

BANKS, C.J. and J. WARBURTON (1991): Mid-crustal detachment in the Betic system of Southern Spain, Tectonophysics, 191, 275-289.

Barberi, F., F. Innocenti, G. Ferrara, J. Keller and L. Villari (1974): Evolution of Eolian Arc volcanism (Southern Tyrrhenian Sea), Earth Planet. Sci. Lett., 21, 269-276.

Bartolini, C., M. Bernini, G.C. Carloni, A. Costantini, P.R. Federici, G. Gasperi, A. Lazzarotto, G. Marchetti, R. Mazzanti, G. Papani, G. Pranzini, A. Rau, F. Sandrelli, P.L. Vercesi, D. Castaldini and F. Francavilla (1982): Carta neotettonica dell'Appennino Settentrionale. Note illustrative, Boll. Soc. Geol. It., 101, 523-549.

Battaglia, M., M.H. Murray, E. Serpelloni and R. Buergmann (2004): The Adriatic region: an independent microplate within the Africa-Eurasia collison zone, Geophys. Res. Lett., 31, L09605, doi: 10.1029/2004GL019723.

Ben Avram, Z. and A. Nur (1976): Slip rates and morphology of continental collision belts, Geology, 4, 661-664.

Benetatos, C., A. Kiratzi, C. Papazachos and G. Karakaisis (2004): Focal mechanisms of shallow and intermediate depth earthquakes along the Hellenic Arc, J. Geodyn., 37, 253-296.

BERBERIAN, M. (1995): Master «blind» thrust faults hidden under the Zagros folds: active basement tectonics and surface morphotectonics, Tectonophysics, 241, 193-224.

BERNARD, P. and A. Zollo (1989): The Irpinia (Italy) 1980 earthquake - detailed analysis of a complex normal faulting, J. Geophys. Res., 94 (B2), 1631-1647.

BiJWAARD, H. and W. SPAKMAN (2000): Non-linear global $P$-wave tomography by iterated linearized inversion, Geophys. J. Int., 141 (1),71-82

Blanco, M.J. and W. Spakman (1993): the $P$-wave velocity structure of the mantle below the Iberian Peninsula: evidence for subducted lithosphere below Southern Spain, Tectonophysics, 221, 13-34.

Blankenship, C.L. (1992): Structure and paleogeography of the External Betic Cordillera, Southern Spain, Mar. Petrol. Geol., 9, 256-264.

Bonardi, G., W. CAVAzZA, V. Perrone and S. Rossi (2001): Calabria-Peloritani terrane and Northern Ionian Sea, in Anatomy of a Mountain: the Apennines and Adjacent Mediterranean Basins, edited by G.B. VAI and I.P. Martini (Kluwer Academic Publisher, London), 287-306.

Bonini, M., G. Corti, D. Sokoutis, G. Vannucci, P. Gasperini and S. Cloetingh (2003): Insights from scaled analogue modelling into the seismitectonics of the Iranian region, Tectonophysics, 376, 137-149. 
Bordoni, P. and G. VAlENSISE (1998): Deformation of the 125 ka marine terrace in Italy: tectonic implecations, in Coastal Tectonics, edited by I.S. Stewart and C. Vita FinZI, Geol. Soc. London, Spec. Publ. 146, 71-110.

Bornovas, J. and Th. Rondogianni-Tsiambaou (1983): Geological Map of Greece, scale 1:500000 (Institute of Geology and Mineral Exploration, Athens).

BozKurT, E. (2001): Neotectonics of Turkey a synthesis, Geodin. Acta, 14, 3-30.

Braunmiller, J., U. KRADOLFER and D. Giardini (2002): Regional moment tensor determination in the European-Mediterranean area - initial results, Tectonophysics, 356, 5-22.

BuRCHFIEL, B.C. (1980): Eastern European Alpine system and the Carpathian orocline as an example of collision tectonics, Tectonophysics, 63, 31-61.

BurchFiel, B.C. and L.H. Royden (1991): Antler orogeny: a Mediterranean-type orogeny, Geology, 19, 66-69.

Burchfiel, C.B., R. Nakov, T. Tzankov and L.H. Royden (2000): Cenozoic extension in Bulgaria and northern Greece: the northern part of the Aegean extensional regime, in Tectonics and Magmatism in Turkey and the Surrounding Area, edited by E. BOZKURT, J.A. WinchESTER and J.D.A. PIPER, Geol. Soc. London, Spec. Publ. 173, 325-352.

Burke, K. and C. ŞENGÖR (1986): Tectonic escape in the evolution of the continental crust, in Reflection Seismology: the Continental Crust, edited by M. BArazAngi and L. Brown, Am. Geophys. Un., Geodyn. Ser., 14, 41-53.

Calvert, A., E. Sandvol, D. Seber, M. Barazangi, S. Roeker, T. Mourabit, F. Vidal, G. Alguacil and N. JABOUR (2000): Geodynamic evolution of the lithosphere and upper mantle beneath the Alboran region of the western Mediterranean: constraints from travel time tomography, J. Geophys. Res., 105, 10,971-10,898.

CAReY-Gailhardis, E. and J.L. Mercier (1992): Regional state of stress, fault kinematics and adjustments of blocks in a fractured body of rocks: application to the microseismicity of the Rhine Graben, J. Struct. Geol., 14, 1007-1017.

Carmignani, L. and R. Kligfield (1990): Crustal estension in the Northern Apennines: the transition from compression to extension in the Alpi Apuane core complex, Tectonics, 9, 12751303.

Casero, P., F. Roure, L. Endignoux, I. Moretti, C. Mueller, L. Sage and R. Vially (1988): Neogene geodynamic evolution of the Southern Apennines, Mem. Soc. Geol. It., 41, 109-120.

Catalano, R., P. Di Stefano and F.P. Vitale (1995): Structural trends and paleogeography of the Central and Western Sicily Belt: new insights, Terra Nova, 7, 189-199.

CElet, P. (1977): The Dinaric and Aegean arcs: the geology of the Adriatic, in The Ocean Basins and Margins, edited by A.E.M. NAiRn, W.H. KANES and F.G. STEHLi (Plenum Press), vol. 4A, 215-261.

Chaimov, T.A., M. Barazangi, D. Al-SaAd, T. Sawaf and A. Gebran (1992): Mesozoic and Cenozoic deformation inferred from seismic stratigraphy in the southwestern intracontinental Palmyride fold-and-thrust belt, Syria, Geol. Soc. Am. Bull., 104, 704-715.

Chalouan, A., A. Michard, H. Feinberg, R. Montigny and O. SaddiQi (2001): The Rif mountain building (Morocco): a new tectonic scenario, Bull. Soc. Geol. Fr., 172, 603-616.

ChanNELl, J.E.T. (1986): Palaeomoagnetism and continental collision in the Alpine Belt and the formation of late-tectonic extensional basins, in Continental Collision, edited by M.P. CowARD and A.C. Ries, Geol. Soc. London, Spec. Publ. 19, 261-284.

Channell, J.E.T., B. D’ Argenio and F. Horvath (1979): Adria, the African Promontory in Mesozoic Mediterranean paleogeography, Earth Sci. Rev., 15, 213-292.

Channell, J.E.T., J.S. Oldow, R. Catalano and B. D'Argenio (1990): Paleomagnetically determined rotations in the western Sicilian fold and thrust belt, Tectonics, 9, 641-660

Chaumillon, E. and J. Mascle (1995): Variation laterale des frontes de deformation de la Ride Mediterraneenne (Mediterranee Orientale), Bull. Soc. Geol. Fr., 166, 463-478. 
Chorowicz, J., D. Dhont and N. Gundogdu (1999): Neotectonics in the eastern North Anatolian fault region (Turkey) advocates crustal extension: mapping from SAR ERS imagery and digital elevation model, J. Struct. Geol., 21, 511-532.

Cianetti, S., P. Gasperini, M. Boccaletti and C. Giunchi (1997): Reproducing the velocity and stres field in the Aegean region, Geophys. Res. Lett., 24, 2087-2090.

Cianetti, S., P. Gasperini, C. Giunchi and E. Boschi (2001): Numerical modelling of the AegeanAnatolian region: geodynamical constraints from observed rheological heterogeneities, Geophys. J. Int., 146, 760-780.

Cinti, F., M. Moro, D. Pantosti, L. Cucci and G. D’Addezio (2001): New constraints on the seismic history of the Castrovillari Fault in the Pollino Gap (Calabria, Southern Italy), J. Seismol., 6, 199-217.

Cinti, F.R., L. Cucci, D. Pantosti, G. D’Addezio and M. Meghraoui (1997): A major seismogenic fault in a «silent area»: the Castrovillari Fault (Southern Apennines, Italy), Geophys. J. Int., 130, 322-332.

Colman-SADD, S.P. (1978): Fold development in Zagros simply folded belt, Southwest Iran, Am. Ass. Per. Geol. Bull., 62, 984-1003.

Comas, M.C., J.P. Platt, J.I. Soto and A.B. Watts (1999): The origin and tectonic history of the Alboran basin: Insights from leg 161 results, Proc. Ocean Drill. Program Sci. Results, 161, 555-579.

Courtillot, V., R. ArmiJo and P. TAPPOnNiER (1987): The Sinai triple junction revisited, Tectonophysics, 141, 181-190.

CowARD, M. and D. DiETRICh (1989): Alpine tectonics an overview, in Alpine Tectonics, edited by M. Coward, D. Dietrich and R. Park, Geol. Soc. London, Spec. Publ. 45, 1-29.

Cucci, L., G. D’Addezio, G. VAlensise and F. Burrato (1996): Investigating seismogenic faults in Central and Southern Apennines (Italy): modeling of fault-related landscape features, Ann. Geofis., XXXIX (3), 603-618.

Dal PiAZ, G.V. (1999): The Austroalpine-Piedmont nappe stack and the puzzle of Alpine Tethys, Mem. Sci. Geol., 51 (1), 155-176.

Dal PiAz, G.V. (2001): History of tectonic interpretations of the Alps, J. Geodyn., 32, 99-114.

De AlteriIs, G. (1995): Different foreland basins in Italy; examples from the central and southern Adriatic Sea, Tectonophysics, 252, 349-373.

De Astis, G., G. Ventura and G. Vilardo (2003): Geodynamic significance of the Aeolian volcanism (Southern Tyrrhenian Sea, Italy) in light of structural, seismological, and geochemical data, Tectonics, 22 (4), 1040, doi:10.1029/2003TC001506.

De Jonge, M.R., M.J.R. Wortel and W. Spakman (1994): Regional scale tectonic evolution and the seismic velocity structure of the lithosphere and upper mantle; the Mediterranean region, J. Geophys. Res., 99, 12091-12108.

Dercourt, J., L.P. Zonenshain, L.E. Ricou, V.G. Kazmin, X. Le Pichon, A.L. Knipper, C. Grandjacquet, I.M. Sbortshikov, J. Geyssant, C. Lepvrier, D.H. Pechersky, J. Boulin, J.C. Sibuet, L.A. Savostin, O. Sorokhtin, M. Westphal, M.L. Bazhenov, J.P. Lauer and B. Biju-Duval (1986): Geological evolution of the Tethys Belt from the Atlantic to the Pamirs since the Liassic, Tectonophysics, 123, 241-315.

DeMets, C., R.G. Gordon, D.F. Argus and S. Stein (1994): Effect of recent revisions to the geomagnetic time scale on estimates of current plate motion, Geophys. Res. Lett., 21, 2191-2194.

De Natale, G. and F. Pingue (1991): A variable slip fault model for the 1908 Messina Straits (Italy) earthquake, by inversion of leveling data, Geophys. J. Int., 104 (1), 73-84.

De Voogd, B., R. Nicolich, J.L. Olive, F. Fanucci, J. Burrus, A. Mauffret, G. Pascal, A. Argnani, J.M. Auzende, M. Bernabini, C. Bois, L. Carmignani, A. Fabbri, I. Finetti, A. Galdeano, C.Y. Gorini, P. Labaume, D. Lajat, P. Patriat, B. Pinet, J. Ravat, F. Ricci Lucchi and S. VERnASSA (1991): First deep seismic reflection transect from the Gulf of Lions to Sardinia (ECORS-CROP Profiles in Western Mediterranean), in Continental Lithosphere: Deep Seismic 
Reflections, edited by R. Meissner, L. Brown, H-J. Durbaum, W. Franke, K. Fuchs and F. SEIFERT, Am. Geophys. Un., Geodyn. Ser., 22, 265-274.

DewEY, J.F. (1980): Episodicity, sequence, and style at convergent plate boundaries, Geol. Assoc. Can. Spec. Pap. 20, 553-537.

DEWEY, J.F. (1988): Extensional collapse of orogens, Tectonics, 7, 1123-1139.

DewEY, J.F. and J.M. BIRD (1970): Mountain belts and the new global tectonics, J. Geophys. Res., 75, 2625-2647.

Dewey, J.F. and A.M.C. ŞENGÖR (1979): Aegean and surrounding regions: complex multiplate and continuum tectonics in a convergent zone, Geol. Soc. Am. Bull., 90, 84-92.

Dewey, J.F., W.C. Pitman III, W.B.F. Ryan and J. Bonnin (1973): Plate tectonics and the evolution of the Alpine system, Bull. Soc. Am. Bull., 84, 3137-3180.

Dewey, J.F., M.R. Hempton, W.S.F. KidD, F. SARoglu and A.M.C. ŞENGÖR (1986): Shortening of continental lithosphere: the neotectonics of Eastern Anatolia a young collision zone, in Collision Tectonics, edited by M.P. CowARD and A.C. RIES, Geol. Soc. London, Spec. Publ. 19, 3-36.

Dewey, J.F., M.L. Helman, E. Turco, D.H.W. Hutton and S.D. Knott (1989): Kinematics of the western Mediterranean, in Alpine Tectonics, edited by M.P. CowARD, D. DIETRICH and R.G. PARK, Geol. Soc. London, Spec. Publ. 45, 265-283.

Doglioni, C., F. Mongelli and G. Pialli (1998): Boudinage of the Alpine Belt in the Apenninic back-arc, Mem. Soc. Geol. It., 52, 457-468.

Doglioni, C., F. InNocenti and G. Mariotti (2001): Why Mt. Etna?, Terra Nova, 13, 25-31.

Duermeijer, C.E., M. Nyst, P.Th. Meijer, C.G. Langereis and V. Spakman (2000): Neogene evolution of the Aegean arc: paleomagnetic and geodetic evidence for a rapid and young rotation phase, Earth Planet. Sci. Lett., 176, 509-525.

Duggen, S., K. Hoernle, P. van den BogaArd and C. Harris (2004): Magmatic evolution of the Alboran region: the role of subduction in forming the Western Mediterranean and causing the Messinian Salinity Crisis, Earth Planet. Sci. Lett., 218, 91-108.

Dziewonski, A.M., T.A. Chou and J.H. Woodhouse (1981): Determination of earthquake source parameters from waveform data for studies of global and regional seismicity, J. Geophys. Res., 86, 2825-2852.

Dziewonski, A.M. and N.N. Maternovskaya (2000): Centroid-moment tensor solutions for October-December 1999, Phys. Earth Planet. Int., 121, 205-221.

EkströM, G. and P. ENGLAND (1989): Seismic strain rates in regions of distributed continental deformation, J. Geophys. Res., 94, 10231-10257.

Ekström, G.,A. Morelli, E. Boschi and A.M. DzIEwonski (1998): Moment tensor analysis of the central Italy earthquake sequence of September-October 1997, Geophys. Res. Lett., 25 (11), 19711974.

England, P. and J. JACKSON (1989): Active deformation of the continents, Ann. Rev. Earth Planet. Sci., 17, 197-226.

Faccenna, C.B., W. Thorsten, F.P. Lucente, L. Jolivet and F. Rossetti (2001): History of subduction and back-arc extension in the Central Mediterranean, Geophys. J. Int., 145 (3), 809-820. doi:10.1046/j.0956-540x.2001.01435.x.

Faccenna, C.B., L. Jolivet, C. Piromallo and A. Morelli (2003): Subduction and the depth of convection in the Mediterranean mantle, J. Geoph. Res., 108 (B2), doi: 10.1029/2002JB001690.

Faccenna, C.B., C. Piromallo, A. Crespo-Blanc and L. Jolivet (2004): Lateral slab deformation and the origin of the Western Mediterranean arcs, Tectonics, 23, TC1012, doi:10.1029/2002TC001488.

FAN, G., T.C. WALLACE and D. ZhaO (1998): Tomographic imaging of deep velocity structure beneath the Eastern and Southern Carpathians, Romania: implications for continental collision, J. Geophys. Res., 103, 2705-2723.

Frepoli, A. and A. Amato (1997): Contemporaneous extension and compression in the Northern Apennines from earthquake fault-plane solutions, Geophys. J. Int., 129, 368-388. 
Frepoli, A. and A. Amato (2000). Spatial variation in stresses in peninsular Italy and Sicily from background seismicity, Tectonophysics, 317 (1/2), 109-124.

Frizon de Lamotte, D., B. SAint Bezar and R. Bracene (2000): The two main steps of the Atlas building and geodynamics of the western Mediterranean, Tectonics, 19, 740-761.

Fytikas, M., F. Innocenti, P. Manetti, R. Mazzuoli, A. Peccerillo and L. Villari (1984): Tertiary to Quaternary evolution of volcanism in the Aegean region, in The Geological Evolution of the Eastern Mediterranean, edited by A.H.F. RoberTson and J.E. Dixon, Geol. Soc. London, Spec. Publ. 17, 687-699.

GAMBINI, R., R. ThOMAS and S. MORANDI (1997): FIST, Geoitalia 1997, 5-9 Ottobre 1997, Riassun$t i$, vol. 2, 170-171.

GARFUNKEL, Z. (1981): Internal structure of the Dead Sea leaky transform (rift) in relation to plate tectonics, Tectonophysics, 80, 81-108.

GatTACCECA, J. and F. SPERAnZA (2002): Paleomagnetism of Jurassic to Miocene sediments from the Apenninic carbonate platform (Southern Apennines, Italy); evidence for a 60 degrees counterclockwise Miocene rotation, Earth Planet. Sci. Lett., 201, 19-34.

GAUTIER, P. (2000): Comment on «Back arc extension and denudation of Mediterranean eclogites» by Dov Avigad, Zvi Garfunkel, Laurant Jolivet and Jose M. Azanon, Tectonics, 19, 406-409.

Gautier, P., J.-P. BRUN and L. Jolivet (1993): Structure and kinematics of Upper Cenozoic extensional detachment on Naxos and Paros (Cyclades Islands, Greece), Tectonics, 12, 1180-1194.

GEISS, E. (1987): A new compilation of crustal thickness data for the Mediteranean area, Ann. Geophysicae, 5B, 623-630.

Giamboni, M., K. Ustszewski, S.M. Schmid, M.E. Schemacher and A. Wetzel (2004): Plio-PLeistocene transpressional reactivation of Pleozoic and Paleogene structures in the Rhine-Bresse transform zone (Northern Switzerland and Eastern France), Int. J. Earth Sci., 93, 207-223.

Gomez, F., W. Beauchamp and M. Barazangi (2000): Role of the Atlas maountains (northwest Africa) within the African-Eurasian plate-boundary zone, Geology, 28, 775-778.

Gutscher, M.-A., J. Malod, J.P. Rehault, I. Contrucci, F. Klingelhoefer, L. Mendes-Victor and W. SPAKMAN (2002): Evidence for active subduction beneath Gibraltar, Geology, 30, 1071-1074.

Haas, J., P. Mioc, J. Pamič, B. Tomljenovic, P. Arkai, A. Berczi-Makk, B. Koroknai, S. Kovacs and E.R. Felgenhauer (2000): Complex structural pattern of the Alpine-Dinaridic-Pannonian triple junction, Int. J. Earth Sci., 89, 377-389.

Hatzfeld, D., V. Karakostas, M. Ziazia, G. Selvaggi, S. Leborgne, C. Berge, R. Guiguet, A. Paul, P. Voidomatis, D. Diagourtas, I. Kassaras, I. Koutsikos, K. Makropoulos, R. Azzara, M. Di Bona, M. Baccheschix, P. Bernard and C. Papaionnnou (1997): The Kozani-Grevena (Greece) Earthquake of 13 May 1995 revisited from a detailed seismological study, Bull. Seismol. Soc Am., 87 (2), 463-473.

Hayward, N., A.B. Watts, G.K. Westbrook and J.S. Collier (1999): A seismic reflection and GLORIA study of compressional deformation in the Gorringe Bank region, Eastern North Atlantic, Geophys. J. Int., 138, 831-850.

Hill, K.C. and A.B. HaYward (1988): Structural constraints on the Tertiary plate tectonic evolution of Italy, Mar. Pet. Geol., 5, 2-16.

Hippolyte, J.C., J. ANgElier and E. BARRIER (1995): Compressional and extensional tectonics in an arc system: example of the Southern Apennines, J. Struct. Geol., 17, 1725-1740.

Hollenstein, Ch., H.-G. Kahle, A. Geiger, S. Jenny, S. Goes and D. Giardini (2003): New GPS constraints on the Africa-Eurasia plate boundary zone in Southern Italy, Geophys. Res. Lett., 30 (18), 1935, doi:10.1029/2003GL017554.

Horvath, F. (1988): Neotectonic behaviour of the Alpine-Mediterranean region, in The Pannonian Basin, edited by L.H. Royden and F. HorvATH, AAPG Mem. 45, 49-55.

Horvath, F. and H. BercKHEMER (1982): Mediterranean Backarc Basins, in Alpine-Mediterranean Geodynamics, edited by H. BERCKHEMER and K. Hsu, Am. Geophys. Un., Geodyn. Ser., 7, 141-173. 
Houseman, G.A., D.P. McKenzie and P. Molnar (1981): Convective instability of a thickened boundary layer and its relevance for the thermal evolution of continental convergent belts, J. Geophys. Res., 86, 6115-6132.

Improta, L., A. Zollo, P.P. Bruno, A. Herrero and F. Villani (2003): High-resolution seismic tomography across the $1980\left(M_{s} 6.9\right)$ Southern Italy earthquake fault scarp, Geophys. Res. Lett., 30, 10.

ISC (InTERnational SeismologiCAl Centre) (2004): On-line bulletin (http://www.isc.ac.uk/), Bull. Int. Seismol. Cent. (Thatcham, U.K.).

JACKSON, J. (1994): Active tectonics of the Aegean Region, Ann. Rev. Earth Planet. Sci., 22, 239-271.

JACKSON, J. and T.J. FITCH (1981): Basement faulting and the focal depth of the larger earthquakes in the Zagros mountains (Iran), Geophys. J. R. Astron. Soc., 64, 561-586.

JACKSON, J. and D. MCKENZIE (1988): The relationship between plate motions and seismic moment tensors, and the rates of active deformation in the Mediterranean and Middle East, Geophys. $J$. Int., 93, 45-73.

KaGAN, Y.Y. (1991): 3D rotation of double-couple earthquakes sources, Geophys. J. Int., 106, 709-716.

Kahle, H.G., M. Cocard, Y. Peter, A. Geiger, R. Reilinger, A. Barka and G. Veis (2000): GPSderived strain rate field within the boundary zones of the Eurasian, African and Arabian plates, $J$. Geophys. Res., 105, 23,353-23,370.

Kastens, K., J. Mascle, C. Auroux and Coll. ODP Leg 107 Scientific Party (1988): ODP Leg 107 in the Tyrrhenian Sea: insights into passive margin and backarc basin evolution, Geol. Soc. Amer. Bull., 100, 1140-1156.

KASTENS, K.A. (1991): Rate of outward growth of the Mediterranean Ridge accretionary complex, Tectonophysics, 199, 25-50.

KESKIN, M. (2003): Magma generation by slab steepening and breakoff beneath a subduction-accretion complex: an alternative model for collision-related volcanism in Eastern Anatolia, Turkey, Geophys. Res. Lett., 30 (24), 8024, doi:10.1029/2003GL018019.

KLIGFIELD, R. (1979): The Northern Apennines as a collisional orogen, Am. J. Sci., 279, 676-691.

Kocyigit, A., H. Yusufoglu and E. BozkurT (1999): Evidence from the Gediz Graben for episodic two-stage extension in western Turkey, J. Geol. Soc. London, 156, 605-616.

Kocyigit, A., A. Yilmaz, S. Adamia and S. Kuloshvili (2001): Neotectonics of East Anatolia plateau (Turkey) and Less Caucasus: implication for transition from thrusting to strike-slip faulting, Geodyn. Acta, 14, 177-195.

Kopf, A., J. MASClE and D. KlAEschen (2003): The Mediterranean Ridge: a mass balance across the fastest growing accretionary complex on Earth, J. Geophys. Res., 108, 2372, doi:10.1029/ 2001JB000473.

Kostrov, V.V. (1974): Seismic moment and energy of earthquakes and seismic flow of rocks, Izv. Acad. Sci. USSR, Phys. Solid Earth, 1, 23-40.

Koukouvelas, J.K. and A. Aydin (2002): Fault structure and related basins of the North Aegean Sea and its surrounding, Tectonics, 21, 1046, doi:10.1029/2001TC901037.

Kurt, H., E. Demirbag and I. KusCu (1999): Investigation of the submarine active tectonism in the Gulf of Gokova, southwest Anatolia-southeast Aegean Sea, by multi-channel seismic reflection data, Tectonophysics, 305, 477-496.

LAWrence, S.R., V. TARI-KovACIC and B. GJUKIC (1995): Geological evolution model of the Dinarides, Nafta, 46, 103-113.

Le Pichon, X. and J. Angelier (1981): The Aegean Sea, Phil. Trans. R. Soc. London, Ser. A, 300, 357-372.

Le Pichon, X., F. Bergerat and M.J. Roulet (1988): Plate kinematics and tectonics leading to the Alpine Belt formation: a new analysis, Geol. Soc. Am., Spec. Pap. 218, 111-131.

Lickorish, W.H., M. Grasso, R.W.H. Butler, A. Argnani and R. Maniscalco (1999): Structural styles and regional tectonic setting of the «Gela Nappe» and frontal part of the Maghrebian thrust belt in Sicily, Tectonics, 18, 655-668. 
LinZER, H.-G. (1996). Kinematics of retreating subduction along the Carpathian arc, Romania, Geology, 24, 167-170.

Lister, G.S., G. BAnga and A. FeEnStra (1984): Metamorphic core complexes of Cordilleran type in the Cyclades, Aegean Sea, Greece, Geology, 12, 221-225.

Lonergan, L. and N. White (1997): Origin of the Betic-Rif Mountain Belt, Tectonics, 16, 504-522.

Lyberis, N. and G. MANBy (1999): Oblique to orthogonal convergence across the Turan Block in the post-Miocene, Am. Ass. Petr. Geol. Bull., 83, 1135-1160.

Macera, P., D. Gasperini, C. Piromallo, J. Blichert-Toft and D. Bosch (2003): Geodynamic implications of deep mantle upwelling in the source of Tertiary volcanics from the Veneto region (South-Eastern Alps), J. Geodyn., 36 (5), 563-590.

MAdEIRA, J. and A. RIBEIRo (1990): Geodynamic models for the Azores triple junction: a contribution from tectonics, Tectonophysics, 184, 405-415.

Makris, J. and C. Stobbe (1984): Physical properties and state of the crust and upper mantle of the eastern Mediterranean Sea deduced from geophysical data, Mar. Geol., 55, 347-363.

Malinverno, A. and W.B.F. Ryan (1986). Extension in the Tyrrhenian Sea and shortening in the Apennines as result of arc migration driven by sinking in the lithosphere, Tectonics, 5, 227245.

Mantovani, E., M. Viti, N. Cenni, D. Albarello and D. Babbucci (2001): Short and long term deformation patterns in the Aegean-Anatolian systems; insights from space geodetic data (GPS), Geophys. Res. Lett., 28 (12), 2325-2328.

Mantovani, E., D. Albarello, D. Babbucci and C. Tamburelli and M. Viti (2002): Trench-arcbackarc systems in the Mediterranean area: examples of extrusion tectonics, J. Virtual Explorer, 8, 125-141.

MARANI, M.P. and T. TRUA (2002): Thermal constriction and slab tearing at the origin of a superinflated spreading ridge: Marsili volcano (Tyrrhenian Sea), J. Geophys. Res., 107 (B9), 2188, 10.1029.

Mariucci, M.T., A. Amato and P. Montone (1999): Recent tectonic evolution and present stress in the Northern Apennines, Tectonics, 18, 108-118.

MARTINI, I.P. and M. SAGRI (1993): Tectono-sedimentary characteristics of late Miocene-Quaternary extensional basins of the Northern Apennines, Italy, Earth Sci. Rev., 34, 197-233.

Mascle, J. and E. Chaumillon (1997): Pre-collisional geodynamics of the Mediterranean Sea: the Mediterranean Ridge and the Tyrrhenian Sea, Ann. Geofis., XL (3), 569-586.

MAscle, J. and L. MARTin (1990): Shallow structure and recent evolution of the Aegean Sea: a synthesys based on continuous reflection profiles, Mar. Geol., 94, 271-299.

Mascle, J., J. Benkhelil, G. Bellaiche, T. Zitter, J. Woodside, L. Loncke and Prismed II ScienTIFIC PARTY (2000): Marine geologic evidence for a Levantine-Sinai plate, a new piece of the Mediterranean puzzle, Geology, 28, 779-782.

Mauritsch, H.J., R. Schloger, S.L. Bushati and H. Ramiz (1995): Palaeomagnetic results from southern Albania and their significance for the geodynamic evolution of the Dinarides, Albanides and Hellenides, Tectonophysics, 242, 5-18.

Maury, R.C., S. Fourcade, C. Coulon, M. El Azzouri, H. Bellon, A. Coutelle, A. Ouabadi, B. Semroud, M. Megartsi, J. Cotten, O. Belanteur, A. Louni-Hacini, A. Piquet, R. Capdevila, J. Hernandez and J.-P. Rehault (2000): Post-collisional Neogene magmatism of the Mediterranean Maghreb margin: a consequence of slab breakoff, C. R. Acad. Sci. Paris, Science de la Terre, 331, 159-173.

McClusky, S., S. Balassanian, A. Barka, C. Demir, S. Ergintav, I. Gerogiev, O. Gurkan, M. Hamburger, K. Hurst, H. Kahle, K. Kastens, G. Kekelidze, R. King, V. Kotzev, O. Lenk, S. Mahmoud, A. Mishin, M. Nadariya, A. Ouzounis, D. Paradissis, Y. Peter, M. Prilepin, R. Reilinger, I. Sanli, H. Seeger, A. Tealeb, M.N. Toksoz and G. Veis (2000): Global Positioning System constraints on plate kinematics and dynamics in the eastern Mediterranean and Caucasus, J. Geophys. Res., 105, 5695-5719. 
McClusky, S., R. Reilinger, S. Mahmoud, D. Ben Sari and A. Tealeb (2003): GPS contraints on Africa (Nubia) and Arabia plate motions, Geophys. J. Int., 155, 126-138.

McKenzIE, D.P. (1972): Active tectonics of the Mediterranean region, Geophys. J. R. Astron. Soc., 30, 109-185.

McKenzIE, D.P. (1977): Can Plate Tectonics describe continental deformation?, in Int. Symp. Struct. History Mediterr., edited by B. BiJu Duval and L. MONTADERT (Technip, Paris), 189-196.

McKenzIE, D.P. (1978): Active tectonics of the Alpine-Himalayan Belt: the Aegean Sea and surrounding regions, Geophys. J. R. Astron. Soc., 55, 217-254.

McQuARrie, N. (2004): Crustal scale geometry of the Zagros fold-thrust belt, Iran, J. Struct. Geol., 26, 519-535.

MeiJeR, P.Th. and M.J.R. Wortel (1997): Present-day dynamics of the Aegean region: a model analysis of the horizontal pattern of stress and deformation, Tectonics, 16, 879-895.

Mele, G. (1998): High-frequency wave propagation from mantle earthquakes in the Tyrrhenian Sea: new constraints for the geometry of the South Tyrrhenian subduction zone, Geophys. Res. Lett., 25, 2877-2880.

Menardi Noguera, A. and G. ReA (2000): Deep structure of the Campanian-Lucanian Arc (Southern Apennines, Italy), Tectonophysics, 266, 233-249.

Meulenkamp, J.E., M. Kovac and I. Cicha (1996): On Late Oligocene to Pliocene depocentre migrations and the evolution of the Carpathian-Pannonian system, Tectonophysics, 266, 301-317.

Montone, P., A. Amato and S. Pondrelli (1999): Active stress map of Italy, J. Geophys. Res., 104, 25,595-25,610.

Montone, P., M.T. MAriucci, S. Pondrelli and A. Amato (2004): An improved stress map for Italy and surrounding regions (Central Mediterranean), J. Geophys. Res. (in press).

MoretTI, I. and L. RoYDEn (1988): Delfection, gravity anomalies and tectonics of doubly subducted continental lithosphere: Adriatic and Ionian seas, Tectonics, 7, 875-893.

Mostardini, F. and S. Merlini (1986): Appennino centromeridionale. Sezioni geologiche e proposta di modello strutturale, Mem. Soc. Geol. It., 35, 177-202.

Muttoni, G., A. Argnani, N. Abrahamsen, U. Cibin and D. Kent (1998): Paleomagnetism of Cenozoic epiligurian units from the Northern Apennines, Italy, Earth Planet. Sci. Lett., 154, 25-40.

Muttoni, G., L. Lanci, A. Argnani, A.M. Hirt, U. Cibin, N. Abrahamsen and W. Lowrie (2000): Paleomagnetic evidence for a Neogene two-phase counterclockwise tectonic rotation in the Northern Apennines (Italy), Tectonophysics, 241, 241-253.

Muttoni, G., E. Garzanti, L. Alfonsi, S. Cirilli and D. Germani (2001): Motion of Africa and Adria since the Permian: paleomagnetic and paleoclimatic constraints from northern Libya, Earth Planet. Sci. Lett., 192, 159-174.

NATIONAL IRANIAN Oil COMPANy (1959): Geological Map of Iran, 1:2 500000, with Explanatory Notes.

Nemcok, M., L. Pospisil, J. LeXA and R.A. Donelick (1998): Tertiary subduction and slab break-off model of the Carpathian-Pannonian region, Tectonophys, 295, 307-340.

OKAY, A.I. and O. TUYSUZ (1999): Tethyan sutures of northern Turkey, in The Mediterranean Basins: Tertiary Extension within the Alpine Orogen, edited by B. Durand, L. Jolivet, F. Horvath and M. Seranne, Geol. Soc. London, Spec. Publ. 156, 475-515.

PAMIČ, J., B. TOMLJENOVIC and D. BALEN (2002): Geodynamic and petrogenetic evolution of Alpine ophiolites from the central and NW Dinarides: an overview, Lithos, 65, 113-142.

Pantosti, D., D.P. SchwartZ and G. VALENSISE (1993): Paleoseismology along the 1980 surface rupture of the Irpinia Fault - implications for earthquake recurrence in the Southern Apennines, Italy, J. Geophys. Res., 98 (B4), 6561.

Pascal, G., A. Mauffret and P. Patriat (1993): The ocean-continent boundary in the Gulf of Lion from analysis of expanding spread profiles and gravity modelling, Geophys. J. Int., 113, 712-726.

Patacca, E., R. SARTORI and P. Scandone (1990): Tyrrhenian Basin and Apenninic arcs. Kinematic relations since late Tortonian times, Mem. Soc. Geol. It., 45, 425-451. 
Patacca, E., P. Scandone and C. Meletti (1997): Variazioni di regime tettonico nell'Appennino meridionale durante il Quaternario, in AIQUA Annual Meeting Abstracts with Program, Parma.

Pieri, M. and G. GROPPI (1981): Subsurface geological structure of the Po Plain, Italy, Pubblication No. 414 (Progetto Finalizzato Geodinamica, CNR), pp. 13.

Piquet, A., P. Tricart, R. Guraud, E. Laville, S. Bouaziz, M. Amrhar and R. Ait Oulai (2002): The Mesozoic-Cenozoic Atlas Belt (North Africa): an overview, Geodin. Acta, 15, 185-208.

Piromallo, C. and C. Faccenna (2004): How deep can we find the traces of Alpine subduction?, Geophys. Res. Lett., 31, L06605, doi:10.1029/2003GL019288.

Piromallo, C. and A. Morelli (2003): $P$-wave tomography of the mantle under the Alpine-Mediterranean area, J. Geophys. Res., 108 (B2), doi: 10.1029/2002JB001757.

PLATT, J.P. and R.L.M. VisSER (1989): Extensional collapse of thickened continental lithosphere: a working hypothesis for the Alboran Sea and Gibraltar Arc, Geology, 17, 540-543.

Platt, J.P., S. Allerton, A. Kirker, C. Mandeville, A. Mayfield, E.S. Platzman and A. Rimi (2003): The ultimate arc: differential displacement, oroclinal bending, and vertical axis rotation in the External Betic-Rif Arc, Tectonics, 22, 1017, doi: 10.1029/2001TC001321.

Pondrelli, S. (1999): Pattern of seismic deformation in the Western Mediterranean, Ann. Geofis., 42 (1), 57-70.

Pondrelli, S., A. Morelli and E. Boschi (1995): Seismic deformation in the Mediterranean area estimated by moment tensor summation, Geophys. J. Int., 122, 938-952.

Pondrelli, S., A. Morelli, G. Ekström, S. MazzA, E. Boschi and A.M. Dziewonski (2002): European-Mediterranean regional centroid-moment tensors: 1997-2000, Phys. Earth Planet. Int., 130, 71-101.

Pondrelli, S., F. Di Luccio, E. Fukuyama, S. Mazza, M. Olivieri and N.A. Pino (2003): Fast determination of moment tensors for the recent Molise (Southern Italy) seismic sequence, ORFEUS Electron. Newsl., 5 (1), 2.

Pondrelli, S., A. Morelli and G. Ekström (2004a): European-Mediterranean regional Centroi Moment Tensor Catalog: solutions for the years 2001 and 2002, Phys. Earth Planet. Int. (in press).

Pondrelli, S., C. Piromallo and E. Serpelloni (2004b): Convergence versus retreat in Southern Tyrrhenian Sea: insights from kinematics, Geophys. Res. Lett., 31, L06611, doi:10.1029/ 2003 GL019223.

Ratschbacher, L., W. Frisch and H.-G. LinZER (1991): Lateral extrusion in the Eastern Alps, Part 2. Structural analysis, Tectonics, 10, 257-271.

Réhault, J.-P., G. Boillot and A. Mauffret (1984): The Western Mediterranean Basin geological evolution, Mar. Geol., 55, 447-477.

Ricci LuCCHI, F. (1986): The Oligocene to Recent foreland basins of the Northern Apennines, Spec. Publ. Int. Assoc. Sedimentologists, 8, 165-185.

RING, U. and P.W. LAYER (2003): High-pressure metamorphism in the Aegean, Eastern Mediterranean: underplating and exhumation from the Late Cretaceous until the Miocene to Recent above the retreating Hellenic subduction zone, Tectonics, 22, 1022, doi:10.1029/2001TC001350.

Ring, U., K. Gessner, T. Gungor and C.W. Passchier (1999): The Menderes Massif and the Cycladic Massif in the Aegean do they really correlate?, J. Geol. Soc. London, 156, 3-6.

RoberTSOn, A.H.F. (2002): Overview of the genesis and emplacement of Mesozoic ophiolites in the Eastern Mediterranean Tethyan region, Lithos, 65, 1-67.

Robertson, A.H.F., J.E. Dixon, S. Brown, A. Collins, A. Morris, E. Pickett, I. Sharp and T. UstaOMER (1996): Alternative tectonic models for the Late Palaeozoic-Early Tertiary development of Tethys in the Eastern Mediterranean region, in Palaeomagnetism and Tectonics of the Mediterranean Region, edited by A. Morris and D.H. TARLING, Geol. Soc. London Spec. Publ. 105, 239-263.

RoEDER, D. (1989): South-Alpine thrusting and trans-Alpine convergence, in Alpine Tectonics, edited by M. Coward, D. Dietrich and R. PArk, Geol. Soc. London Spec. Publ. 45, 211-227. 
Rossi, S. and R. SARTORI (1981): A seismic reflection study of the external Calabrian Arc in the N Ionian Sea (Eastern Mediterranean), Mar. Geophys. Res., 4, 403-426.

Roure, F., D.G. Howell, C. Mueller and I. Moretti (1990): Late Cenozoic subduction complex of Sicily, J. Struct. Geol., 22, 259-266.

Roure, R., P. Choukroune and R. Pollino (1996): Deep seismic reflection data and new insights on the bulk geometry of mountain ranges, C.R. Acad. Sci. Paris, Ser. IIa, 322, 345-359.

Royden, L. (1988): Late Cenozoic tectonics of the Pannonian Basin System, in The Pannonian Basin, edited by L.H. RoYden and F. HoRvaTh, AAPG Mem., 45, 27-48.

RoydEn, L. (1993a): The tectonic expression of slab pull at continental convergent boundaries, Tectonics, 12, 303-325.

RoydEN, L. (1993b): Evolution of retreating subduction boundaries formed during continental collision, Tectonics, 12, 629-638.

Royden, L. and B.C. BurChFiel (1989): Are systematic variations in thrust belt style related to plate boundary processes? (the Western Alps versus the Carpathians), Tectonics, 8, 51-61.

SARTori, R., L. Torelli, N. Zitellini, D. Peis and E. Lodolo (1994): Eastern segment of the AzoresGibraltar Line (Central-Eastern Atlantic): an oceanic plate boundary with diffuse compressional deformation, Geology, 22, 555-558.

Sawaf, T., G. Brew, R. LitaK and M. Barazangi (2001): Geologic evolution of the intraplate Plamyride Basin and Euphrates fault system, Syria, in PeriTethys Memoir 6: Rift/Wrench Basins and Passive Margins, edited by P. ZIEGLER, W. CAVAZZA, A.H.F.R. RoBERTSON and S. CRASQUINSoleau, Mem. Mus. Hist. Nat., 186, 441-467.

Schmid, S., A. Pfiffner, N. Froitzheim, G. Schoenborn and E. Kissling (1996): Geophysical-geological transect and tectonic evolution of the Swiss-Italian Alps, Tectonics, 15, 1036-1064.

SEARLE, R. (1980): Tectonic pattern of the Azores spreading centre and triple junction, Earth Planet. Sci. Lett., 51, 415-345.

Seber, D., M. Barazangi, A. Ibenbrahim and A. Demnati (1996): Geophysical evidence for lithospheric delaminantion beneath the Alboran Sea and Rif-Betic mountains, Nature, 379, 785-790.

SELla, G.F., T.H. DiXon and A. MaO (2002): REVEL: a model for Recent plate velocities from space geodesy, J. Geophys. Res., 107 (B4), 10.1029/2000JB000033.

SelvagGi, G. and A. Amato (1992): Subcrustal earthquakes in the Apennines (Italy): evidence for a still active subduction?, Geophys. Res. Lett., 19, 2127-2130.

ŞENGÖR, A.M.C. (1976): Collision of irregular continental margins: implications for foreland deformation of Alpine-typer orogens, Geology, 4, 779-782.

ŞENGÖR, A.M.C. and W.S.F. KIDD (1979): Post-collisional tectonics of the Turkish-Iranian plateau and a comparison with Tibet, Tectonophysics, 55, 361-376.

ŞEngÖR, A.M.C. and Y. YILMAZ (1981): Tethyan evolution of Turkey: a plate tectonic approach, Tectonophysics, $\mathbf{7 5}, 181-241$.

ŞENGÖR, A.M.C., S. OzEREN, T. GENC and E. ZoR (2003): East Anatolian high plateau as a mantle-supported, north-south shortened domal structure, Geophys. Res. Lett., 30 (24), 8045, doi:10.1029/ 1003GL017858.

Serpelloni, E., M. Anzidei, P. Baldi, G. Casula, A. Galvani, A. Pesci and F. Riguzzi (2002): Combination of permanent and non-permanent GPS networks for the evaluation of the strain-rate Field in the Central Mediterranean area, Boll. Geofis. Teor. Appl., 43, 195-219.

SondERS, L.J. and P.C. ENGLAND (1989): Effects of a temperature dependent rheology on large-scale continental extension, J. Geophys. Res., 94, 7603-7619.

Speranza, F., I. Islami, C. Kissel and A. Hyseni (1995): Paleomagnetic evidence for Cenozoic clockwise rotation of the external Albanides, EPSL, 129, 121-134.

Speranza, F., R. Maniscalco, M. Mattei, A. Di Stefano, R.W.H. Butler and R. Funiciello (1999): Timing and magnitude of rotations in the frontal thrust systems of southwestern Sicily, Tectonics, 18, 1178-1197. 
Steckler, M.S. and U.S. Ten Brinck (1985): Replacement of the Gulf of Suez by the Dead Sea transform: the role of old hinge zones in rifting, EOS, Trans. Am. Geophys. Un., 66, 364.

STECKLER, M.S. and U.S. TEN BRINCK (1986): Lithospheric strength variations as a control on new plate boundaries; examples from the northern Red Sea region. EPSL, 79, 120-132.

Stocklin, J. (1968): Structural history and tectonics of Iran: a review, Am. Ass. Pet. Geol. Bull., 52, 1229-1258.

TALEBIAN, M. and J. JACKSON (2004): A reappraisal of earthquake focal mechanisms and active shortening in the Zagros mountains of Iran, Geophys. J. Int., 156, 506-526.

TARI, V. and J. PAMIC (1998): Geodynamic evolution of the northern Dinarides and the southern part of the Pannonian Basin, Tectonophysics, 297, 269-281.

TirRUl, R., I.R. BELl, R.J. GRIFFIS and V.E. CAMP (1983): The Sistan suture of eastern Iran, Geol. Soc. Am. Bull., 94, 134-150.

Todesco, M. and L. Vigliotti (1993): When did the Sardinia rotates? Statistical avaluation of the paleomagnetic data, Ann. Geofis., XXXVI (5/6), 119-134.

Tortorici, L., C. Monaco, C. TAnsi and O. Cocina (1995): Recent and active tectonics in the Calabrian Arc (Southern Italy), Tectonophysics, 243, 37-55.

Trotet, F., L. Jolivet and O. VidAL (2001): Tectono-metamorphic evolution of Syros and Sifnos islands (Cyclades, Greece), Tectonophysics, 338, 179-206.

Truempy, R. (2001): Why plate tectonics was not invented in the Alps, Int. J. Earth Sci., 90, 477-483.

Turner, S. P., J.P. Platt, R.M. George, S.P. Kelley, D.G. Pearson and G.M. Nowell (1999): Magmatism associated with orogenic collapse of the Betic-Alboran Domain, SE Spain, J. Petrol., 40, 1011-1036.

UndeRHILl, J.R. (1989): Late Cenozoic deformation of the Hellenide foreland, Western Greece, Geol. Soc. Am. Bull., 101, 613-634.

VAlensise, G. and D. PANTOSTI (1992): A 125 kyr-long geological record of seismic source repeatability - the Messina Straits (Southern Italy) and the 1908 earthquake (m(s)), Terra Nova, 4, 472483.

VAlensise, G. and D. PANTOSTI (2001a): Seismogenic faulting, moment release patterns and seismic hazard along the Central and Southern Apennines and the Calabrian Arc, in Anatomy of a Mountain: the Apennines and Adjacent Mediterranean Basins, edited by G.B. VAI and I.P. MARTINI (Kluwer Academic Publisher, London), 495-512.

VAlensise, G. and D. PAnTosti (Editors) (2001b): Database of potential sources for earthquakes larger than M 5.5 in Italy, Ann. Geofis., 44 (suppl. to n. 4), pp. 175.

VANNUCCI, G. and P. GASPERINI (2003): A database of revised fault plane solutions for Italy and surrounding regions, Comput. Geosci., 29 (7), 903-909.

VAnNuCCI, G. and P. GASPERINI (2004): The new release of the database of Earthquake Mechanisms of the Mediterranean Area (EMMA Version 2), Ann. Geophysics, 47 (suppl. to n. 1), 307-334 (this volume).

Vidal, N, J. Alvarez-Marron and D. Klaeschen (2000): The structure of the Africa-Anatolia plate boundary in the Eastern Mediterranean, Tectonics, 19, 723-739.

Vigliotti, L. and V.E. LAngenheim (1995): When did Sardinia stop rotating? New palaeomagnetic results, Terra Nova, 7, 424-435.

VisSER, R.L.M., J.P. PlatT and D. VAN DER WAL (1995): Late orogenic extension of the Betic Cordillera and the Alboran domain: a lithospheric view, Tectonics, 14, 786-803.

Viti, M., D. Albarello and E. Mantovani (2001): Classification of seismic strain estimates in the Mediterranean region from a «bootstrap» approach, Geophys. J. Int., 146, 399-415.

von Blankenburg, F. and J.H., DAvies (1995): Slab breakoff: a model for syncollisional magmatism and tectonics in the Alps, Tectonics, 14, 120-131.

Watts, A.B., J.P. PlatT and P. Buhl (1993): Tectonic evolution of the Alboran Sea Basin, Besin Res., 5, 153-177. 
Wessel, P. and W.H.F. SMITH (1991): Free software helps map and display data, EOS, Trans. Am. Geophys. Un., 72, 441.

WESTAWAY, R. (1992): Seismic moment summation for historical earthquakes in Italy: tectonic implications, J. Geophys. Res., 97, 15437-15464.

WeStAWAY, R. (1993): Quaternary uplift of southern Italy, J. Geophys. Res., 97, 15,437-15,464.

WESTAWAY, R. and J. JACKSON (1987): The earthquakes of 1980 November 23 in Campania-Basilicata (Southern Italy), Geophys. J. R. Astron. Soc., 90, 375-443.

WILDI, W. (1983): La chaine tello-rifaine (Algerie, Maroc, Tunisia): structure, stratigraphie et evolution du Trias au Miocene, Rev. Geol. Dyn. Geogr. Phys., 24, 201-297.

WiLson, M. and H. Downes (1992): Mafic alkaline magmatism associated with the European Cenozoic Rift System, Tectonophysics, 208, 173-182.

Wortel, M.J.R. and W. Spakman (2000): Subduction and slab detachment in the MediterraneanCarpathian region, Science, 290, 1920-1917.

YILMAZ, Y. (1993): New evidence and model on the evolution of the southeast Anatolian orogen, Geol. Soc. Am. Bull., 105, 251-271.

ZECK, H.P. (1996): Betic-Rif orogen: subduction of Mesozoic Tethys lithosphere under eastward drifting Iberia, slab detachment shortly before $22 \mathrm{Ma}$, and subsequent uplift and extensional tectonics, Tectonophysics, 254, 1-16.

ZIEGLER, P. (1990): Collision related intra-plate compression deformation in western and central Europe, J. Geod., 11, 357-388.

ZiEgLeR, P. (1992): European Cenozoic Rift System, Tectonophysics, 208, 91-111.

Zitellini, N., M. Rovere, P. Terrinha, F. Chierici, L. Matias and BIGSET Team (2004): Neogene through Quaternary tectonic reactivation of SW Iberian passive margin, Pure Appl. Geophys., 161, 565-587.

ZS9 WORKING GROUP (2004): Redazione della mappa di pericolosità sismica prevista dall'Ordinanza PCM del 20 marzo 2003, in Rapporto Conclusivo per il Dipartimento della Protezione Civile, INGV, Milano-Roma, Aprile 2004, appendix 2 (available at http://zonesismiche.mi.ingv.it/). 